In cooperation with the California State Water Resources Control Board

\title{
Occurrence of Pesticides in Surface Water and Sediments from Three Central California Coastal Watersheds, 2008-09
}

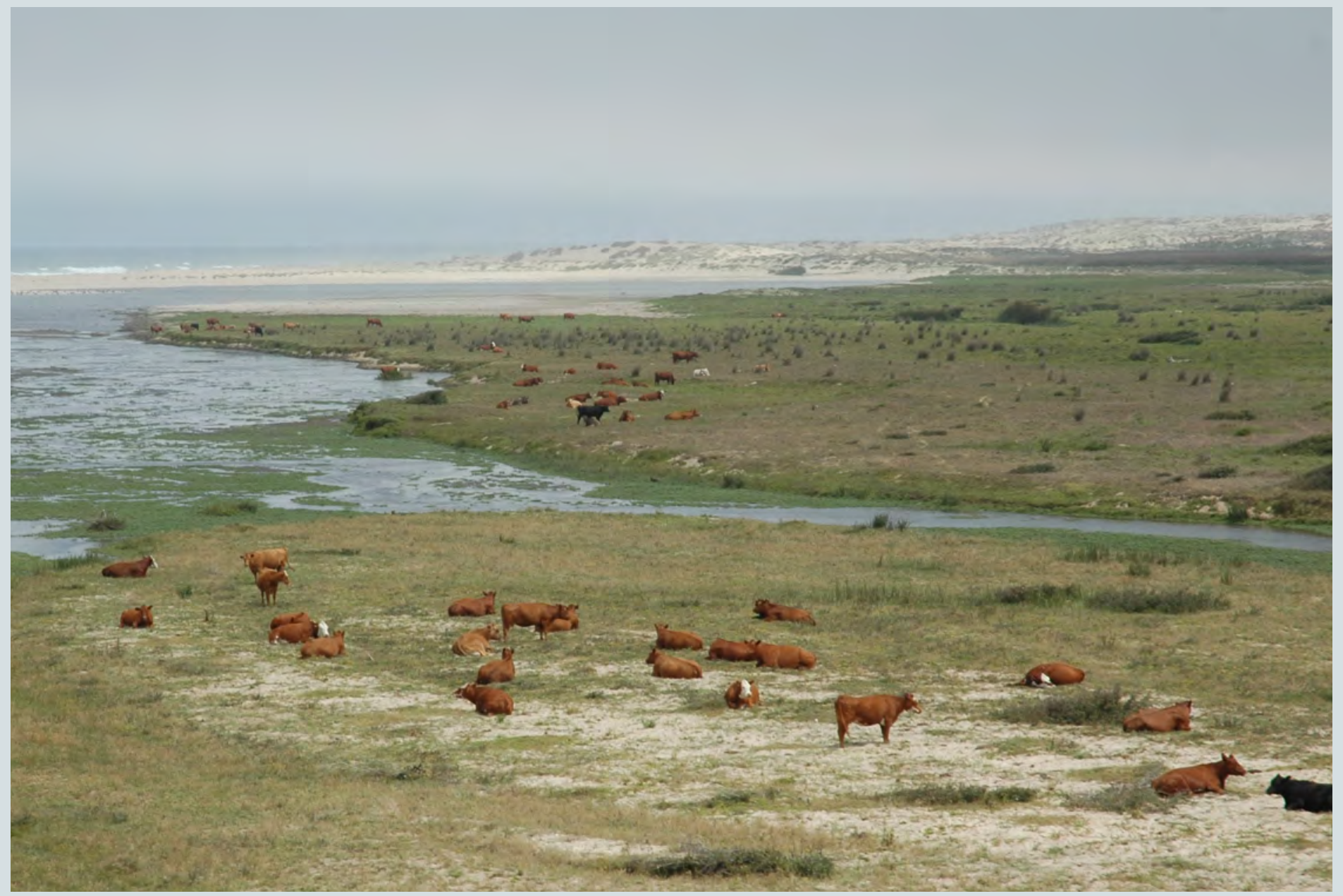

Data Series 600

U.S. Department of the Interior

U.S. Geological Survey 
Cover: Photo of the Santa Maria River estuary near Guadalupe, California.

Back: Photo of a drainage ditch adjacent to strawberry fields near Watsonville, California. 


\section{Occurrence of Pesticides in Surface Water and Sediments from Three Central California Coastal Watersheds, 2008-09}

By Kelly L. Smalling and James L. Orlando

Prepared in cooperation with the California State Water Resources Control Board

Data Series 600 


\title{
U.S. Department of the Interior \\ KEN SALAZAR, Secretary \\ U.S. Geological Survey \\ Marcia K. McNutt, Director
}

\author{
U.S. Geological Survey, Reston, Virginia: 2011
}

For more information on the USGS - the Federal source for science about the Earth, its natural and living resources, natural hazards, and the environment, visit http://www.usgs.gov or call 1-888-ASK-USGS.

For an overview of USGS information products, including maps, imagery, and publications, visit http://www.usgs.gov/pubprod

To order this and other USGS information products, visit http://store.usgs.gov

Any use of trade, product, or firm names is for descriptive purposes only and does not imply endorsement by the U.S. Government.

Although this report is in the public domain, permission must be secured from the individual copyright owners to reproduce any copyrighted materials contained within this report.

Suggested citation:

Smalling, K.L., and Orlando, J.L., 2011, Occurrence of pesticides in surface water and sediments from three central California coastal watersheds, 2008-09: U.S. Geological Survey Data Series 600, 70 p. 


\section{Contents}

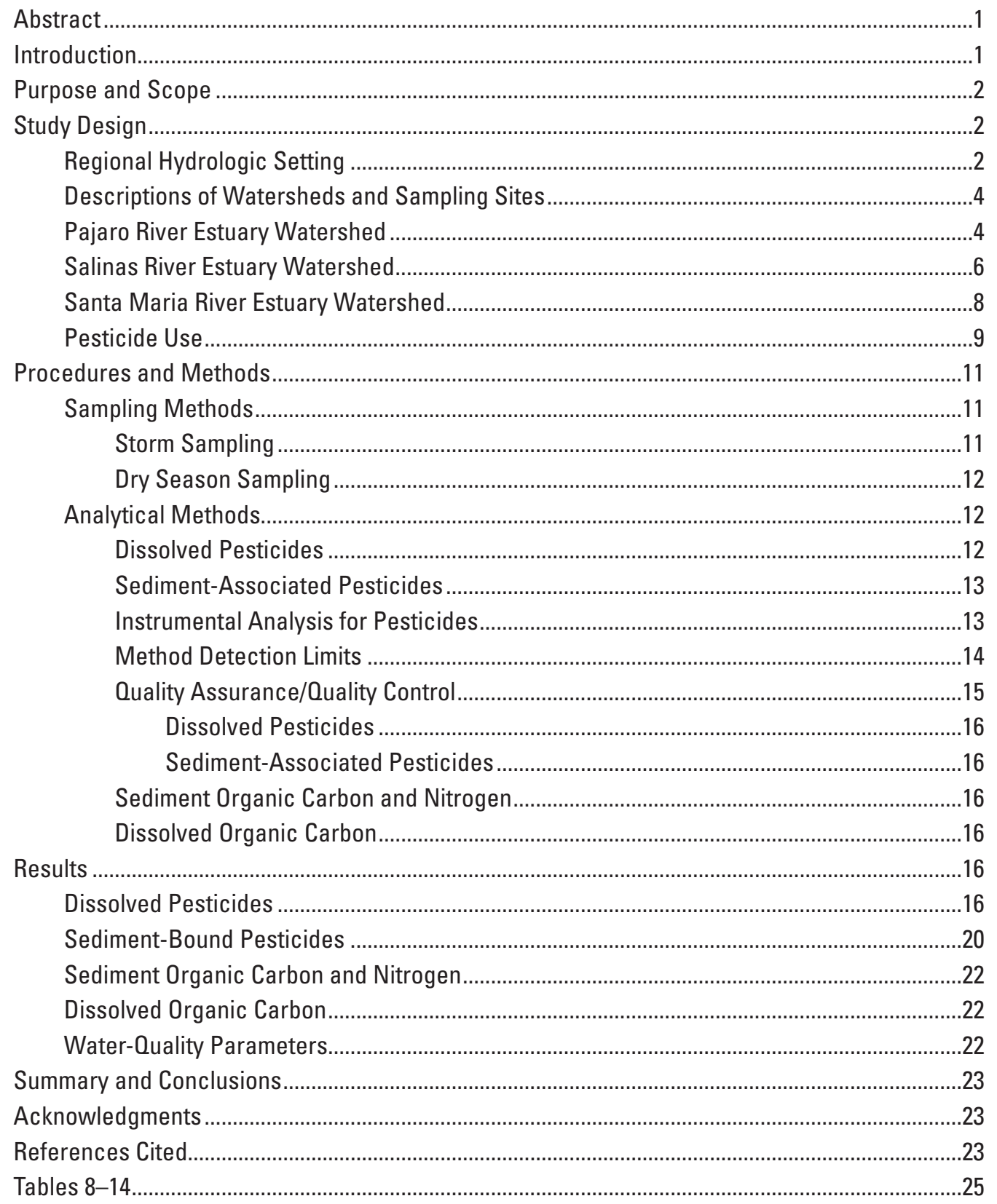




\section{Figures}

1. Map showing location of study area in the three central California coastal estuaries

2. Map showing aerial view of land cover and location of all sampling sites within the Pajaro River estuary watershed

3. Map showing aerial view of land cover and location of sampling sites within the Salinas River estuary watershed

4. Map showing aerial view of land cover and location of sampling sites within the Santa Maria River estuary watershed

5. Graph showing detection frequencies of dissolved pesticides, as a percentage of the total number of water samples by estuary.....

6. Graph showing detection frequencies of dissolved pesticides, as a percentage of the total number of samples by sampling period (storm versus dry) in the Pajaro, Salinas and Santa Maria River estuary watersheds, California, 2008-09.

7. Graph showing frequency of detection for pesticides in bed sediments, as a percentage of the total number of samples by estuary watershed, Pajaro, Salinas, and Santa Maria River estuary watersheds, California, 2008-09

8. Graph showing frequency of detection for the pesticides in suspended sediments, as a percentage of the total number of samples in each estuary watershed, Pajaro, Salinas, and Santa Maria River estuary watersheds, California, 2008-09

9. Graph showing frequency of detection of suspended sediment bound pesticides, as a percentage of the total number of samples by sampling period (storm versus dry season), Pajaro, Salinas, and Santa Maria River estuary watersheds, California, 2008-09 


\section{Tables}

1. Sampling sites located in the Pajaro, Salinas, and Santa Maria River estuary watersheds, California, 2008-09... . .4

2. Total watershed area and area by major land-use types for sites sampled during the study.

3. Top five crops by total weight of applied pesticides in the Pajaro, Salinas, and Santa Maria River estuary watersheds, California .10

4. Applications of pesticides analyzed during the study reported by land-use setting ......11

5. Method detection limits for dissolved pesticides in water .............................................14

6. Method detection limits for pesticides associated with bed and suspended sediments.

7. Maximum concentrations of dissolved pesticides by estuary and season (storm versus dry) in the Pajaro, Salinas, and Santa Maria River estuary watersheds, California, 2008-09

8. Dissolved pesticide and organic carbon concentrations measured in samples from the Pajaro River estuary watershed, California, 2008-09.

9. Dissolved pesticide and organic carbon concentrations measured in samples from the Salinas River estuary watershed, California, 2008-09.

10. Dissolved pesticide and organic carbon concentrations measured in samples from the Santa Maria River estuary watershed, California, 2008-09.

11. Bed sediment pesticides concentrations in samples from the major tributaries of the Pajaro, Salinas, and Santa Maria River estuary watersheds, California, 2008-09...54

12. Suspended sediment pesticides concentrations in samples from the Pajaro, Salinas, and Santa Maria River estuary watersheds, California, 2008-09.

13. Percent organic carbon and nitrogen in suspended and bed sediment samples from the tributary sites in the Pajaro, Salinas, and Santa Maria River estuary watersheds, California, 2008-09.

14. Discrete (single-point) and cross-sectional measurements for water-quality parameters at sampling sites in the Pajaro, Salinas, and Santa Maria River estuary watersheds, California, 2008-09 


\section{Conversion Factors}

SI to Inch/Pound

\begin{tabular}{lcl}
\hline \multicolumn{1}{c}{ Multiply } & \multicolumn{1}{c}{ By } & \multicolumn{1}{c}{ To obtain } \\
\hline centimeter $(\mathrm{cm})$ & Length & inch (in.) \\
millimeter $(\mathrm{mm})$ & 0.3937 & inch (in.) \\
meter $(\mathrm{m})$ & 0.03937 & foot (ft) \\
kilometer $(\mathrm{km})$ & 3.281 & mile (mi) \\
kilometer $(\mathrm{km})$ & 0.6214 & mile, nautical (nmi) \\
meter $(\mathrm{m})$ & 0.5400 & yard (yd) \\
\hline & 1.094 & square mile (mi $\left.{ }^{2}\right)$ \\
hectare $(\mathrm{ha})$ & Area & square mile (mi $\left.{ }^{2}\right)$ \\
square kilometer $\left(\mathrm{km}^{2}\right)$ & 0.003861 & quart (qt) \\
\hline liter $(\mathrm{L})$ & 0.3861 & gallon (gal) \\
liter $(\mathrm{L})$ & Volume & \\
\hline & 1.057 & cubic foot per second (ft $\left.{ }^{3} / \mathrm{s}\right)$ \\
\hline cubic meter per second $\left(\mathrm{m}^{3} / \mathrm{s}\right)$ & 0.2642 & pound avoirdupois $(\mathrm{lb})$ \\
\hline kilogram $(\mathrm{kg})$ & Flow rate & \\
\hline
\end{tabular}

Temperature in degrees Celsius $\left({ }^{\circ} \mathrm{C}\right)$ may be converted to degrees Fahrenheit $\left({ }^{\circ} \mathrm{F}\right)$ as follows:

$$
{ }^{\circ} \mathrm{F}=\left(1.8 \times{ }^{\circ} \mathrm{C}\right)+32
$$

Vertical coordinate information is referenced to North American Vertical Datum of 1988 (NAVD 88).

Horizontal coordinate information is referenced to the North American Datum of 1983 (NAD 83).

Altitude, as used in this report, refers to distance above the vertical datum.

Specific conductance is given in microsiemens per centimeter at 25 degrees Celsius $\left(\mu \mathrm{S} / \mathrm{cm}\right.$ at $\left.25^{\circ} \mathrm{C}\right)$.

Concentrations of chemical constituents in water are given either in milligrams per liter (mg/L), nanograms per liter ( $\mathrm{ng} / \mathrm{L}$ ) or micrograms per liter $(\mu \mathrm{g} / \mathrm{L})$. 


\section{Abbreviations}

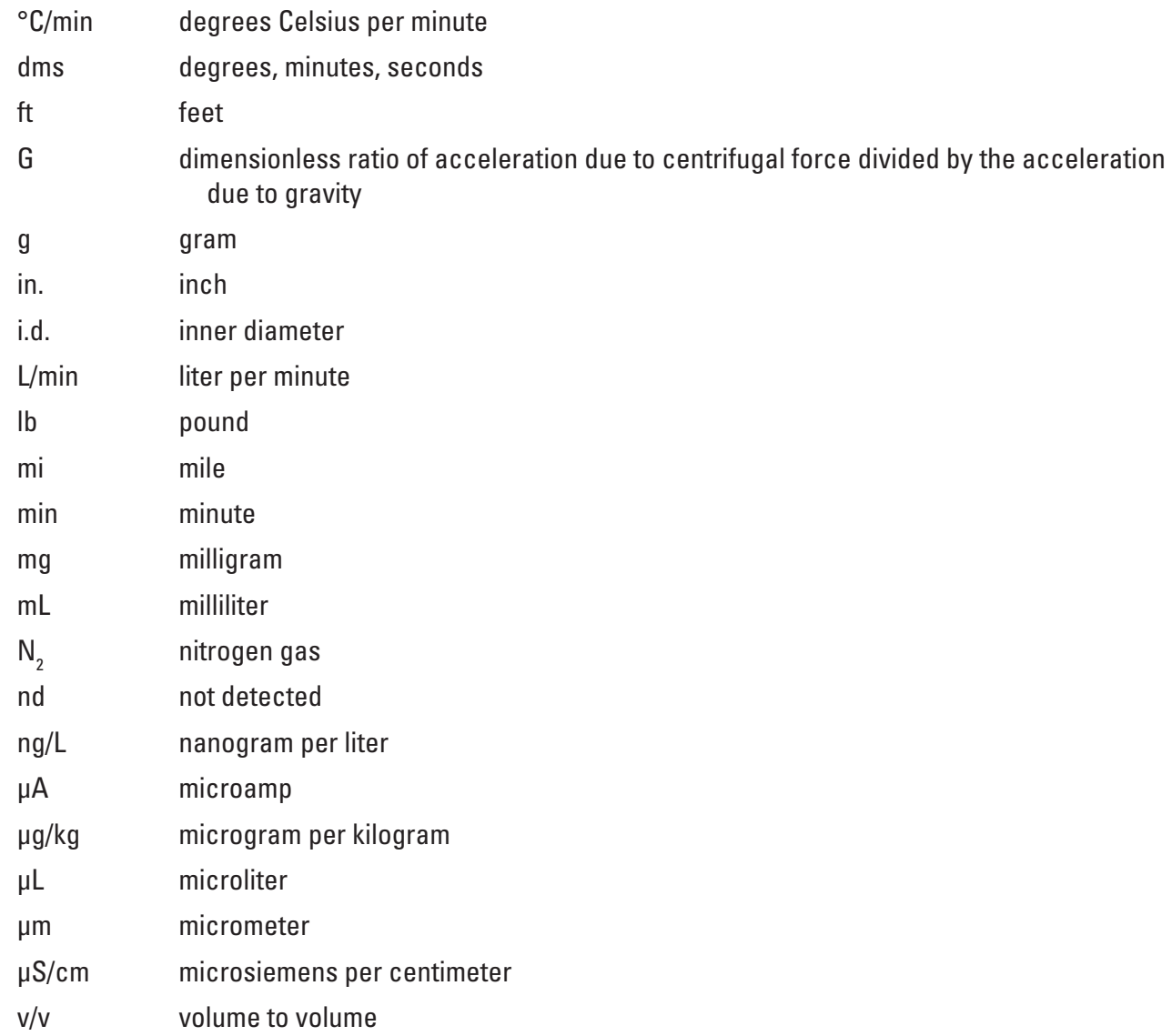

\section{Acronyms}

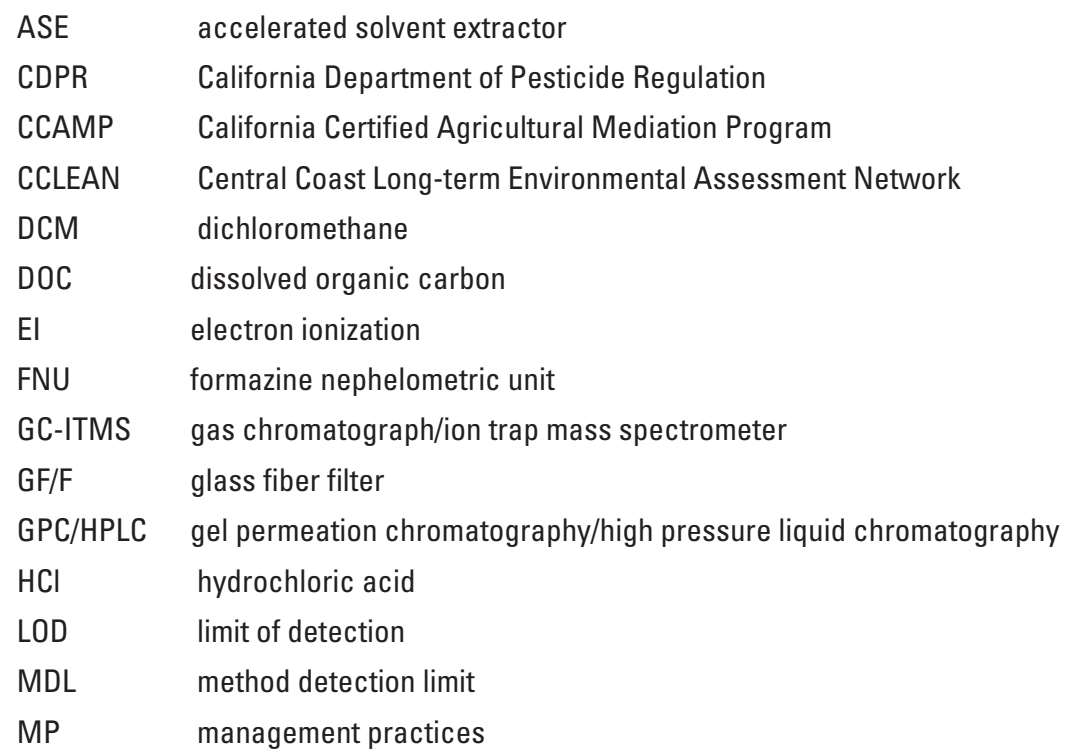




$\begin{array}{ll}\text { MS/MSD } & \text { matrix spike/matrix spike duplicate } \\ \text { OP } & \text { organophosphate pesticide } \\ \text { OCP } & \text { organochlorine pesticide } \\ \text { PAH } & \text { polycyclic aromatic hydrocarbon } \\ \text { PLE } & \text { pressurized liquid extraction } \\ \text { psi } & \text { pound per square inch } \\ \text { OA/QC } & \text { quality assurance/quality control } \\ \text { rpm } & \text { revolutions per minute } \\ \text { SPE } & \text { solid-phase extraction } \\ \text { SD } & \text { standard deviation } \\ \text { SIS } & \text { selective ion storage } \\ \text { SRM } & \text { standard reference material } \\ \text { SWAMP } & \text { Surface Water Ambient Monitoring Program } \\ \text { USEPA } & \text { U.S. Environmental Protection Agency } \\ \text { USGS } & \text { U.S. Geological Survey }\end{array}$




\title{
Occurrence of Pesticides in Surface Water and Sediments from Three Central California Coastal Watersheds, 2008-09
}

\author{
By Kelly L. Smalling and James L. Orlando
}

\begin{abstract}
Water and sediment (bed and suspended) were collected from January 2008 through October 2009 from 12 sites in 3 of the largest watersheds along California's Central Coast (Pajaro, Salinas, and Santa Maria Rivers) and analyzed for a suite of pesticides by the U.S. Geological Survey. Water samples were collected in each watershed from the estuaries and major tributaries during 4 storm events and 11 dry season sampling events in 2008 and 2009. Bed sediments were collected from depositional zones at the tributary sampling sites three times over the course of the study. Suspended sediment samples were collected from the major tributaries during the four storm events and in the tributaries and estuaries during three dry season sampling events in 2009.

Water samples were analyzed for 68 pesticides using gas chromatography/mass spectrometry. A total of 38 pesticides were detected in 144 water samples, and 13 pesticides were detected in more than half the samples collected over the course of the study. Dissolved pesticide concentrations ranged from below their method detection limits to 36,000 nanograms per liter (boscalid). The most frequently detected pesticides in water from all the watersheds were azoxystrobin, boscalid, chlorpyrifos, DCPA, diazinon, oxyfluorfen, prometryn, and propyzamide, which were found in more than 80 percent of the samples. On average, detection frequencies and concentrations were higher in samples collected during winter storm events compared to the summer dry season. With the exception of the fungicide, myclobutanil, the Santa Maria River estuary watershed exhibited higher pesticide detection frequencies than the Pajaro and Salinas watersheds.

Bed and suspended sediment samples were analyzed for 55 pesticides using accelerated solvent extraction, gel permeation chromatography for sulfur removal, and carbon/alumina stacked solid-phase extraction cartridges to remove interfering sediment matrices. In bed sediment samples, 17 pesticides were detected including pyrethroid and organophosphate (OP) insecticides, $p, p^{\prime}$-DDT and its
\end{abstract}

degradates, as well as several herbicides. The only pesticides detected more than half the time were $p, p^{\prime}$-DDD, $p, p^{\prime}$-DDE, and $p, p^{\prime}$-DDT. Maximum pesticide concentrations ranged from less than their respective method detection limits to 234 micrograms per kilogram ( $p, p^{\prime}$-DDE). Four pyrethroids (bifenthrin, $\lambda$-cyhalothrin, permethrin, and $\tau$-fluvalinate) were detected in bed sediment samples, though concentrations were relatively low (less than 10 microgram per kilogram). The greatest number of pesticides were detected in samples collected from Lower Orcutt Creek, the major tributary to the Santa Maria River estuary. In suspended sediment samples, 19 pesticides were detected, and maximum concentrations ranged from less than the method detection limits to 549 micrograms per kilogram (chlorpyrifos). The most frequently detected pesticides were $p, p^{\prime}$-DDE (49 percent), $p, p^{\prime}$-DDT (38 percent), and chlorpyrifos (32 percent). During storm events, 19 pesticides were detected in suspended sediment samples compared to 10 detected during the dry season. Pesticide concentrations commonly were higher in suspended sediments during storm events than during the dry season, as well.

\section{Introduction}

Coastal estuaries are among the most ecologically important and critically threatened habitats in California. Less than 20 percent of the State's coastal wetlands remain, and many of these face threats from water-quality degradation. Along California's central coast, rivers in the three largest watersheds (the Pajaro, Salinas, and Santa Maria) drain to coastal estuaries that provide essential habitat for commercially and recreationally important marine fish species, threatened anadromous fish species, migratory birds, and other wildlife. These estuaries provide a number of beneficial uses, such as recreation and activities related to many fisheries, including spawning and salmonid migration corridors, and are biological habitats of special significance for a variety of rare, threatened, and endangered species. 
Each of these watersheds contains year-round, intensively cultivated agricultural land that supports a $\$ 3.5$ billion/ year industry, producing much of the nation's lettuce, artichokes, and crucifer crops (California Department of Pesticide Regulation, 2009). Runoff from irrigated agriculture constitutes a significant portion of river flow during most of the year. Studies have documented pesticide occurrence and biological effects from pesticides in the rivers and estuaries of the Pajaro (Hunt and others, 1999), Salinas (Anderson and others, 2003), and Santa Maria (Anderson and others, 2006).

Evidence of pesticide impacts has encouraged a number of diverse stakeholders to begin implementing farm management practices (MPs) to reduce pesticide concentrations and toxicity in agricultural runoff. Over the past decade, a variety of organizations, including farm watershed groups, the California Central Coast Regional Water Quality Control Board's Agricultural Waiver Program, the Monterey Bay National Marine Sanctuary Water Quality Protection Program, and the Resource Conservation Districts, have been working together to identify water-quality problems and to evaluate the effectiveness of individual farm-scale MPs to mitigate pesticide runoff. As the MPs begin to be used more widely, the next step likely will be to evaluate the effectiveness of MP implementation on a watershed-scale.

None of the monitoring programs in the region, including the Surface Water Ambient Monitoring Program (SWAMP), the Certified Agricultural Mediation Program (CCAMP), the Central Coast Long-term Environmental Assessment Network (CCLEAN), or Agricultural Waiver Monitoring, target the critical coastal estuaries that receive surface runoff from these large agricultural watersheds. This project is primarily designed to measure the current concentration of pesticides in these critical estuarine habitats. This information on concentrations of contaminants and exposure of biota to contaminants can be used as a baseline for future evaluations of watershed-scale effectiveness of agricultural MP implementation.

\section{Purpose and Scope}

This report describes the methods and procedures used to determine pesticide concentrations in 144 water and 90 sediment-bound samples collected from five sites in the Pajaro watershed, four sites in the Salinas watershed, and three sites in the Santa Maria watershed during 2008 and 2009. Water and sediment were analyzed for a suite of 68 and 55 pesticides, respectively. Concentrations of dissolved organic carbon and particulate organic carbon and nitrogen in bed sediment are also presented. Details of the analytical methods including appropriate citations are included.

Specifically for this study, five new pesticides were added to surface water methods and two new pesticides were added to sediment methods. Information on these new pesticides is included in the tables.

\section{Study Design}

The objective of this project was to establish baseline pesticide concentrations in each estuary where MPs are being implemented to assist in detection of changes in pesticide concentrations over the next 2 decades as MPs change. The specific goals for this project were to measure currentuse and legacy pesticide concentrations in the water, bed sediment, and suspended sediments in the estuaries and several major tributaries to each estuary. The primary focus was on the estuaries, but the tributaries were also sampled in close proximity to the estuaries to determine the types and concentrations of pesticides entering the estuary during storms and during pesticide applications. The two specific project objectives were (1) to measure the concentrations of pesticides in the water and sediment and (2) to qualitatively compare the suites of pesticides detected in the estuaries with those found in key adjacent tributaries that convey agricultural runoff into the estuaries.

\section{Regional Hydrologic Setting}

Three intensively farmed watersheds along California's Central Coast (the Pajaro, Salinas, and Santa Maria River estuary watersheds), extending from Monterey Bay in the north to near Point Conception in the South, were sampled during this study (fig. 1 ). The central coast landscape is characterized by a rugged coastline, relatively low mountain ranges parallel to the coast, and linear river valleys. Each watershed drains mountainous areas in California's Coast Range as well as valley agricultural lands extending to the coast. The watersheds are drained by single mainstem rivers that empty into small coastal estuaries. Flows in the mainstem rivers are highly variable, and lower reaches of all three rivers can be dry or ponded for part of the year. Tributaries that enter the lowest reaches of the rivers function essentially as agricultural drains. Also, all three estuaries are closed to the ocean by natural sand dunes periodically, though there is some exchange of water through the dunes. During much of the year these tributaries are the primary sources of fresh water to the estuaries.

The three watersheds share a Mediterranean climate, typified by warm to hot, dry summers and mild, wet winters. Temperatures are typically cooler near the coast (at least $10^{\circ} \mathrm{C}$ ) and warmer inland, with onshore winds throughout much of the year. Average annual rainfall amounts are highest along the coast (18-40 in.), and decrease inland (4.5-12 in.). Most precipitation falls from January to March and coastal fog occurs in summer. In the more southerly Santa Maria watershed, mean annual temperatures are a few degrees higher and mean annual precipitation is slightly lower than in the Pajaro and Salinas watersheds, though the timing of precipitation is the same. 


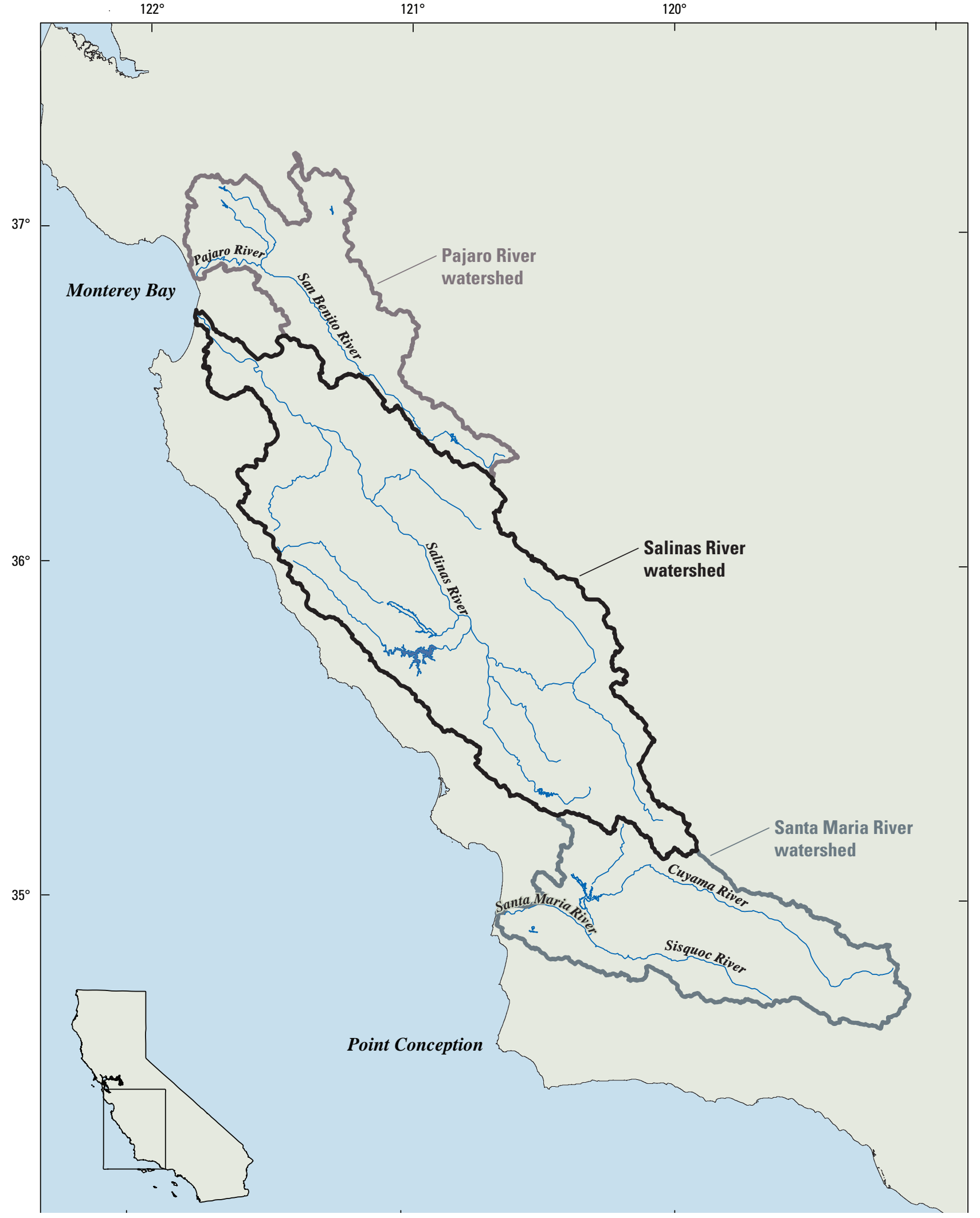

Figure 1. Location of study area in the three central California coastal estuaries. 


\section{Descriptions of Watersheds and Sampling Sites}

Samples were collected from sites within the Pajaro, Salinas, and Santa Maria estuaries as well as from the major tributaries draining agricultural lands upstream of the estuaries. Within each estuary, water and bed sediment samples were collected from one station located near the estuary mouth and another station located at the upstream end of the estuary along the mainstem river channel. These "lower" and "upper" sites receive water from the upstream river/tributary watersheds as well as from lands not within these watersheds. Each river/tributary site was located as close to its confluence with the estuary as feasible (figs. 2-4), and represents a distinct watershed (table 1). Watersheds were delineated using ArcGIS Desktop GIS software (Environmental Systems Research Institute, Redlands, CA). Initial watershed boundaries were taken from a preexisting dataset of national watershed boundaries (Natural Resources Conservation Service, 2009). The boundaries were then modified by digitizing the boundaries using high-resolution aerial photographs and detailed hydrography as a backdrop and matched to specific sampling sites.

Table 1. Sampling sites located in the Pajaro, Salinas, and Santa Maria River estuary watersheds, California, $2008-09$.

[Horizontal datum: North American Datum 83 (NAD 83); vertical datum: North American Vertical Datum of 1988 (NAVD 88). Abbreviations: USGS, U.S. Geological Survey]

\begin{tabular}{|c|c|c|c|c|}
\hline USGS station number & USGS station name & Common station name & Latitude & Longitude \\
\hline 365159121480801 & $\begin{array}{l}\text { Monterey drainage ditch near Watson- } \\
\text { ville }\end{array}$ & Monterey drainage ditch & 36.86650 & -121.80225 \\
\hline 365200121485901 & Watsonville Slough near Watsonville & Watsonville Slough & 36.86680 & -121.81656 \\
\hline 365247121473301 & $\begin{array}{l}\text { Pajaro River below Thurwachter Road } \\
\text { near Watsonville }\end{array}$ & Pajaro River below Thurwachter & 36.87968 & -121.79356 \\
\hline 365140121480101 & Pajaro River estuary near Watsonville & Pajaro River estuary upper & 36.86111 & -121.80028 \\
\hline 364154121440501 & Blanco drain near Marina & Blanco drain & 36.69858 & -121.73494 \\
\hline 363848121420801 & $\begin{array}{l}\text { Salinas River at Davis Road near } \\
\text { Salinas }\end{array}$ & Salinas River at Davis Road & 36.64676 & -121.70222 \\
\hline 364355121465601 & Salinas River estuary near Castroville & Salinas River estuary upper & 36.73194 & -121.78222 \\
\hline 345742120384701 & $\begin{array}{l}\text { Santa Maria River estuary near Gua- } \\
\text { dalupe }\end{array}$ & Santa Maria River estuary upper & 34.96167 & -120.64639 \\
\hline 345811120385801 & $\begin{array}{l}\text { Santa Maria River estuary at mouth } \\
\text { near Guadalupe }\end{array}$ & Santa Maria River estuary lower & 34.96972 & -120.64944 \\
\hline
\end{tabular}

\section{Pajaro River Estuary Watershed}

The Pajaro River estuary watershed drains approximately 1,300 square miles $\left(\mathrm{mi}^{2}\right)$ and includes 76,400 acres in agriculture (U.S. Geological Survey, 2001; table 2). Elevations within the watershed range from sea level to approximately $5,200 \mathrm{ft}$ above sea level. The Pajaro River forms the border between Santa Cruz and Monterey Counties. Agriculture in the lower Pajaro River estuary watershed is concentrated near the cities of Watsonville, Aromas, and Pajaro. The main tributaries to the lower river and estuary include Corralitos and Salsipuedes Creeks, Watsonville Slough, and agricultural discharges from the Beach Street ditch and the Monterey drainage ditch. In the lower Pajaro River and adjacent Watsonville Slough watersheds, several water bodies are currently listed as impaired by pesticides under the Clean Water Act 303(d), including Watsonville Slough and the lower Pajaro River (State Water Resources Control Board, 2002). 
The Pajaro River estuary is narrow with manmade levees along nearly its entire length (fig. 2). A large sand spit forms the estuary's western boundary and completely cuts the estuary off from the sea under low-flow conditions, which primarily occur during the spring and summer. Water and sediment samples were collected from a site along the sand spit near the estuary mouth (Pajaro River estuary lower) and a second site located approximately 1 mile upstream (Pajaro River estuary upper). Three sub-watersheds were sampled within the Pajaro River estuary watershed: Monterey drainage ditch, Watsonville Slough, and Pajaro River below Thurwatcher Road (fig. 2).

The Thurwatcher Road site is located $1.5 \mathrm{mi}$ upstream from the sampling site at the upper end of the Pajaro River estuary and $1.1 \mathrm{mi}$ upstream of the Monterey drainage ditch outfall (fig. 2). Depending on flow conditions, this site can be tidally affected. This site represents the largest tributary watershed $\left(1,270 \mathrm{mi}^{2}\right)$ sampled in the Pajaro River estuary system (table 2). Approximately 70,000 acres in this subwatershed are devoted to agriculture and 26,000 acres are primarily urban, representing 8.6 and 3.2 percent of the total sub-watershed area, respectively (table 2).

The Watsonville Slough sampling site is located $1.4 \mathrm{mi}$ upstream from the lower Pajaro River estuary site, and is immediately downstream of the confluence with the Beach Street Drain, a major agricultural drain. When the estuary is open to the sea, this site experiences a wide tidal range and flow reversal. The watershed upstream of this site is about $23.4 \mathrm{mi}^{2}$ in size with 3,399 acres in agriculture and 4,260 acres of urban land use (table 2).

The smallest tributary watershed sampled was Monterey drainage ditch $\left(4.0 \mathrm{mi}^{2}\right)$. The sampling site for this watershed is located at a culvert passing through the landward side of the levee separating the Pajaro River estuary from adjacent farmland. A flap gate on the estuary side of the levee prevents water from flowing into the Monterey drainage ditch from the estuary at high tide. This sub-watershed is predominantly agricultural, with 1,634 acres, or 64 percent, of the total watershed area farmed, whereas, 258 acres, or 10.1 percent, are urban land.

Table 2. Total watershed area and area by major land-use types for sites sampled during the study.

[The three estuary sites represent both the upper and lower estuary sites. Land use data from National Land Cover Database (U.S. Geological Survey, MultiResolution Land Characteristics Consortium, 2001). Abbreviations: $\mathrm{mi}^{2}$, square miles]

\begin{tabular}{|c|c|c|c|c|c|c|c|}
\hline Watershed & $\begin{array}{c}\text { Watershed } \\
\text { area } \\
\left(\mathrm{mi}^{2}\right)\end{array}$ & $\begin{array}{l}\text { Urban } \\
\text { land use } \\
\text { (acres) }\end{array}$ & $\begin{array}{c}\text { Percent- } \\
\text { age of total } \\
\text { watershed }\end{array}$ & $\begin{array}{l}\text { Agricultural } \\
\text { land use } \\
\text { (acres) }\end{array}$ & $\begin{array}{l}\text { Percent- } \\
\text { age of total } \\
\text { watershed }\end{array}$ & $\begin{array}{l}\text { Undeveloped } \\
\text { land use } \\
\text { (acres) }\end{array}$ & $\begin{array}{c}\text { Percent- } \\
\text { age of total } \\
\text { watershed }\end{array}$ \\
\hline Monterey drainage ditch & 4.0 & 258 & 10.1 & 1,634 & 64.0 & 662 & 25.9 \\
\hline Watsonville Slough & 23.4 & 4,260 & 28.5 & 3,399 & 22.7 & 7,303 & 48.8 \\
\hline $\begin{array}{l}\text { Pajaro River below } \\
\text { Thurwachter Road }\end{array}$ & $1,270.4$ & 26,214 & 3.2 & 70,153 & 8.6 & 716,659 & 88.1 \\
\hline Blanco drain & 7.7 & 120 & 2.4 & 4,568 & 92.2 & 265 & 5.3 \\
\hline Salinas River at Davis Road & $4,210.0$ & 22,124 & 0.8 & 223,793 & 8.3 & $2,448,485$ & 90.9 \\
\hline $\begin{array}{l}\text { Salinas River estuary } \\
\text { (upper and lower) }\end{array}$ & $4,234.8$ & 23,291 & 0.9 & 232,995 & 8.6 & $2,454,011$ & 90.5 \\
\hline $\begin{array}{l}\text { Santa Maria River estuary } \\
\text { (upper and lower) }\end{array}$ & $1,827.7$ & 13,437 & 1.1 & 85,941 & 7.3 & $1,070,384$ & 91.5 \\
\hline
\end{tabular}



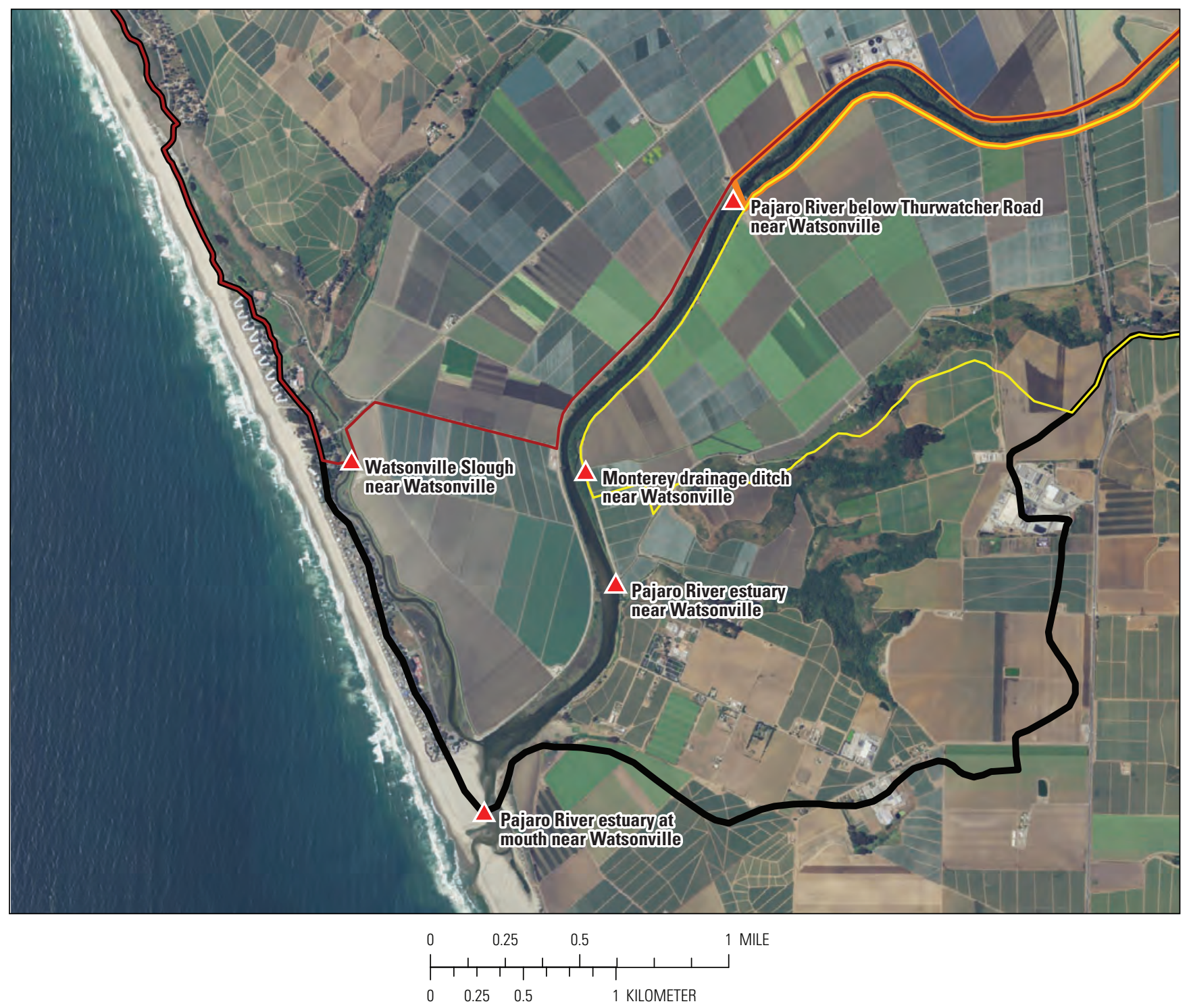

EXPLANATION

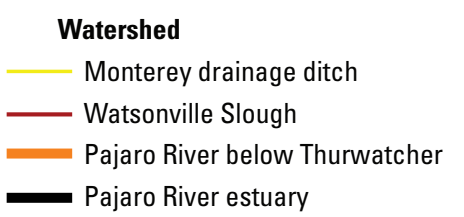

A Sampling site

Figure 2. Aerial view of land cover and location of all sampling sites within the Pajaro River estuary watershed.

\section{Salinas River Estuary Watershed}

The Salinas River flows over 150 miles from its headwaters in San Luis Obispo County through the Salinas Valley, and enters the Monterey Bay National Marine Sanctuary at the Salinas River National Wildlife Refuge. The Salinas River Estuary watershed is the largest on the California Central Coast at just over 4,230 $\mathrm{mi}^{2}$. The watershed contains nearly 233,000 acres of year-round, intensively cultivated agricultural land producing much of the nation's salad greens, artichokes, and crucifer crops. In the Salinas River estuary watershed, multiple water bodies are currently listed as impaired by pesticides under Clean Water Act 303(d), including Blanco drain, Chualar and Quail Creeks, the lower and middle Salinas River, Salinas Lagoon, and Tembladero Slough (State Resources Water Control Board, 2002). The Salinas River estuary is long and narrow in shape, though wider than the Pajaro River estuary, and extends roughly from Highway 1 to the sea, where it is blocked by a wide sand spit (fig. 3). The lower estuary site (Salinas River estuary lower) 
is located immediately landward of the sand spit, whereas the upper estuary site (Salinas River estuary upper) is located at the Highway 1 crossing, $1.7 \mathrm{mi}$ upstream. Lower sections of the estuary are not leveed and the area landward of the sand spit contains a large lagoon and wetlands. Two river/tributary sites were sampled within the larger Salinas watershed.

Samples were collected from the Salinas River at the Davis Road Bridge, located approximately 8.9 river miles upstream of the upper estuary sampling site. The Davis Road Bridge is well upstream of any tidal influence, and during the summer and fall months it typically has very little flow. The watershed for this site is approximately $4,210 \mathrm{mi}^{2}$ with almost
223,800 acres of agricultural land and about 22,000 acres of urban development.

Samples were collected from Blanco drain, a major agricultural drain which receives field runoff from lands north of the Salinas River. The Blanco drain site was located at a culvert crossing Cooper Road in an area of intensive agriculture (fig. 3). Blanco drain empties into the Salinas River approximaely $1.3 \mathrm{mi}$ downstream from the sampling site. The Blanco drain watershed, at $7.7 \mathrm{mi}^{2,}$ was the second smallest watershed sampled during the study, and had the most agricultural land, with over 92 percent of the total watershed area (table 2).
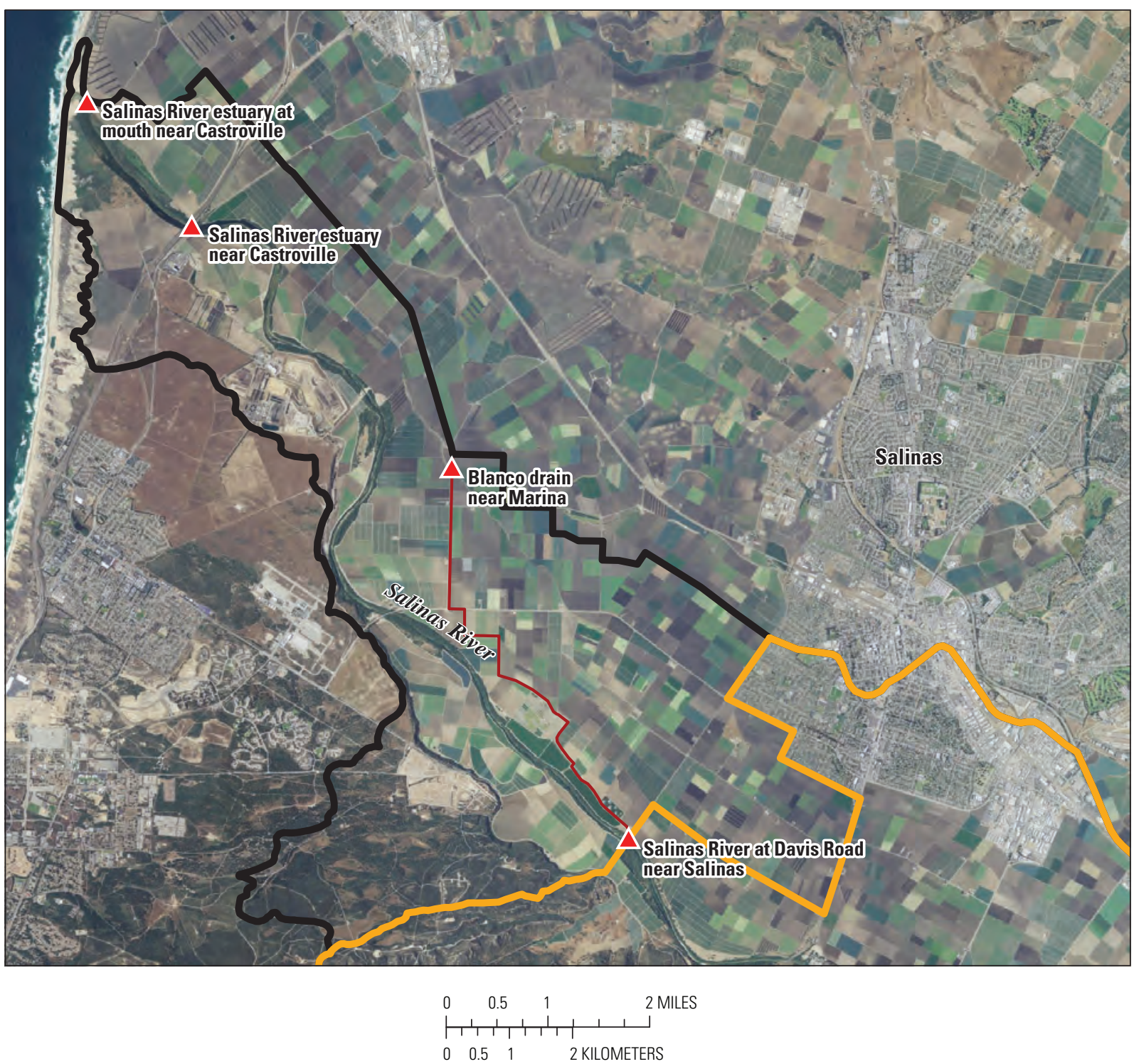

EXPLANATION

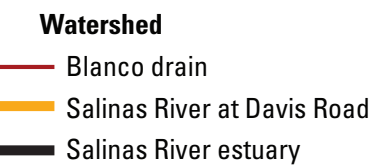

A Sampling site

Figure 3. Aerial view of land cover and location of sampling sites within the Salinas River estuary watershed. 


\section{Santa Maria River Estuary Watershed}

The Santa Maria River estuary watershed is south of the outlets of the Salinas and Pajaro watersheds, approximately 140 mi south of Monterey Bay, and drains approximately $1,830 \mathrm{mi}^{2}$ of land (fig. 1). The watershed includes the Cuyama and Sisquoc Rivers, which join to form the Santa Maria River. Discharges into the Santa Maria River estuary are dominated by Green Canyon Creek (referred to hereafter as Lower Orcutt Creek) and a drainage ditch that enters the river just upstream (fig. 4). The stretch of the Santa Maria River between the
Highway 1 crossing and the confluence upstream with the Sisquoc River is dry for most of the year. Downstream of Highway 1, the river has some year-round flow comprising primarily agricultural discharge. Both the lower Santa Maria River and Orcutt Creek are currently listed as impaired by pesticides under Clean Water Act 303(d) (State Water Resources Control Board, 2002).

The Santa Maria River estuary is landward of the Guadalupe Dunes, which block the river from entering the sea. Water collects behind the dunes and forms a large semicircular lagoon which fills until the water level reaches an elevation at

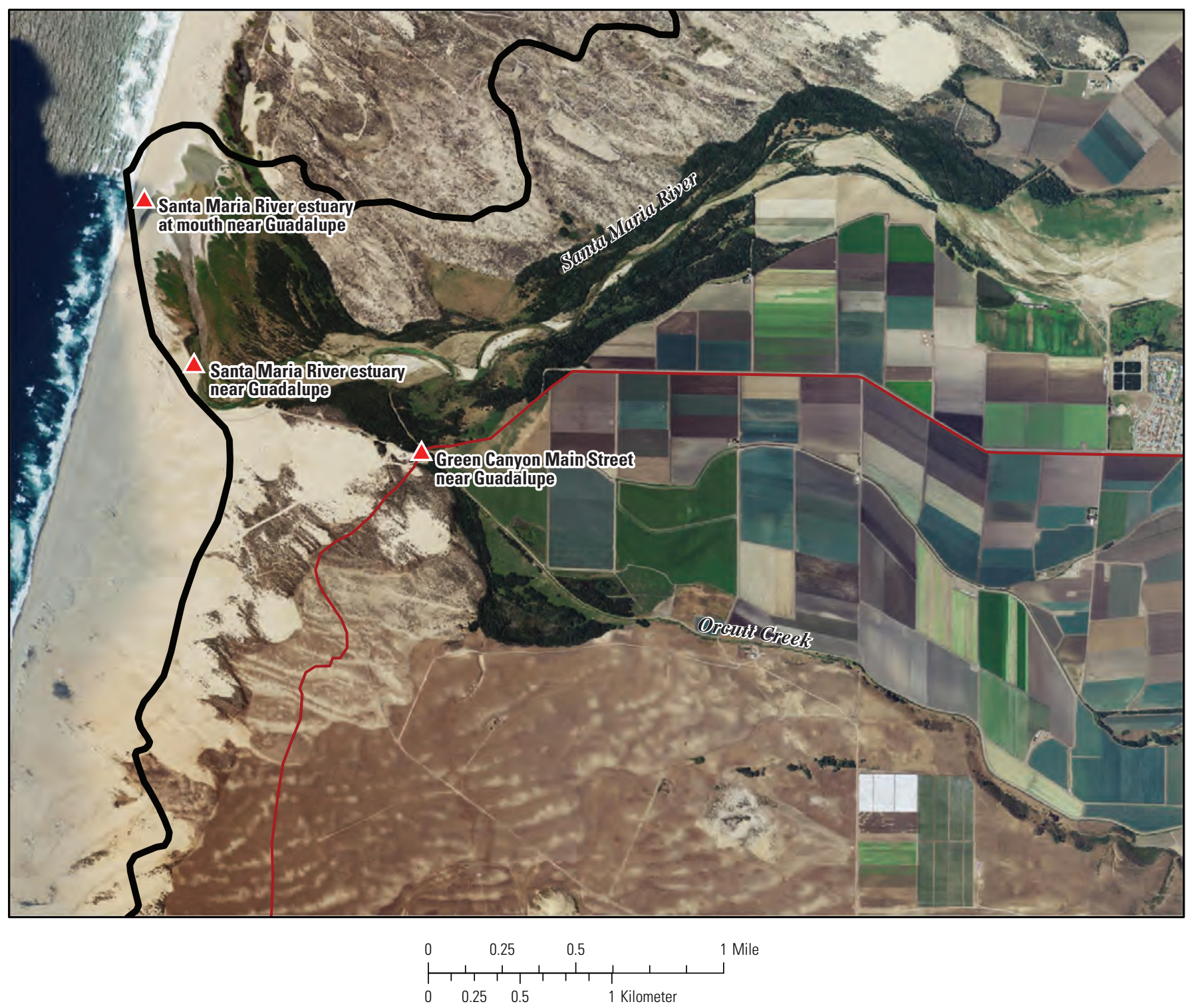

EXPLANATION

\section{Watershed}

- Lower Orcutt Creek

Santa Maria River estuary
A Sampling site

Figure 4. Aerial view of land cover and location of sampling sites within the Santa Maria River estuary watershed. 
which it can overtop the beach dune barrier. Flow then erodes the beach dune barrier and the estuary drains over a period of hours to a few days. This filling and draining cycle occurred repeatedly during the course of the study. The lower estuary sampling site (Santa Maria lower) was located as close to the beach dune barrier as possible with the precise location varying slightly with changes in estuary size during the study. The upper estuary (Santa Maria River estuary upper) site was located approximately $0.5 \mathrm{mi}$ upstream but also varied slightly in location with changes in estuary size.

Orcutt Creek, is the major tributary to the estuary, providing the majority of water to the estuary for most of the year. Samples were collected from Green Canyon Creek at Main Street near Guadalupe (Lower Orcutt Creek), approximately $0.3 \mathrm{mi}$ upstream of the confluence with the Santa Maria River and $1.1 \mathrm{mi}$ upstream of the upper estuary sampling site (fig. 4). Orcutt Creek drains approximately $87.4 \mathrm{mi}^{2}$ of land southeast of the Santa Maria River estuary. The creek drains roughly 20,000 acres of agricultural land as well as the southern portion of the city of Santa Maria, making urban development account for about 11 percent of the watershed (table 2).

\section{Pesticide Use}

Since 1990, the California Department of Pesticide Regulation (CDPR) has had a reporting system in place that requires pesticide applicators provide detailed information on pesticide use. Pesticide-use data reported by agricultural applicators contains the date and time of application, location of application to the section level as referenced by the public land survey system, pesticide product applied and amount, and the crop type to which it was applied. Pesticides applied by licensed applicators in urban settings (primarily for landscape maintenance and structural pest control) are reported with less detail, giving the product and amount applied, but only the month of application and the county in which the pesticide was applied. The CDPR reporting system does not contain information on pesticide applications made by homeowners using products purchased at retail stores. The CDPR has the most comprehensive pesticide reporting system in the nation, and this dataset is extremely valuable in assessing trends in pesticide use, changes in application patterns, and potential for environmental contamination. Pesticide application data for the 2008 calendar year are shown in this report because they were the most recent data contained in the CDPR database.

Using the watershed boundaries shown in figure 1, pesticide use data for 2008 were analyzed spatially to determine the amounts of pesticides used in each basin. Amounts of pesticides used were determined only for compounds analyzed for this study, however many additional compounds are applied in each watershed. Watersheds often cross county boundaries, and drainage systems rarely follow section lines; therefore, individual pesticide applications were spatially weighted to better estimate the total pesticide use in an individual watershed. The portion of each section within a particular watershed was calculated and the percentage relative to the full section area was determined. Pesticide applications within each section were multiplied by the percentage of the area in a particular watershed to better approximate pesticide use in that watershed and to eliminate over-reporting of applications for adjacent watersheds. For example, if 50 percent of section 09N35W11S lies within the Orcutt Creek watershed, then all pesticide applications within that section were adjusted to 50 percent when reported for that watershed.

Pesticide-use data for most applications made in urban settings are reported by county only. To approximate the amount of this pesticide use by watershed, the watershed area falling within a county was determined, which was then divided by the total county area, and the resulting fraction was used as a multiplier for pesticide use in the county. This process was repeated for watersheds that span multiple counties.

Pesticides are applied to a wide variety of crops in the watersheds studied; however, the bulk of applications are made to only a few major crops. The top five crops receiving pesticides and the amounts of pesticides applied, in pounds, for each of the watersheds is listed in table 3. The two larger Salinas River watersheds (Salinas River at Davis Road and Salinas River estuary upper/Salinas River estuary lower) had substantially higher total amounts of pesticides applied than any of the other basins (table 4). A breakdown of agricultural pesticide applications per acre of agriculture in each basin shows they were highest in the four smallest watersheds: Watsonville Slough, 4.8 lbs/acre; Monterey drainage ditch, 3.6 lbs/acre; Lower Orcutt Creek, 3.6 lbs/acre; and Blanco drain, 3.3 lbs/acre (table 4). 


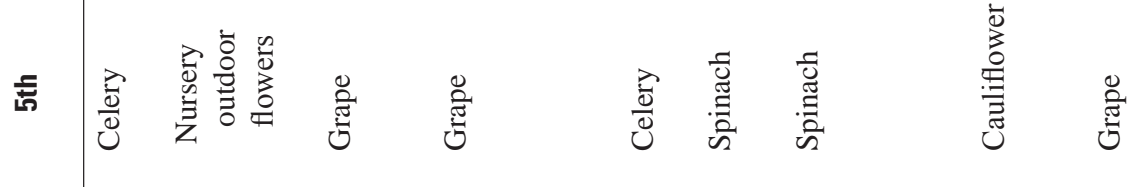

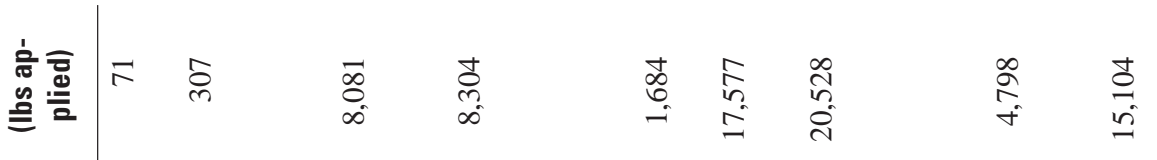

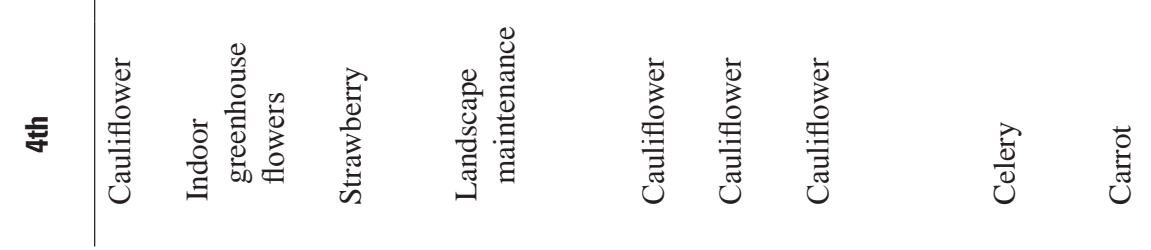

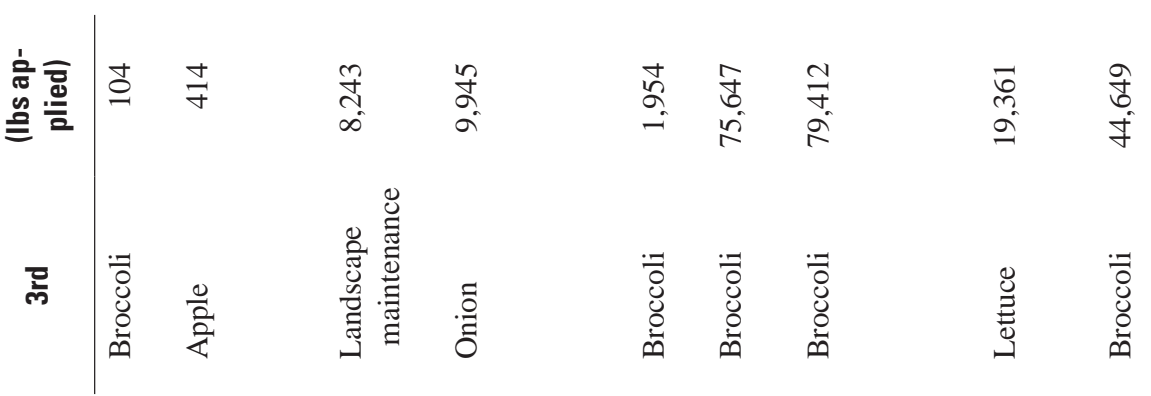

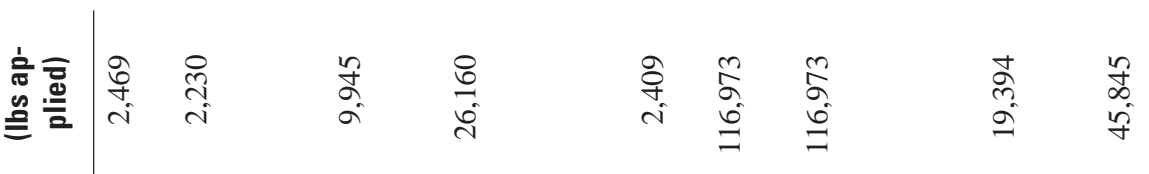

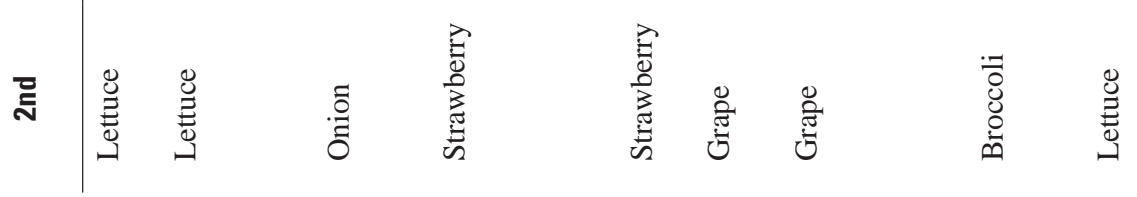

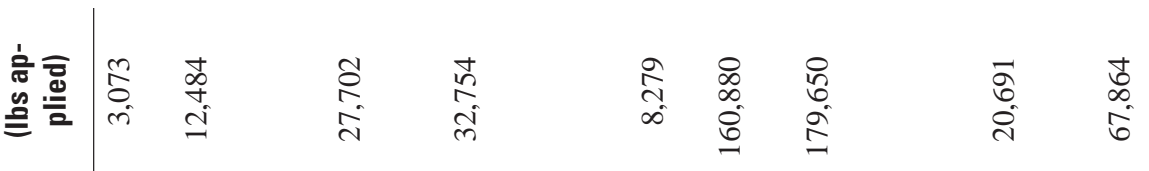

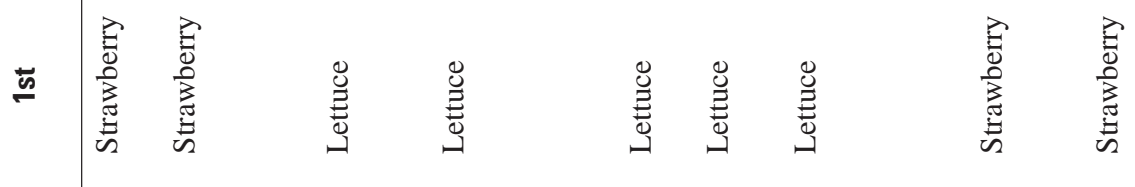

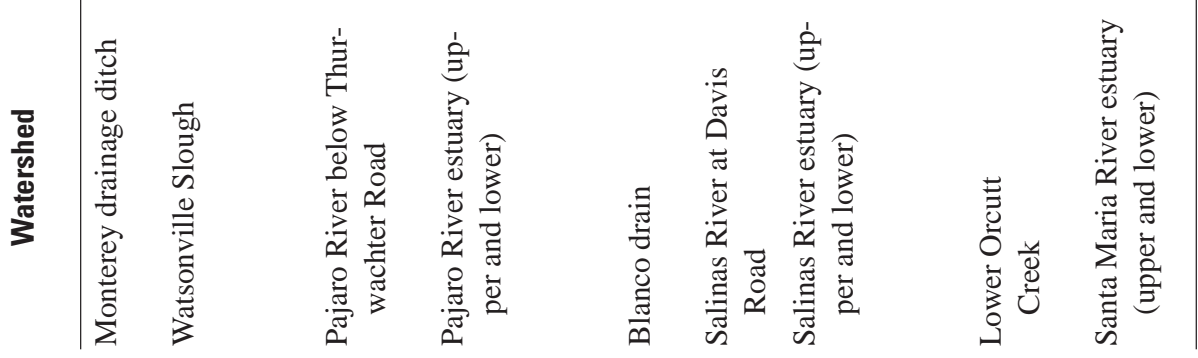


Table 4. Applications of pesticides analyzed during the study reported by land-use setting.

[Data from the pesticide use database for the 2008 calendar year (California Department of Pesticide Regulation, 2009). Abbreviations: lbs, pounds]

\begin{tabular}{|c|c|c|c|c|c|c|}
\hline Watershed & $\begin{array}{l}\text { Registered } \\
\text { agricultural } \\
\text { pesticide ap- } \\
\text { plication } \\
\text { (Ibs) }\end{array}$ & $\begin{array}{l}\text { Registered } \\
\text { urban pesticide } \\
\text { application } \\
\text { (Ibs) }\end{array}$ & $\begin{array}{l}\text { Total pesticides } \\
\text { applied in } 2008 \\
\text { (Ibs) }\end{array}$ & $\begin{array}{c}\text { Percentage of } \\
\text { pesticides from } \\
\text { urban applica- } \\
\text { tions }\end{array}$ & $\begin{array}{l}\text { Agricultural } \\
\text { land use } \\
\text { (acres) }\end{array}$ & $\begin{array}{c}\text { Pounds } \\
\text { applied per } \\
\text { agricultural } \\
\text { acre }\end{array}$ \\
\hline Monterey drainage ditch & 5,953 & 12 & 5,965 & 0.20 & 1,634 & 3.6 \\
\hline Watsonville Slough & 16,470 & 142 & 16,612 & 0.85 & 3,399 & 4.8 \\
\hline $\begin{array}{r}\text { Pajaro River estuary } \\
\text { (upper and lower) }\end{array}$ & 128,252 & 14,590 & 142,842 & 10.21 & 76,393 & 1.7 \\
\hline Blanco drain & 15,027 & 22 & 15,049 & 0.15 & 4,568 & 3.3 \\
\hline Lower Orcutt Creek & 72,441 & 426 & 72,867 & 0.58 & 19,884 & 3.6 \\
\hline $\begin{array}{l}\text { Santa Maria River estuary } \\
\text { (upper and lower) }\end{array}$ & 238,499 & 9,101 & 247,600 & 3.68 & 85,941 & 2.8 \\
\hline
\end{tabular}

\section{Procedures and Methods}

\section{Sampling Methods}

Sampling for water, bed, and suspended sediment, was conducted in the three estuaries between January 2008 and October 2009. A total of 15 sampling events took place in each estuary; 4 storm events and 11 dry season events. Sample collection procedures varied by site, and between storm and dry season events, based on hydrologic conditions. During each sampling event, stream discharge was measured at each tributary site where flow was not tidally affected, following established U.S. Geological Survey protocols (Rantz and others, 1982). Additionally, basic water-quality parameters (temperature, specific conductance, $\mathrm{pH}$, dissolved oxygen concentration, and turbidity) were measured at all sites during each sampling event using a multi-probe meter (YSI model 6920V2).

\section{Storm Sampling}

Storm sampling was initiated when greater than 0.5 in. of rain fell in the respective estuary watersheds within a 24-hour period, and flows within the smaller tributaries had increased above base flow. Two storm events were sampled in 2008 and two in 2009. Three of the storms were sampled in winter, but the last storm in 2009 was sampled in fall. Water samples were collected from all sampling sites during storm events, but suspended sediment samples were only collected at the river/tributary sites. At the larger river sites (Salinas River at Davis Road, and Pajaro River below Thurwachter) storm samples were collected during the rising limb of the stream hydrograph. At the remaining river/tributary sites storm samples were generally collected on the falling limb of the stream hydrograph.

During sampling large-volume water samples were collected for isolation of sufficient quantities of suspended material for sediment-associated pesticide analyses. Samples were collected from multiple, equally spaced points and multiple depths along a stream transect, or from one point using a high-volume peristaltic pump fitted with Teflon tubing. Transect samples were collected from three sites, Pajaro River below Thurwachter, Salinas River at Davis Road, and Lower Orcutt Creek. Single point samples were collected from the smaller tributaries (Blanco drain and Monterey drainage ditch) and in areas where transect samples were not feasible (Watsonville Slough). The collected water was pumped into pre-cleaned 20-L stainless steel soda kegs that were rinsed three times with site water prior to sampling. The total volume of water collected at each site ranged from about 400 to 1,000 L, depending on suspended-sediment concentrations. The objective was to process a sufficient volume of water to obtain at least 20 grams of suspended sediment for each site. 
Following collection, each large-volume water sample was pumped through a continuous-flow centrifuge (GEA Westphalia Separator, Inc, Northvale, New Jersey) operated at 9,500 $\mathrm{G}$ at the rate of $2 \mathrm{~L} / \mathrm{min}$ to segregate the liquid and solid phases, and concentrate suspended sediments ( $>0.3$ microns) to make a slurry. The centrifuge flow rate is based on a study of particle trapping efficiency (Horowitz and others, 1989) which found $2 \mathrm{~L} / \mathrm{min}$ using the centrifuge to be within the optimum range for particle trapping efficiency. The water exiting the centrifuge represents the liquid phase, and was collected directly into 1-L pre-cleaned glass bottles to be analyzed for dissolved pesticides. The sediment slurry remaining in the centrifuge bowls was transferred to $0.5-\mathrm{L}$ precleaned glass jars and shipped on ice to the U.S. Geological Survey Organic Chemistry Laboratory in Sacramento, California (Sacramento Laboratory). In the laboratory the sediment slurry was further dewatered using a Sorvall RC-5B high-speed refrigerated centrifuge (Sorvall, Newport Pagnell, Buckinghamshire, England) operating at 16,210 G (or 10,000 revolutions per minute) and stored frozen until analysis. All water samples were extracted within 48 hours of collection and all sediment samples remained frozen for no longer than 1 year prior to extraction and analysis.

\section{Dry Season Sampling}

Eleven non-storm or dry season sampling events took place from April through November in each of the three estuary watersheds to represent the contribution of agricultural return waters to the estuaries throughout the local growing season. Water samples for dissolved and sediment-bound pesticides, as well as organic carbon, were collected at both the river/tributary and within estuary sites. Sampling techniques varied based on hydrologic conditions.

At the Pajaro River below Thurwachter site, depthintegrated samples were collected isokinetically across a transect using a U.S. DH-95 sampler, and following methods described in the USGS National Field Manual for the Collection of Water-Quality Data (U.S. Geological Survey, 2006). Water was collected in a pre-cleaned 1-L Teflon bottle at a minimum of five equally spaced points across the stream channel from a bridge at the site. Two verticals were sampled at each point along the transect with one Teflon bottle used to collect water for pesticide analysis and a second Teflon bottle, which used a slightly different cleaning procedure to eliminate potential methanol contamination, used to collect water for dissolved organic carbon (DOC) analyses. After completion of the sampling transect, the Teflon bottles were agitated for a minimum of 1 minute and the sample water was then poured into 1-L and $125 \mathrm{~mL}$ baked glass bottles for pesticide and DOC analyses, respectively.
Water samples collected at the remaining river/tributary sites (Monterey drainage ditch, Blanco drain, Lower Orcutt Creek, Watsonville Slough, and Salinas River at Davis Road) were collected by two methods, depending on flow and safety considerations. When flows were sufficient (typically when water depths exceeded $1 \mathrm{ft}$ ) samples were collected using a U.S. DH-81 and 1-L Teflon bottles at 3 to 5 equally spaced points across the channel depending on channel width (Wilde and others, 1998). When flows were low (water depths less than $1 \mathrm{ft}$ ), or where conditions were too dangerous to wade, water samples were collected by immersing sample bottles directly into the stream near the center of flow (dip sample). Dip samples collected from sites located within the three estuaries were obtained by wading out to a sufficient depth and immersing sample bottles. After collection, samples were transported on ice to the Sacramento Laboratory where they were stored at $4^{\circ} \mathrm{C}$ for up to 48 hours.

Bed sediment samples were collected three times during the study from each river/tributary site. Bed sediment was sampled in the middle (July) and at the end of the dry season in 2008 (October), and again at the end of the dry season in 2009 (October). Samples were collected from areas of active sediment deposition (backwaters or other low velocity zones on the stream channel margins) using a stainless steel scoop to sample the top 2-cm of bed material from multiple points within approximately a $1-\mathrm{m}^{2}$ area. Sediment was passed through a 4-mm mesh sieve into a pre-cleaned stainless steel bowl, homogenized, and transferred to 500-mL pre-cleaned glass jars. Samples were transported on ice to the Sacramento Laboratory where they were stored frozen until analysis.

\section{Analytical Methods}

\section{Dissolved Pesticides}

All water samples were separated or filtered using either the continuous flow centrifuge or pre-baked $\left(450^{\circ} \mathrm{C}\right.$ for 4 hours) 0.7 - $\mu \mathrm{m}$ glass fiber filters $(\mathrm{GF} / \mathrm{F}$ ) (Whatman, Florham Park, New Jersey) to remove/separate suspended material. Filtered water samples were analyzed for a suite of 68 pesticides by extracting $1 \mathrm{~L}$ of sample water onto Oasis HLB solid-phase extraction (SPE) cartridges (6 cc, 500 mg, $60 \mu \mathrm{m}$, Waters Corportation, Milford, Massachusetts). All samples were spiked with ${ }^{13} \mathrm{C}_{3}$-atrazine, and diazinon diethyl- $\mathrm{d}_{10}$ (Cambridge Isotopes, Andover, Massachusetts) as recovery surrogates. Following extraction, the SPE cartridges were dried, eluted with $12 \mathrm{~mL}$ of ethyl acetate, and reduced under nitrogen. After extraction, approximately $1 \mathrm{~g}$ of sodium sulfate $\left(\mathrm{Na}_{2} \mathrm{SO}_{4}\right)$ was added to the sample bottles to remove any residual water, and the bottles were rinsed three times with dichloromethane (DCM). The bottle rinses were reduced 
to $1 \mathrm{~mL}$ under nitrogen, and combined with the ethyl acetate fraction. The entire sample (bottle rinse plus SPE elution) was reduced to a final volume of $200 \mu \mathrm{L}$ for analysis. Deuterated polycyclic aromatic hydrocarbon (PAH) compounds were used as internal standards and included acenaphthene- $\mathrm{d}_{10}$ and pyrene- $\mathrm{d}_{10}$. All sample extracts were analyzed by gas chromatography-ion trap mass spectrometry (GC-ITMS). Additional details are given in Hladik and others (2008).

The filter paper containing the suspended sediment was dried at room temperature overnight (in the dark), cut up using solvent rinsed scissors, and placed into a flask with $75 \mathrm{~mL}$ DCM. Prior to extraction, the filter paper was spiked with the recovery surrogate (phenoxy- ${ }^{13} \mathrm{C}-\mathrm{C}_{6}$-cis-permethrin). The filter paper was extracted in a sonicator for 30 minutes and filtered $(\mathrm{GF} / \mathrm{F}, 0.7 \mu \mathrm{m})$. The extraction was repeated, and the two extracts were combined and reduced to $0.5 \mathrm{~mL}$. The co-extracted sample matrix was removed using stacked SPE cartridges, and sulfur was removed using a gel permeation chromatography system (see Sediment-Associate Pesticides in this report). Complete details of the method can be found in Hladik and Kuivila (2009).

\section{Sediment-Associated Pesticides}

Sediment samples were extracted based on methods described in Smalling and Kuivila (2008) for a suite of 56 pesticides. Prior to extraction, sediment samples were spiked with trifluralin- $\mathrm{d}_{10}$, ring- ${ }^{13} \mathrm{C}-p, p^{\prime}-\mathrm{DDE}$ and phenoxy- ${ }^{13} \mathrm{C}-$ cis-permethrin (Cambridge Isotopes, Andover, Massachusetts) as recovery surrogates. Wet sediments were homogenized with $\mathrm{Na}_{2} \mathrm{SO}_{4}$ using a solvent rinsed mortar and pestle, and extracted by pressurize liquid extraction (PLE) using a Dionex 200 (Sunnyvale, California) Accelerated Solvent Extractor (ASE). Samples were extracted three times with DCM at $100^{\circ} \mathrm{C}$ and 2,500 psi. Following extraction, sample extracts were dried over $\mathrm{Na}_{2} \mathrm{SO}_{4}$ and reduced to $0.5 \mathrm{~mL}$ using a Turbovap II (Zymark Corporation, Hopkins, Massachusetts). Sample matrix was removed using stacked pre-packed Carbon/ Alumina SPE cartridges containing 500 mg of nonporous, graphitized carbon (Restek Corporation, Bellefonte, Virginia) and 500-mg alumina (Varian Inc, Palo Alto, California). The cartridges were washed in tandem with $10 \mathrm{~mL}$ of DCM prior to the addition of sample extracts. Compounds of interest were eluted off both SPE cartridges with $10 \mathrm{~mL}$ of DCM, and collected as fraction 1 (F1). The carbon SPE was removed, and the alumina SPE was eluted with $10 \mathrm{~mL}$ of ethyl acetate and DCM (50:50 v/v), and collected as fraction 2 (F2). Sulfur was removed from the F1 using a gel-permeation/highperformance liquid chromatography system (GPC/HPLC) with DCM as the carrier solvent. Both fractions were kept separate and were each reduced to $200 \mu \mathrm{L}$ and analyzed for 55 pesticides (Smalling and others, 2005).

\section{Instrumental Analysis for Pesticides}

Water and sediment extracts ( $1 \mu \mathrm{L}$ injection volume) were analyzed for pesticides on a Varian Saturn 2000 (Walnut Creek, California, USA) GC-ITMS. Analyte separation on the GC-ITMS was achieved using a 30-m x 0.25-mm i.d., $0.25-\mu \mathrm{m}$ DB-5ms fused silica column (Agilent Technologies, Folsom, California) with helium as the carrier gas. The temperature of the splitless injector was held constant at $275^{\circ} \mathrm{C}$. Because of the number of compounds and instrument limitations, samples were injected twice using two different temperature programs for the GC oven: a short (30 min) and a long (61 min) temperature gradient. The fungicides and OCPs were separated from the other compounds because of greater ease in setting selected ion storage (SIS) windows. The short temperature program was $80^{\circ} \mathrm{C}$ (hold $1 \mathrm{~min}$ ) with an increase to $300^{\circ} \mathrm{C}$ at $10^{\circ} \mathrm{C} / \mathrm{min}$ (hold $10 \mathrm{~min}$ ). The long temperature program was $80^{\circ} \mathrm{C}$ (hold $0.5 \mathrm{~min}$ ), increase to $120^{\circ} \mathrm{C}$ at $10^{\circ} \mathrm{C} /$ min, increase to $200^{\circ} \mathrm{C}$ at $3^{\circ} \mathrm{C} / \mathrm{min}$ (hold $5 \mathrm{~min}$ ), followed by a third increase to $219^{\circ} \mathrm{C}$ at $3^{\circ} \mathrm{C} / \mathrm{min}$, and a final increase to $300^{\circ} \mathrm{C}$ at $10^{\circ} \mathrm{C} / \mathrm{min}$ (hold $10 \mathrm{~min}$ ). The transfer line and ion trap temperatures were $280^{\circ} \mathrm{C}$ and $220^{\circ} \mathrm{C}$, respectively. The MS was operated in electron ionization (EI) mode with an emission current of $15 \mu \mathrm{A}$ and no offset when run in full scan mode, and an emission current of $45 \mu \mathrm{A}$ with a multiplier offset of 300 volts when using SIS windows. Data were collected in full scan and SIS modes. Complete details of the analytical method are described in Crepeau and others (2000), LeBlanc and others (2004), and Smalling and Kuivila (2008).

Calibration of the GC-ITMS was achieved using calibration standards that spanned the linear range of instrument response. An eight-point calibration standard was developed with concentrations ranging from 0.025 to $5.0 \mathrm{ng} / \mu \mathrm{L}$. Calibration curves were considered acceptable if the $\mathrm{R}^{2}$ for each individual compound was greater than 0.995 . The responses of the instrument was monitored every 6-8 samples with mid-level check standards. The instruments were considered to be stable if the recovery of the check standards were within the range of 80-115 percent of the nominal standard concentration. If environmental sample concentrations fell outside the linear range of the instrument, the samples were diluted appropriately and reanalyzed. 


\section{Method Detection Limits}

Surface-water and sediment method detection limits (MDLs) were validated in previous studies (Hladik and others, 2008; Smalling and Kuivila, 2008) by using the EPA procedure described in 40 CFR Part 136 (U.S. Environmental Protection Agency, 1992). Water samples used to determine MDLs were collected in 2005 from the Sacramento River at Miller Park, and suspended sediment samples were collected in 2004 from the Cache Creek inflow to the settling basin near Woodland (USGS site identification number 384340121434401). The MDLs were calculated for each compound using the following equation:

$$
M D L=S \times t(n-1,1-\alpha=0.99)
$$

where

$$
\begin{aligned}
M D L= & \text { method detection limit }(\mu \mathrm{g} / \mathrm{kg}), \\
S= & \text { standard deviation of replicate samples, } \\
n= & \text { number of replicates, and } \\
t= & \text { value of Student 's } t \text { statistic with } \\
& \quad 6 \text { degrees of freedom at a } 99 \text { percent } \\
& \text { confidence level. }
\end{aligned}
$$

\begin{tabular}{|c|c|c|c|c|c|}
\hline Compound & $\begin{array}{l}\text { Method de- } \\
\text { tection limit }\end{array}$ & Compound & $\begin{array}{l}\text { Method } \\
\text { detection } \\
\text { limit }\end{array}$ & Compound & $\begin{array}{l}\text { Method de- } \\
\text { tection limit }\end{array}$ \\
\hline \multicolumn{2}{|c|}{ Anilines } & \multicolumn{2}{|l|}{ Organochlorines } & \multicolumn{2}{|c|}{ Thiocarbamates } \\
\hline 3,4-DCA & 8.3 & Pentachloroanisole (PCA) & 4.7 & Butylate & 1.8 \\
\hline $3,5-$ DCA $^{1}$ & 8.0 & Pentachloronitrobenzene (PCNB) & 3.1 & Cycloate & 1.1 \\
\hline Ethalfluralin & 3.0 & $p, p^{\prime}-\mathrm{DDE}$ & 4.1 & EPTC & 1.5 \\
\hline Pendimethalin & 2.3 & $p, p^{\prime}-\mathrm{DDD}$ & 3.6 & Molinate & 3.2 \\
\hline Propanil & 10.1 & $p, p^{\prime}-\mathrm{DDT}$ & 4.0 & Pebulate & 2.3 \\
\hline Trifluralin & 2.1 & Organophosphates & & Thiobencarb & 1.9 \\
\hline \multicolumn{2}{|c|}{ Azoles/triazoles } & Chlorpyrifos & 2.1 & \multicolumn{2}{|c|}{ Triazines/triazones } \\
\hline Cyproconazole & 11.2 & Diazinon $^{2}$ & 0.9 & Atrazine & 2.3 \\
\hline Fipronil & 2.9 & Malathion & 3.7 & Hexazinone & 8.4 \\
\hline Fipronil desulfinyl & 1.6 & Methidathion & 7.2 & Prometryn & 1.8 \\
\hline Fipronil sulfide & 1.8 & Methylparathion & 3.4 & Propyzamide $^{1}$ & 5.0 \\
\hline Fipronil sulfone & 3.5 & Phosmet & 4.4 & Simazine & 5.0 \\
\hline Metconazole & 11.5 & \multicolumn{2}{|l|}{ Pyrethroids } & \multicolumn{2}{|c|}{ Strobilurins } \\
\hline Myclobutanil & 9.2 & Allethrin & 10.0 & Azoxystrobin & 9.3 \\
\hline Propiconazole & 8.8 & Bifenthrin & 4.7 & Trifloxystrobin & 3.9 \\
\hline Tebuconazole & 10.2 & Cyfluthrin & 5.2 & Pyraclostrobin ${ }^{1}$ & 10.0 \\
\hline Tetraconazole & 8.2 & Cyhalothrin & 2.0 & \multicolumn{2}{|c|}{ Miscellaneous } \\
\hline Triflumizole $^{1}$ & 10.0 & Cypermethrin & 5.6 & Chlorothalonil & 12.1 \\
\hline \multicolumn{2}{|c|}{ Carbamates } & Deltamethrin & 3.5 & Boscalid $^{1}$ & 5.0 \\
\hline Carbaryl & 6.5 & Esfenvalerate & 3.9 & DCPA & 2.0 \\
\hline Carbofuran $^{2}$ & 3.1 & Fenpropathrin & 4.1 & Iprodione & 8.7 \\
\hline \multicolumn{2}{|c|}{ Chloroacetanilides } & $\tau$-Fluvalinate & 5.3 & Methoprene & 8.4 \\
\hline Alachlor & 1.7 & Permethrin & 3.4 & Napropamide & 11.3 \\
\hline \multirow[t]{3}{*}{ Metolachlor } & 1.5 & Phenothrin & 5.1 & Oxyfluorfen & 3.1 \\
\hline & & Remethrin & 5.7 & Piperonyl butoxide & 2.3 \\
\hline & & Tetramethrin & 2.9 & Vinclozolin $^{1}$ & 5.0 \\
\hline
\end{tabular}

MDLs for dissolved pesticides in surface water ranged from 0.9 to $12.1 \mathrm{ng} / \mathrm{L}$ (table 5) and from 0.6 to $3.6 \mu \mathrm{g} / \mathrm{kg}$ in sediments (table 6). For several compounds MDLs were not available, so calculated limits of detection (LOD) were used

Table 5. Method detection limits for dissolved pesticides in water.

[Concentrations in nanograms per liter]

\footnotetext{
${ }^{1}$ Limit of detection (LOD) was used because method detection limit was not available.

${ }^{2}$ The compound was detected in unspiked water.
} 
Table 6. Method detection limits for pesticides associated with bed and suspended sediments.

[Concentrations in micrograms per kilogram]

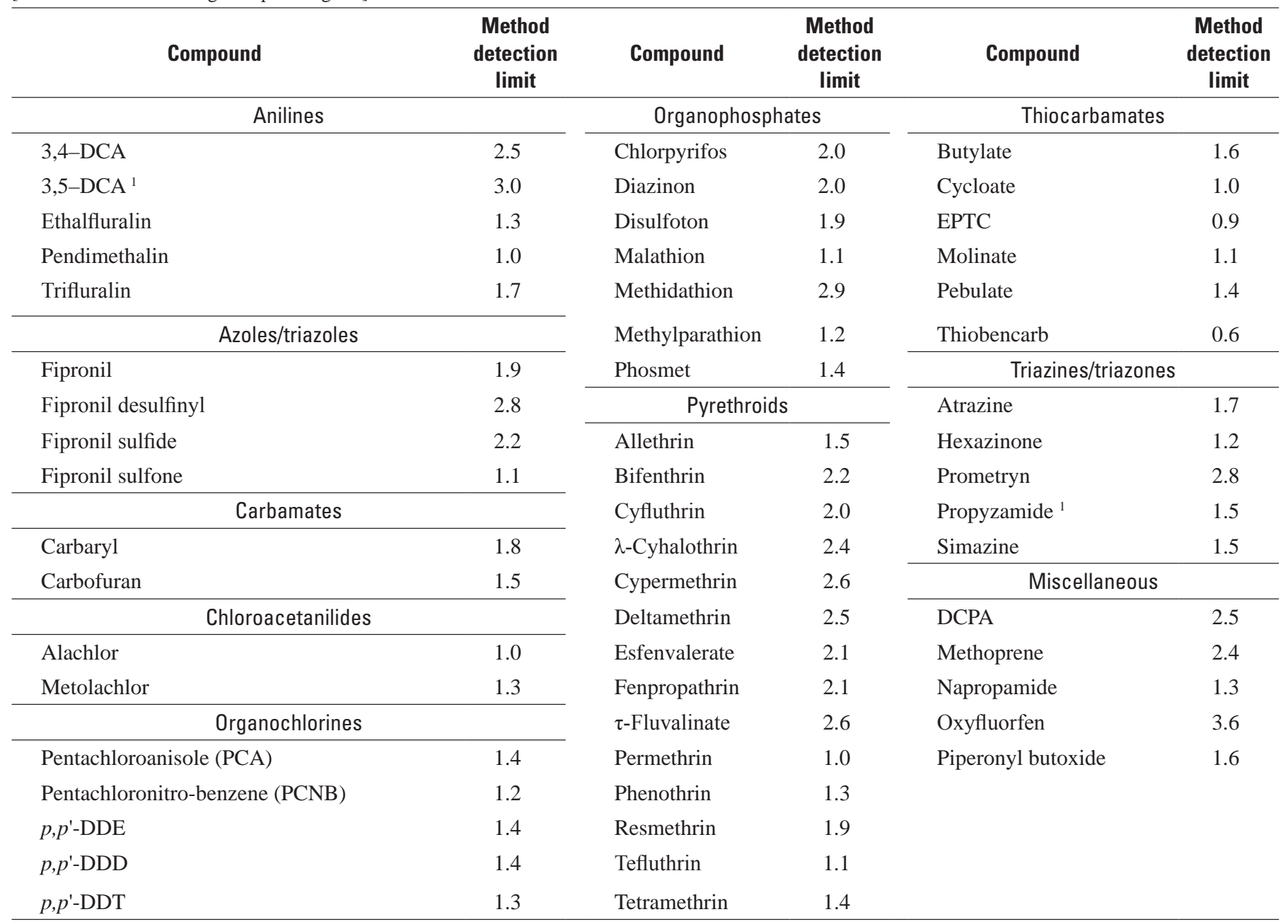

${ }^{1}$ Limit of detection (LOD) was used because method detection limit was not available.

instead. LODs were calculated as the amount of analyte in the spiked sample that produced a signal to noise ratio greater that three times the background signal. Analytes can be identified at concentrations less than the MDL or LOD with a lower confidence in the actual value; therefore, concentrations of compounds detected below the MDLs are reported as estimates and are presented in parentheses in the data tables.

\section{Quality Assurance/Quality Control}

Pesticide concentrations in water and sediments were validated against a comprehensive set of performance-based quality assurance/quality control (QA/QC) criteria including field and laboratory blanks, replicates, laboratory matrix spikes, laboratory matrix spike replicated, certified reference material, and surrogate recovery compounds. All QC results met or exceeded guidelines established by the Surface Water Ambient Monitoring Program (SWAMP; State Water Resources Control Board, 2002). All environmental and QC data were reviewed by project staff and by the U.S. Geological Survey California Water Science Center Water-Quality Specialist. Results for the target constituents in environmental samples were of acceptable quality. 


\section{Dissolved Pesticides}

Four field and four laboratory blanks were analyzed as part of established SWAMP criteria. No pesticides were detected in any of the field or laboratory blanks during the course of the study. Ring- ${ }^{13} \mathrm{C}_{3}$-atrazine and diazinon diethyl- $\mathrm{d}_{10}$ were used as recovery surrogates to assess the efficiency of sample extraction. Mean recoveries, with standard deviation, of ring- ${ }^{13} \mathrm{C}_{3}$-atrazine and diethyl- $\mathrm{d}_{10}$ diazinon for all samples analyzed, including QC samples, were $89 \pm 12$ percent and $95 \pm 10$ percent, respectively. Sample data were excluded if recovery was less than 75 percent; since all samples had recoveries greater than 75 percent, all data points were reported. Eight replicate field samples were analyzed and the relative percent differences ranged from 1 to 20 for all pesticides detected. Relative percent differences for all pesticides detected in replicate sample pairs ranged from 0.4 to 23.5. Twelve matrix spikes were analyzed in approximately 10 percent of all samples as part of the method validation. The recoveries of pesticides in the matrix-spiked samples ranged from 75-120 percent. Matrix-spike replicates were analyzed every 20 samples as part of the established SWAMP guidelines, and the relative percent differences ranged from 0.3 to 22, depending on the compound. Mean recoveries of the 35 compounds in USGS National Water Quality Laboratory’s Schedule 2033 field spike mixture (National Water Quality Laboratory, Denver, Colorado) that were added to sample water as a certified reference material were $94 \pm 13.8$ percent with recoveries ranging from 70 to 125 percent.

\section{Sediment-Associated Pesticides}

Three laboratory blanks consisting of approximately $5 \mathrm{~g}$ baked sodium sulfate $\left(\mathrm{Na}_{2} \mathrm{SO}_{4}\right)$ as a sediment substitute were analyzed with every batch of 18 samples. No pesticides were detected in any of the laboratory blank samples. Final method recoveries in spiked sediment ranged from 72 to 124 percent. Mean recoveries, with standard deviation, of trifluralin- $\mathrm{d}_{10}$, ring- ${ }^{13} \mathrm{C}_{12}-p, p^{\prime} \mathrm{DDE}$, and phenoxy- ${ }^{13} \mathrm{C}_{6}$-cis-permethrin, used as recovery surrogates, were $91 \pm 13$ percent, $96 \pm 12$ percent, and $91 \pm 11$ percent, respectively. Of the compounds detected in the four laboratory replicate samples, relative percent differences ranged from 0.1 to 25 . Four matrix spikes were analyzed and the recoveries ranged from 73 to 124 percent for all compounds. Three additional replicate field samples were analyzed as a matrix spike/matrix spike duplicate (MS/MSD) pairs to monitor for recovery compared to the respective unspiked field samples, and for variability between spiked samples, as part of established SWAMP guidelines. The recoveries for these MS/MSD pairs ranged from 75 to 110 percent and the relative percent differences ranged from 0.0 to 25. Standard Reference Material (SRM) 1941b, Organics in Marine Sediment (National Institute of Standard, Gaithersburg, Maryland) was chosen as an appropriate reference material since no standard reference material is available for the current-use pesticides. Mean recoveries
( \pm standard deviation) of $p, p^{\prime}-\mathrm{DDD}$ and $p, p^{\prime}-\mathrm{DDE}$ in SRM $1941 \mathrm{~b}$ were $93 \pm 5.6$ and $103 \pm 7.6$ percent, respectively. Calculated concentrations for all compounds fell within the 95 percent confidence intervals for the certified values.

\section{Sediment Organic Carbon and Nitrogen}

Bed and suspended sediments were analyzed for organic carbon and nitrogen content using a Perkin Elmer CHNS/O analyzer (Perkin Elmer Corporation, Norwalk Connecticut). Acetanilide was used for instrument calibration. Before analysis, sediments were dried at $100^{\circ} \mathrm{C}$ for 3 hours. Dry, homogenized sediments were combusted at $925^{\circ} \mathrm{C}$ in silver boats after being exposed to concentrated hydrochloric acid (HCl) fumes in a desiccator for 24 hours to remove inorganic carbon.

\section{Dissolved Organic Carbon}

Filtered water samples were analyzed for dissolved organic carbon (DOC) by high-temperature catalytic combustion using a Shimadzu TOC- $\mathrm{V}_{\mathrm{CNS}}$ total organic carbon analyzer (Shimadzu Scientific Instruments, Columbia, Maryland) according to a modified version of USEPA 415.3 (Potter and Wimsatt, 2005). The instrument was calibrated using potassium hydrogen phthalate standards prepared in organic free water with concentrations of the standard ranging from 0.0 to $4.0 \mathrm{mg} / \mathrm{L}$. All standards, blanks and environmental samples were acidified prior to analysis using approximately four drops of concentrated sulfuric acid to lower the $\mathrm{pH}$ to approximately 1.9. The accuracy and precision of the measurements were within 5 percent as indicated by internal standards (potassium nitrate and caffeine), laboratory replicates, and matrix spikes (Bird and others, 2003)

\section{Results}

\section{Dissolved Pesticides}

A total of 31 pesticides were detected in 57 water samples collected from the Pajaro River estuary watershed, with concentrations ranging from less than the method detection limits to 36,030 ng/L. The detection frequencies ranged from 2 to 91 percent. The most frequently detected pesticides were azoxystrobin, boscalid, DCPA, diazinon, myclobutanil, and $p, p^{\prime}$-DDE, each of which were detected in greater than 50 percent of the samples from the Pajaro River estuary watershed (fig. 5). The compounds with the highest maximum concentrations were boscalid, carbaryl, malathion, myclobutanil, and pyraclostrobin, each with a maximum concentration greater than 1,000 ng/L (table 7, 8 [table 8 at back of report]). 


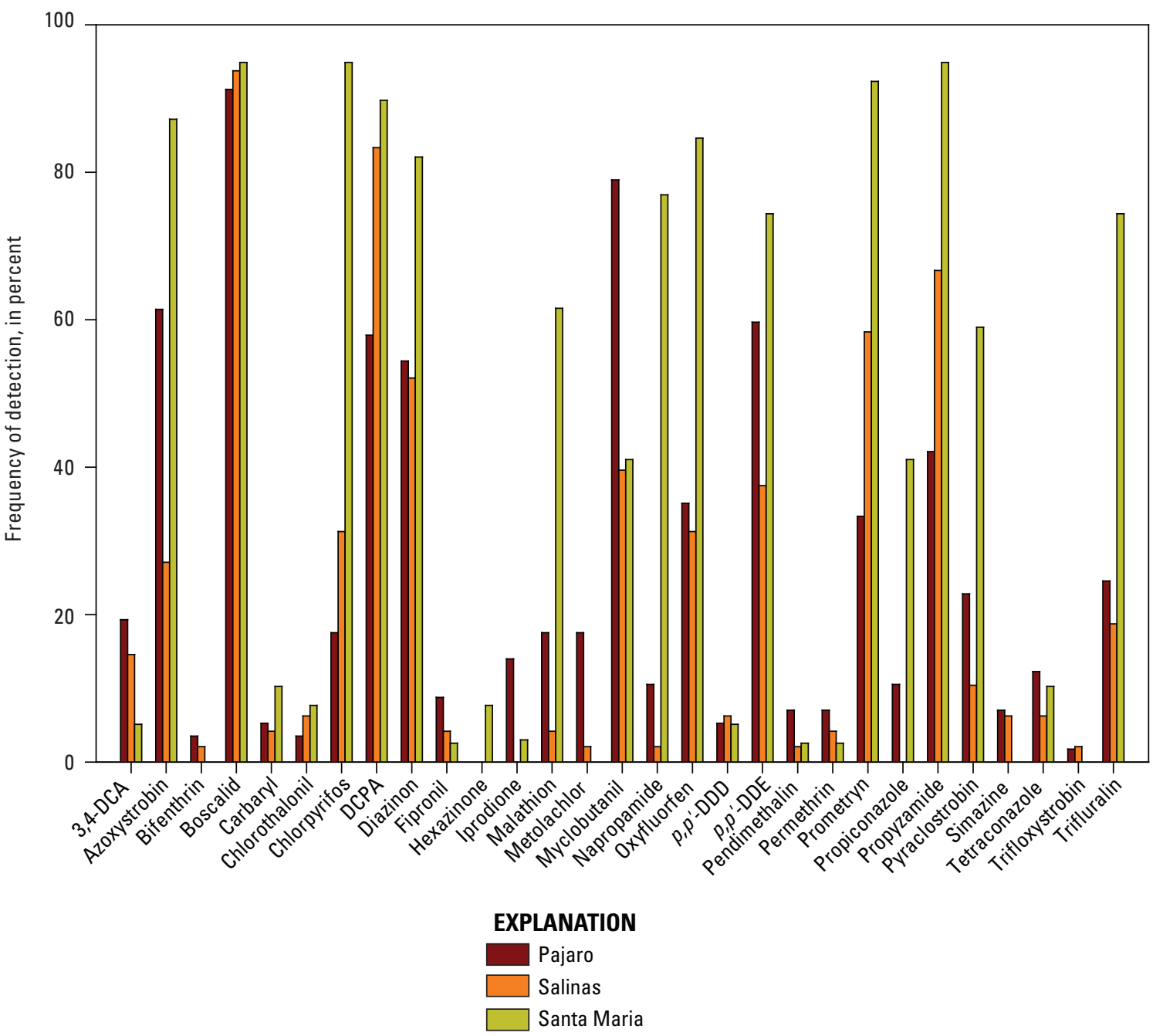

Figure 5. Detection frequencies of dissolved pesticides, as a percentage of the total number of water samples by estuary. Only compounds with a detection frequency of greater than 5 percent were included.

A total of 31 pesticides were detected in 48 water samples collected from the Salinas River estuary watershed (table 9 at back of report), with detection frequencies as high as 94 percent and concentrations up to 4,550 ng/L (azoxystrobin). The most frequently detected pesticides were boscalid, DCPA, diazinon, prometryn, and propyzamide, each of which was detected in greater than 50 percent of the samples from the Salinas River estuary watershed (fig. 5). The compounds with the highest maximum concentrations were azoxystrobin, malathion, and myclobutanil, each with a maximum concentration greater than 1,000 ng/L (tables 7, 9).

A total of 29 pesticides were detected in 39 water samples collected from the Santa Maria River estuary watershed (table 10 at back of report), with detection frequencies as high as 95 percent (boscalid, chlorpyrifos and propyzamide) and concentrations up to $14,041 \mathrm{ng} / \mathrm{L}$ (propyzamide). The most frequently detected pesticides were azoxystrobin, boscalid, chlorpyrifos, DCPA, diazinon, malathion, napropamide, oxyfluorfen, $p, p^{\prime}$-DDE, prometryn, propyzamide,

pyraclostrobin, and trifluralin, each of which were detected in greater than 50 percent of the samples (fig. 5). The compounds with the highest maximum concentrations were boscalid, chlorpyrifos, malathion, propyzamide, and pyraclostrobin, each with a maximum concentration greater than $1,000 \mathrm{ng} / \mathrm{L}$ (tables 7, 10). 
Table 7. Maximum concentrations of dissolved pesticides by estuary and season (storm versus dry) in the Pajaro, Salinas, and Santa Maria River estuary watersheds, California, 2008-09.

[Concentrations are in nanograms per liter. Results in parenthesis ( ) are below method detection limits and are estimates. Abbreviations: ND, not detected]

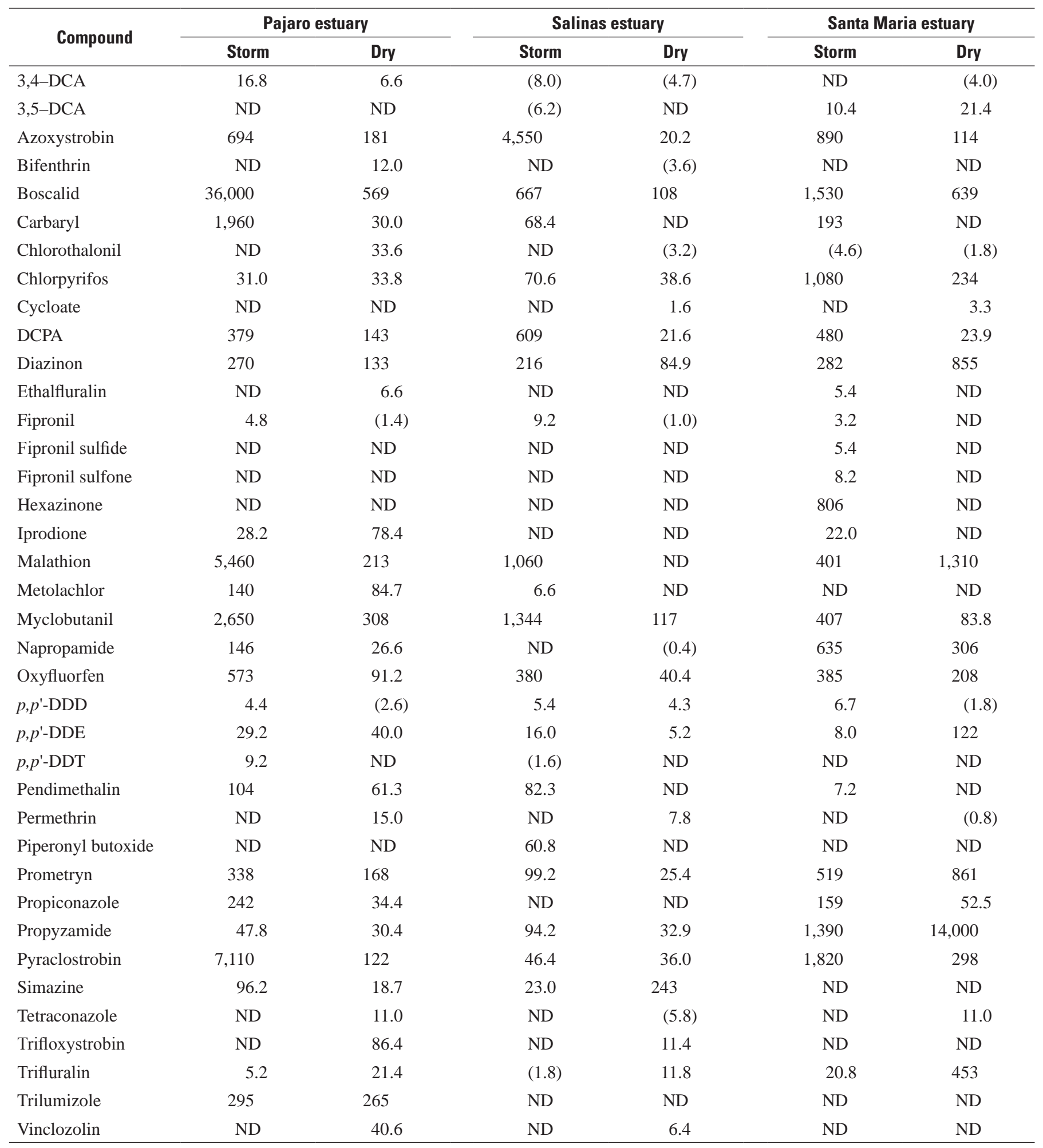


Thirty-eight pesticides were detected in the three Central Coast estuaries over the course of the study. The types of pesticides detected in each estuary watershed were similar; however, the frequency of detection and maximum pesticide concentrations differed between the three watersheds. For the majority of the pesticides, detection frequencies were higher in the Santa Maria River estuary compared to the other two estuaries (fig. 5). Boscalid, a carboxamide fungicide, was detected most frequently in all three estuaries ( fig. 5) throughout the year. Myclobutanil, a triazole fungicide, was the only pesticide detected much more frequently in the Pajaro (78 percent) than in the Santa Maria and Salinas estuaries (40 and 42 percent, respectively; fig. 5). Eleven pesticides were at their maximum concentration in samples collected from the Pajaro and the Santa Maria estuaries, while only four were detected at the highest concentration in samples collected from the Salinas (table 7).

Twenty-five pesticides were detected in samples collected from all 3 estuaries during storm events in 2008 and 2009, and 26 pesticides were detected in samples collected during the summer dry season (fig. 6). On average, detection frequencies and concentrations were higher for most compounds during the winter storm events as compared to the summer dry season (fig. 6). Fifteen of the 25 pesticides detected during the winter and fall storm sampling events were observed at their highest concentrations. Only four of the most frequently detected compounds were observed at their highest concentrations during the dry season: diazinon, $p, p^{\prime}$-DDE, prometryn, and propyzamide, particularly in the Santa Maria River estuary (table 7).

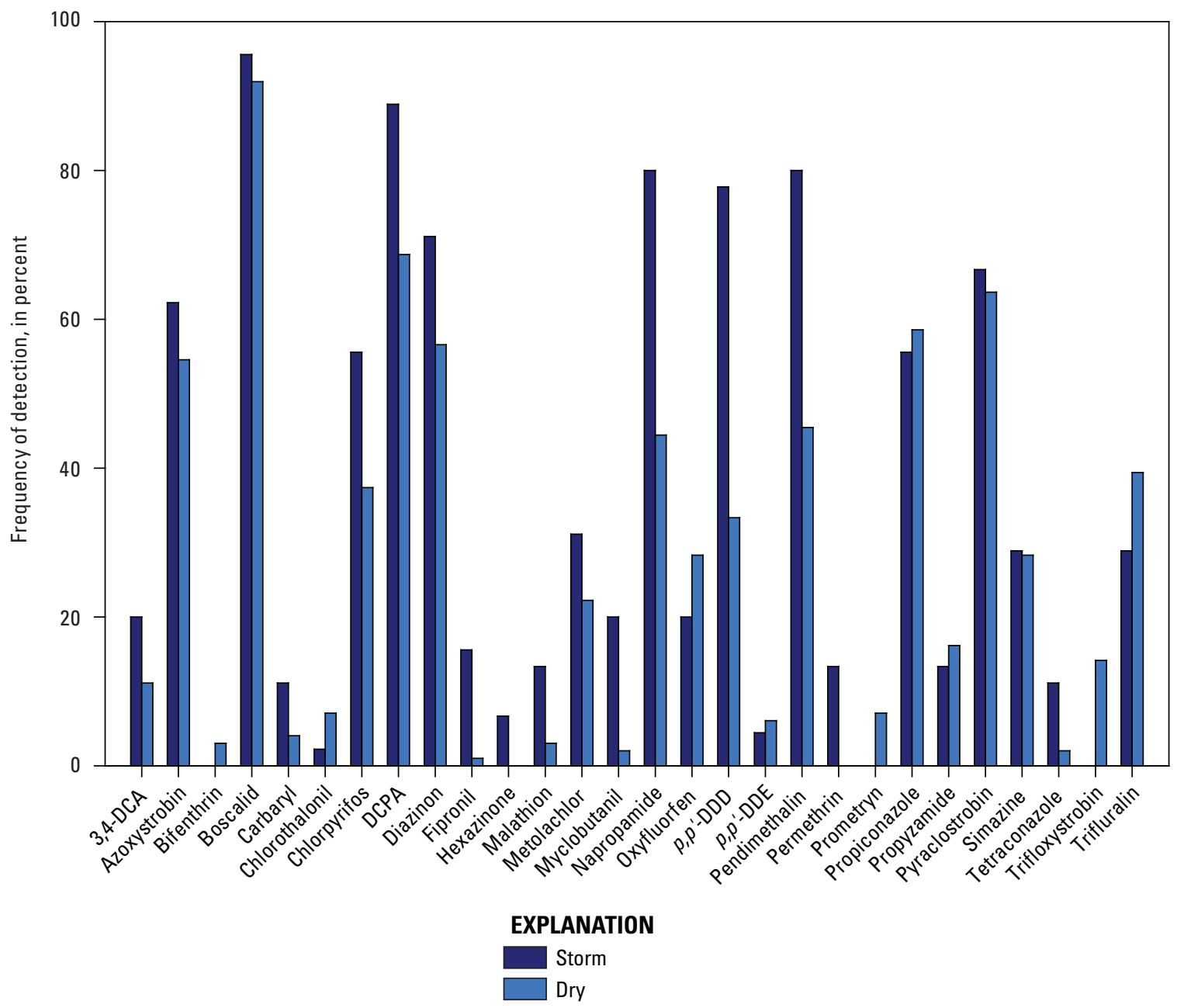

Figure 6. Detection frequencies of dissolved pesticides, as a percentage of the total number of samples by sampling period (storm versus dry) in the Pajaro, Salinas and Santa Maria River estuary watersheds, California, 2008-09. 


\section{Sediment-Bound Pesticides}

In 18 bed-sediment samples collected from the major tributaries within the 3 watersheds, 17 pesticides were detected (table 11 at back of report). Maximum concentrations ranged from 1 to $234 \mu \mathrm{g} / \mathrm{kg}$ sediment dry weight ( $p, p^{\prime}$-DDE). $p, p^{\prime}$-DDE, the persistent breakdown product of the legacy insecticide $p, p^{\prime}$-DDT, was detected in 89 percent of the bed sediment samples from all three estuaries combined and at higher concentrations than the other pesticides ( fig. 7, table 11). A total of ten pesticides were detected at least once in the three major tributaries of the Pajaro River estuary (Monterey drainage ditch, Pajaro River at Thurwatcher, and Watsonville Slough) with maximum concentrations ranging from less than 1 to $234 \mu \mathrm{g} / \mathrm{kg}$ dry weight. $p, p^{\prime}$-DDD and $p, p^{\prime}$-DDE were the only two compounds detected in more than 50 percent of the samples from the Pajaro River estuary watershed (fig. 7). Eight pesticides were detected at least once in the Salinas River estuary watershed (Blanco drain and the Salinas River at Davis Road); with maximum concentrations ranging from 2.1 to $216 \mu \mathrm{g} / \mathrm{kg}$ dry weight (table 11 ). Five compounds were detected in more than 50 percent of the bed sediment samples from the Salinas River estuary watershed, including chlorpyrifos, DCPA, $p, p^{\prime}$-DDD, $p, p^{\prime}$-DDE, and $p, p^{\prime}$-DDT ( fig. 7). Of the 17 pesticides detected in bed sediment samples, 15 were detected in the major tributary of the Santa Maria River estuary watershed (Lower Orcutt Creek) and 8 were detected in every sample (fig. 7). Maximum concentrations of pesticides detected in Lower Orcutt Creek ranged from $<1$ to $80.8 \mu \mathrm{g} / \mathrm{kg}$ dry weight, and were lower than the other two watersheds (table 11).

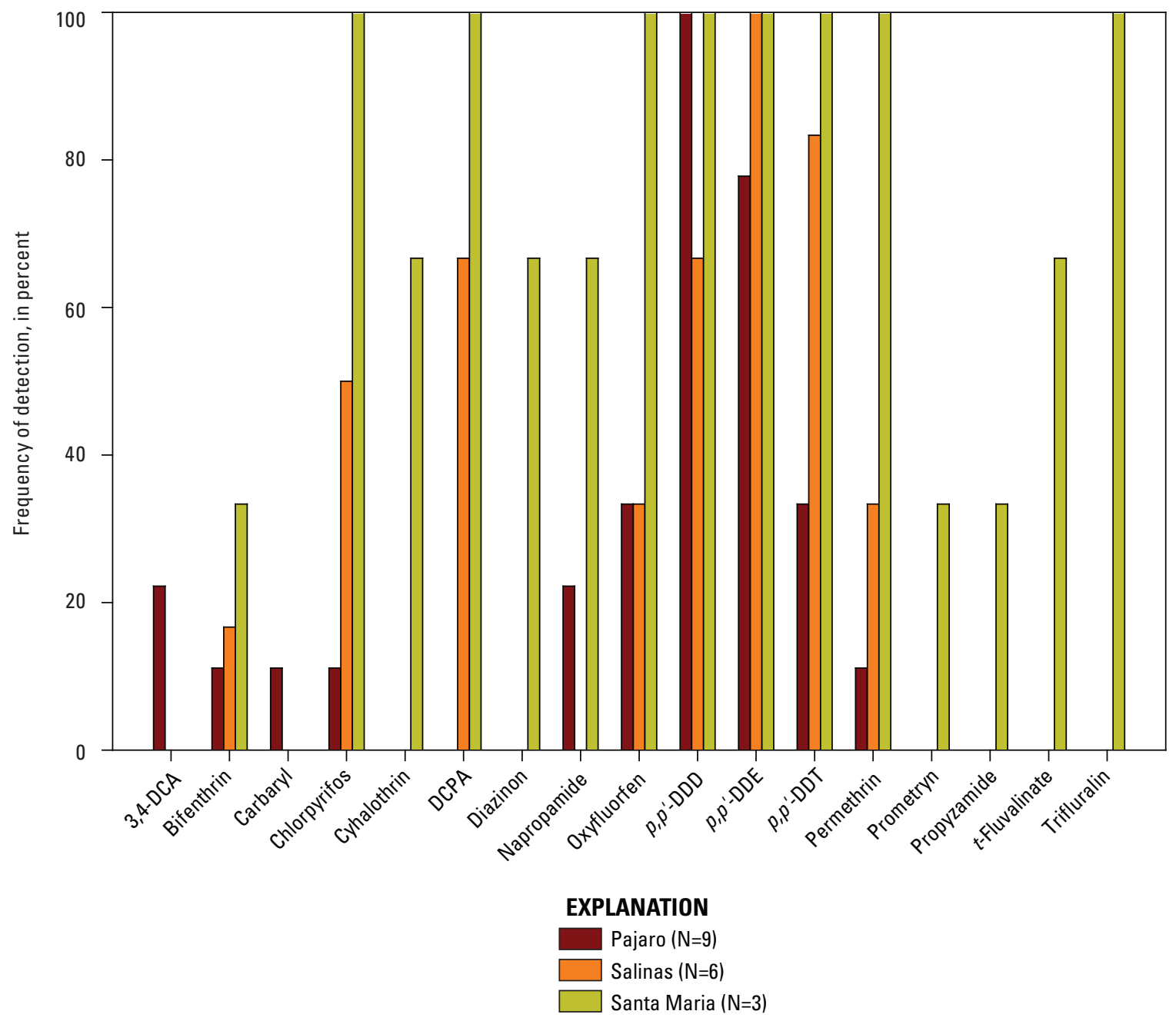

Figure 7. Frequency of detection for pesticides in bed sediments, as a percentage of the total number of samples by estuary watershed, Pajaro, Salinas, and Santa Maria River estuary watersheds, California, 2008-09. 
Nineteen pesticides were detected in suspended sediments collected from the three watersheds during four storm events in 2008 and 2009 and during three to four dry season events in 2009 (table 12 at back of report). Maximum pesticide concentrations in the three watersheds ranged from $<1$ to $549 \mu \mathrm{g} / \mathrm{kg}$ dry weight. For the Pajaro estuary watershed, 16 pesticides were detected with maximum concentrations ranging from 0.2 to $400 \mu \mathrm{g} / \mathrm{kg}$ dry weight (table 12); no pesticide was detected more than 50 percent of the time, though $p, p^{\prime}$-DDE and $p, p^{\prime}$ - DDT were detected most frequently (42 percent) and at the highest concentrations (fig. 8). For the Salinas River estuary watershed, 15 pesticides were detected in suspended sediment samples, with maximum concentrations ranging from 0.2 to $349 \mu \mathrm{g} / \mathrm{kg}$ dry weight (table 12); no pesticide was detected in more than 50 percent of the samples, though $p, p^{\prime}$-DDE was the most frequently detected (35 percent) while bifenthrin, a pyrethroid insecticide, was detected at the highest concentration (fig. 8, table 12). For the Santa Maria River estuary watershed, 15 pesticides were detected in suspended sediment samples, with maximum concentrations ranging from 0.8 to $549 \mu \mathrm{g} / \mathrm{kg}$ dry weight (table 12). In this watershed, four pesticides (chlorpyrifos, $p, p^{\prime}$-DDE, $p, p^{\prime}$-DDT, and trifluralin) were detected in more than 50 percent of the samples and at some of the highest concentrations found in the study (fig. 8, table 12).

Of the 19 pesticides detected in suspended sediment samples from the tributaries, all were detected in samples collected during the storm events, while only 10 were detected in samples collected during the dry season (fig. 9). While no pesticides were detected in more than 50 percent of the samples collected during the dry season, eight pesticides were detected in more than 50 percent of the storm samples. $p, p^{\prime}$-DDE was the most frequently detected pesticide in suspended sediment samples collected during the storm and dry seasons (92 and 24 percent, respectively). Although, chlorpyrifos was not the most frequently detected pesticide, it was detected at the highest pesticide concentrations found in this study during the storm events as well as during the dry season.

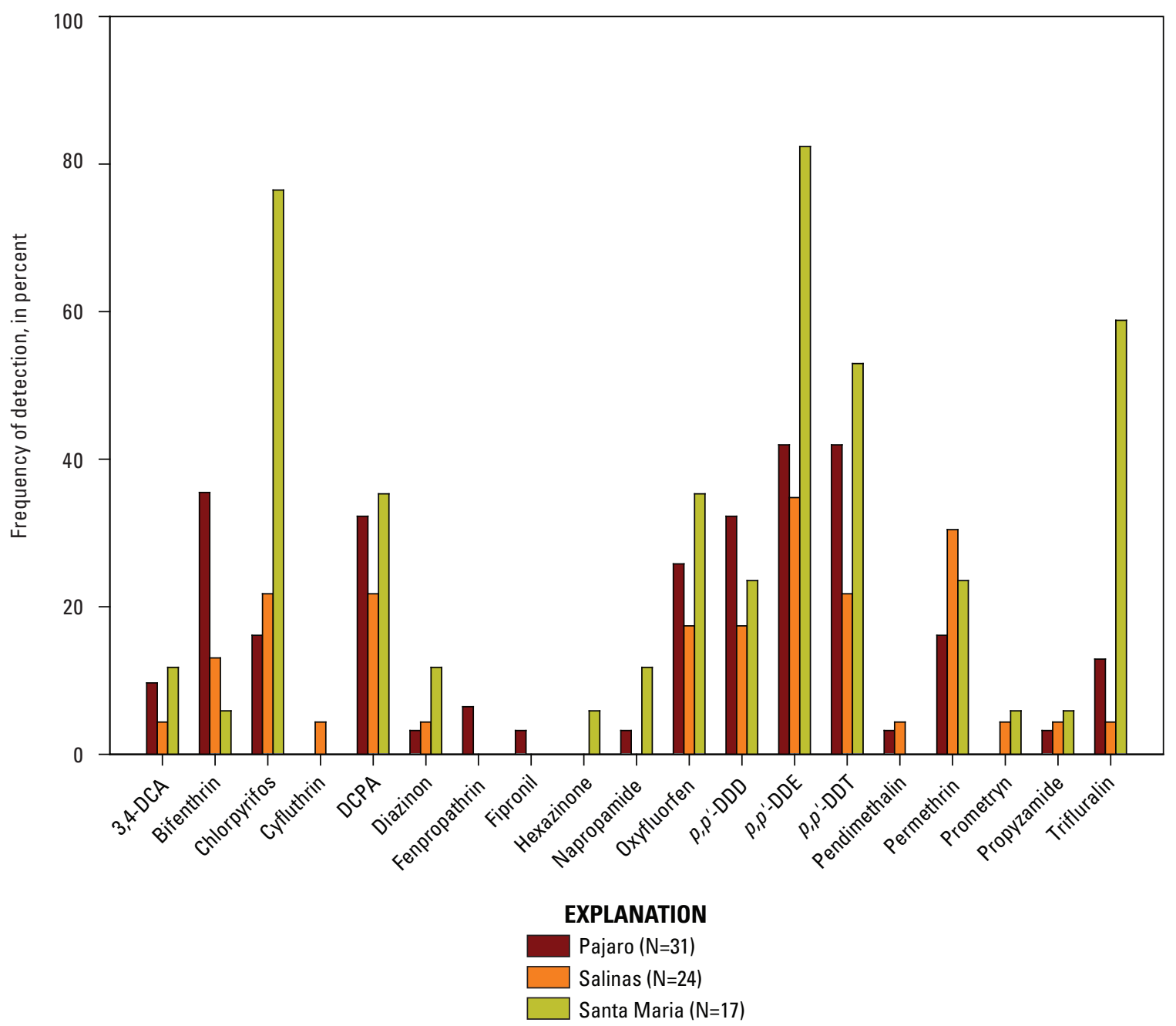

Figure 8. Frequency of detection for the pesticides in suspended sediments, as a percentage of the total number of samples in each estuary watershed, Pajaro, Salinas, and Santa Maria River estuary watersheds, California, 2008-09.. 


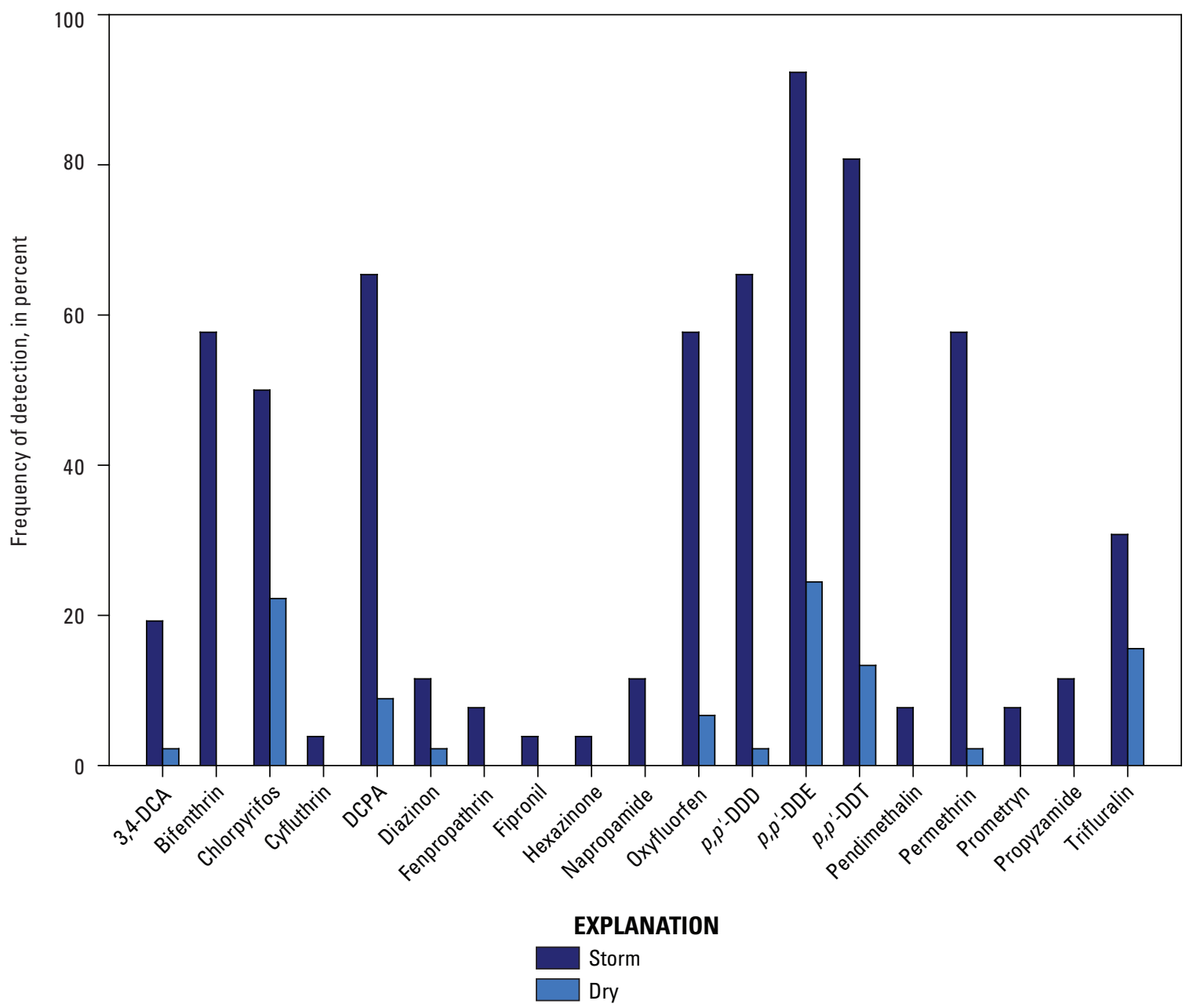

Figure 9. Frequency of detection of suspended sediment bound pesticides, as a percentage of the total number of samples by sampling period (storm versus dry season), Pajaro, Salinas, and Santa Maria River estuary watersheds, California, 2008-09..

\section{Sediment Organic Carbon and Nitrogen}

Sediment organic carbon and nitrogen were measured to provide a dataset that can be used to better understand the source(s) of a sediment sample. The percentages of organic carbon and nitrogen in suspended sediments and bed sediment samples were similar. Percent organic carbon ranged from 1.23 to 4.27 in suspended sediment, and from 0.81 to 6.75 in bed sediment. Percent organic nitrogen ranged from 0.12 to 0.54 for suspended sediment, and from 0.03 to 0.53 in bed sediment (table 13 at back of report). Organic carbon and nitrogen values in bed sediment showed no significant difference between the storm and dry seasons.

\section{Dissolved Organic Carbon}

DOC concentrations ranged from 0.4 to $17.0 \mathrm{mg} / \mathrm{L}$ in Pajaro River estuary samples, from 0.9 to $16.2 \mathrm{mg} / \mathrm{L}$ in samples from the Salinas River estuary, and from 3.8 to $41.4 \mathrm{mg} / \mathrm{L}$ in samples from the Santa Maria River estuary (tables 8-10). Average DOC concentrations for each estuary were similar throughout all the sampling events; however, higher average DOC concentrations were observed during storm events $(9.7 \mathrm{mg} / \mathrm{L})$ than the summer dry season $(5.6 \mathrm{mg} / \mathrm{L})$. The average DOC concentrations were slightly higher in the tributaries $(7.2 \mathrm{mg} / \mathrm{L})$ than the estuaries $(6.8 \mathrm{mg} / \mathrm{L})$ throughout the year.

\section{Water-Quality Parameters}

Results from the analysis of water-quality parameters (temperature, specific conductance, $\mathrm{pH}$, dissolved oxygen and turbidity) for each sampling event are shown in table 14 (at back of report). 


\section{Summary and Conclusions}

This project was designed to provide the California State Water Resources Control Board with data for an initial assessment and characterization of pesticides in three Central Coast watersheds. Currently, new farm management practices are being implemented in each watershed, so there is a need to establish baseline pesticide concentrations to determine the effects of these practices over the next several decades. In samples collected between January 2008 and October 2009, 38 different pesticides were detected in water and 22 pesticides were detected in sediments. The types of pesticides detected were similar between estuaries, and the maximum dissolved concentrations in water samples ranged from at or below method detection limits to $36,000 \mathrm{ng} / \mathrm{L}$. Boscalid, a carboxamide fungicide, was not only the most frequently detected pesticide in all watersheds but was detected at the highest maximum concentration. Detection frequencies for most pesticides were higher in the Santa Maria River estuary watershed than the Pajaro and Salinas River estuary watersheds. A greater number of dissolved pesticides were detected during storm events than the dry season, and concentrations were often at their maximums during storm events as well. Maximum concentrations of pesticides in bed and suspended sediments ranged from less than their respective method detection limits to 234 and $549 \mu \mathrm{g} / \mathrm{kg}$, respectively. In bed sediment samples collected from the three estuaries, $p, p^{\prime}$-DDE, the aerobic breakdown product of $p, p^{\prime}$-DDT, was detected most frequently, and was one of the only compounds detected in more than 50 percent of the samples. In suspended sediment samples, no compound was detected in more than 50 percent of the samples during the dry season, however eight pesticides were detected in more than 50 percent of the samples during storm events.

\section{Acknowledgments}

The authors acknowledge Jason Cooper, Kristi Jones and Ryan Todd of the USGS for their many hours of sampling and laboratory work. The authors also acknowledge our colleagues and collaborators on this project, Bryn Phillips, Brian Anderson, John Hunt and Katie Siegler of the University of California at Davis Marine Pollution Studies Laboratory.

We also thank the Guadalupe Nipomo Dunes National Wildlife Refuge and Mary Adams of the Central Coast Regional Water Quality Control Board for support of the project. This project was funded by the California State Resources Control Board (Contract \# 06-652-553-0) and the U.S. Geological Survey Federal-State Cooperative Program.

\section{References Cited}

Anderson, B.S., Hunt, J.W., Phillips, B.M., Nicely, P.A., de Vlaming, V., Connor, V., Richard, N., and Tjeerdema, R.S., 2003, Integrated assessment of the impacts of agricultural drainwater in the Salinas River (California, USA): Environmental Pollution, v. 124, p. 523-532.

Anderson, B.S., Phillips, B.M., Hunt, J.W., Worcester, K., Adams, M., Kapellas, N., and Tjeerdema, R.S., 2006, Evidence of pesticide impacts in the Santa Maria River watershed, California, USA: Environmental Toxicology and Chemistry, v. 25, no. 4, p. 1160-1170.

Bird, S.M., Fram, M.S., and Crepeau, K.L., 2003, Method of analysis by the U.S. Geological Survey California District Sacramento Laboratory-Determination of dissolved organic carbon in water by high temperature catalytic oxidation, method validation and quality control practices: U.S. Geological Survey Open-File Report 03-366, 14 p.

California Department of Pesticide Regulation, 2009, Pesticide use reporting system: Pesticide use data for 2008, [Digital data]: California Department of Pesticide Regulation.

Crepeau, K.L., Kuivila, K.M., and Bergamaschi, B.A., 2000, Method analysis and quality assurance practices for determination of pesticides in water by solid-phase extraction and capillary column gas chromatography/mass spectrometry at the U.S. Geological Survey California District Organic Chemistry Laboratory, 1996-99: U.S. Geological Survey Open File Report 2000-229, 19 p.

Hladik, M.L and Kuivila, K.M., 2009, Assessing the occurrence and distribution of pyrethroids in water and suspended sediments: Journal of Agriculture and Food Chemistry, v. 57, p. 9079-9085.

Hladik, M.L., Smalling, K.L., and Kuivila, K.M., 2008, A multi-residue method for the analysis and pesticides and pesticide degradates in water using Oasis HLB solid phase extraction and gas chromatography-ion trap mass spectrometry: Bulletin of Environmental Contamination and Toxicology, v. 80, p. 139-144.

Horowitz, A.J., Elrick, K.A., and Hooper, R.C., 1989, A comparison of instrumental dewatering methods for the separation and concentration of suspended sediments for subsequent trace element analysis: Hydrological Processes, v. 2, p. 163-184.

Hunt, J.W., Anderson, B.S., Phillips, B.M., Tjeerdema, R.S., Puckett, H.M., and de Vlaming, V., 1999, Patterns of aquatic toxicology in an agriculturally dominated coastal watershed in California: Agriculture Ecosystems and Environment, v. 75, p. 75-91. 
LeBlanc, L.A., Schroeder, R.A., Orlando, J.L. and Kuivila, K.A., 2004, Occurrence, distribution and transport of pesticides, trace elements and selected inorganic constituents into the Salton Sea Basin, California, 2001-2002: U.S. Geological Survey Scientific Investigations Report 2004-5117, 40 p.

Natural Resources Conservation Service, 2009, Watershed Boundary Dataset. Digital data accessed 12/10/2009, at http://datagateway.nrcs.usda.gov

Potter, B.B., and Wimsatt, J.C., 2005, Measurement of total organic carbon, dissolved organic carbon and specific UV absorbance at $254 \mathrm{~nm}$ in source water and drinking water: Washington, DC, U.S. Environmental Protection Agency, EPA/600/R-05/055, Method 415.3.

Rantz, S.E., and others, 1982, Measurement and computations of stream flow. Volume 1. Measurement of stage and discharge: U.S. Geological Survey Water Supply Paper 2175.

Smalling, K.L., and Kuivila, K.M., 2008, Multi-residue method for the analysis of 85 current-use and legacy pesticides in bed and suspended sediments: Journal of Chromatography A, v. 1210, p. 8-18.

Smalling, K.L., Orlando, J.L. and Kuivila, K.M., 2005, Analysis of pesticides in surface water and sediment from Yolo Bypass, California, 2004-2005: U.S. Geological Survey Scientific Investigations Report 2005-5220, 20 p.
State Water Resources Control Board, 2002, Clean water act section 303(d) list of water quality limited segments: State Water Resources Control Board, accessed June 2010 at http://www.swrcb.ca.gov/water_issues/programs/ tmdl/303d lists.shtml.

U.S. Environmental Protection Agency, 1992, Definition and procedure for the determination of the method detection limit-Revision 1.11: Code of Federal Regulations 40, Protection of the Environment, CFR Part 136, Appendix B, p. 565-567.

U.S. Geological Survey, 2001, National Land Cover Dataset: Digital data, accessed January 2007, at http://www.mrlc. gov/.

U.S. Geological Survey, 2006, Collection of water samples (ver. 2.0): U.S. Geological Survey Techniques of WaterResoures Investigations, book 9 chap A4, 231 p.

Wilde, F.D., Radtke, D.B., Gibs, J., and Iwatsubo, R.T., 1998. National field manual for the collection of waterquality data: U.S. Geological Survey Techniques of WaterResources Investigations, Selection of Equipment for Water Sampling, book 9, chap. A28. 


\section{Tables 8-14}




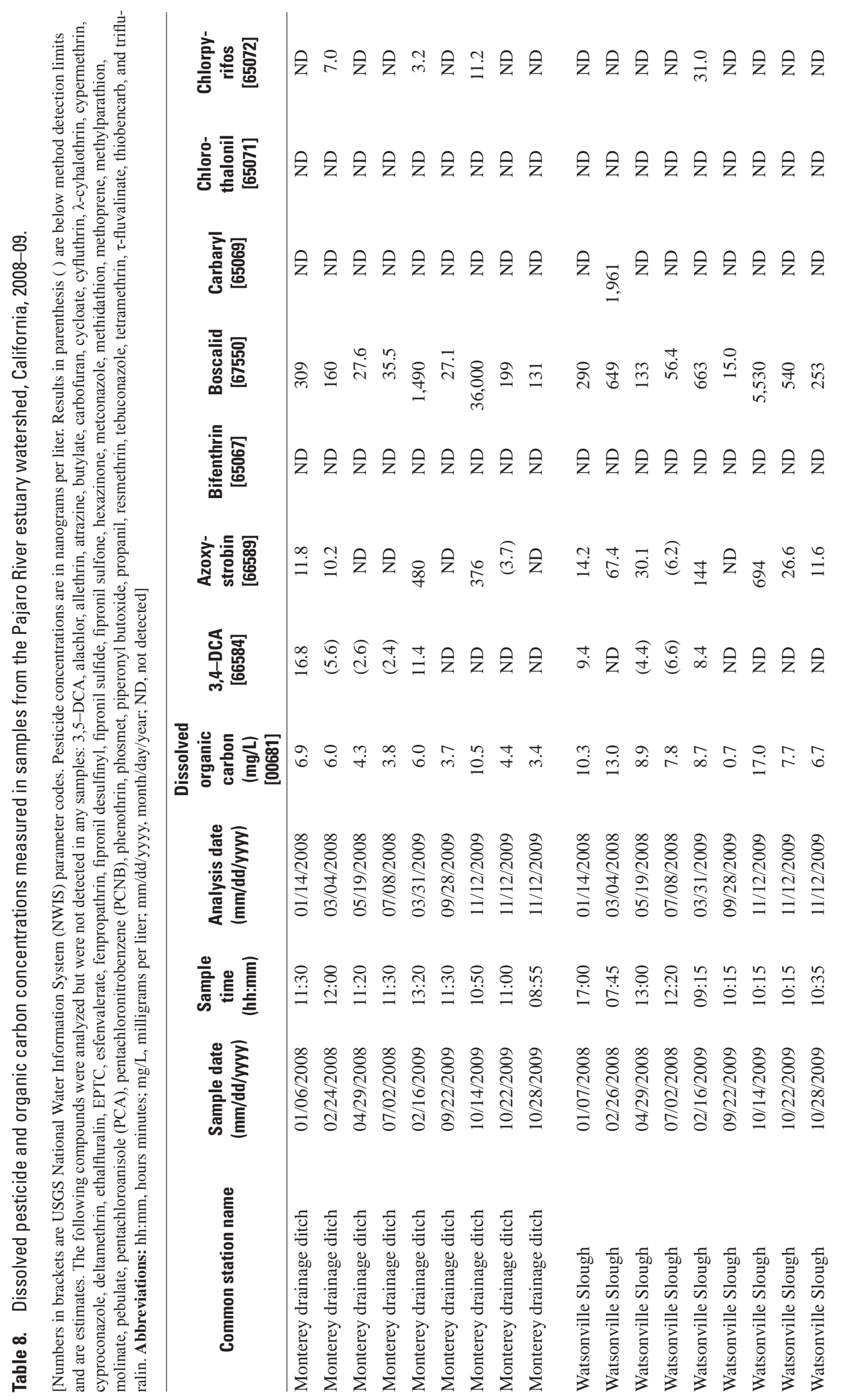




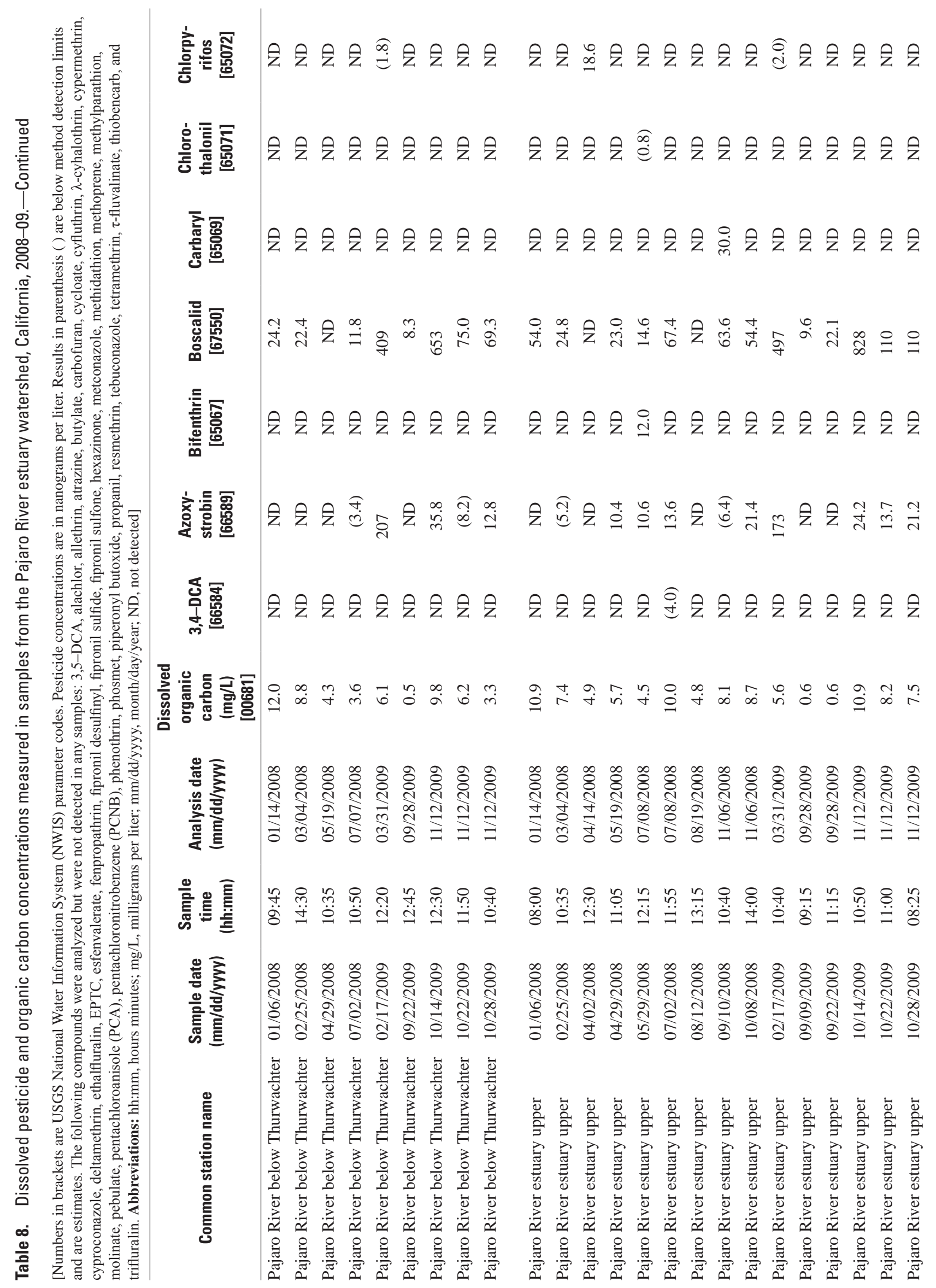




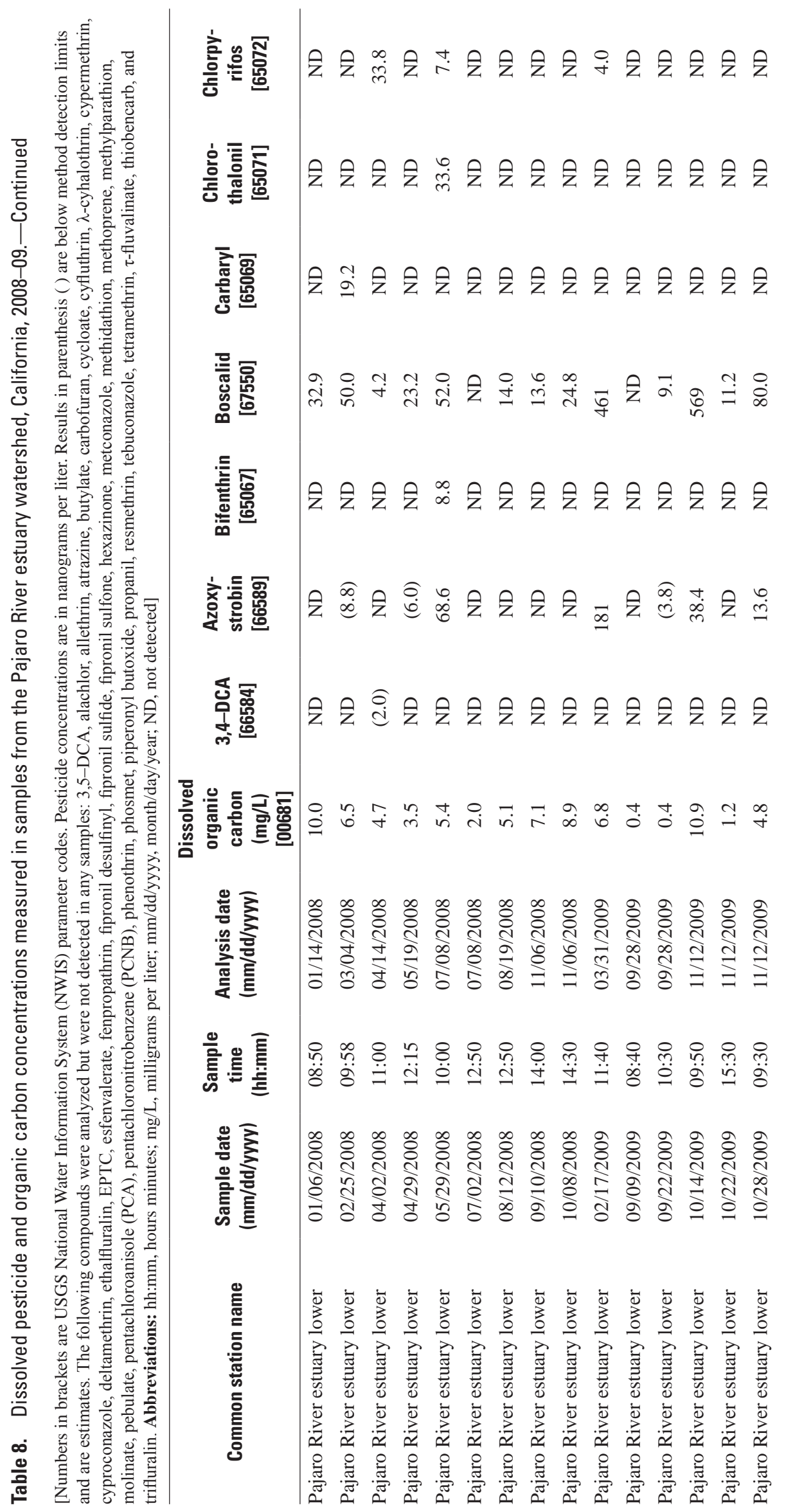




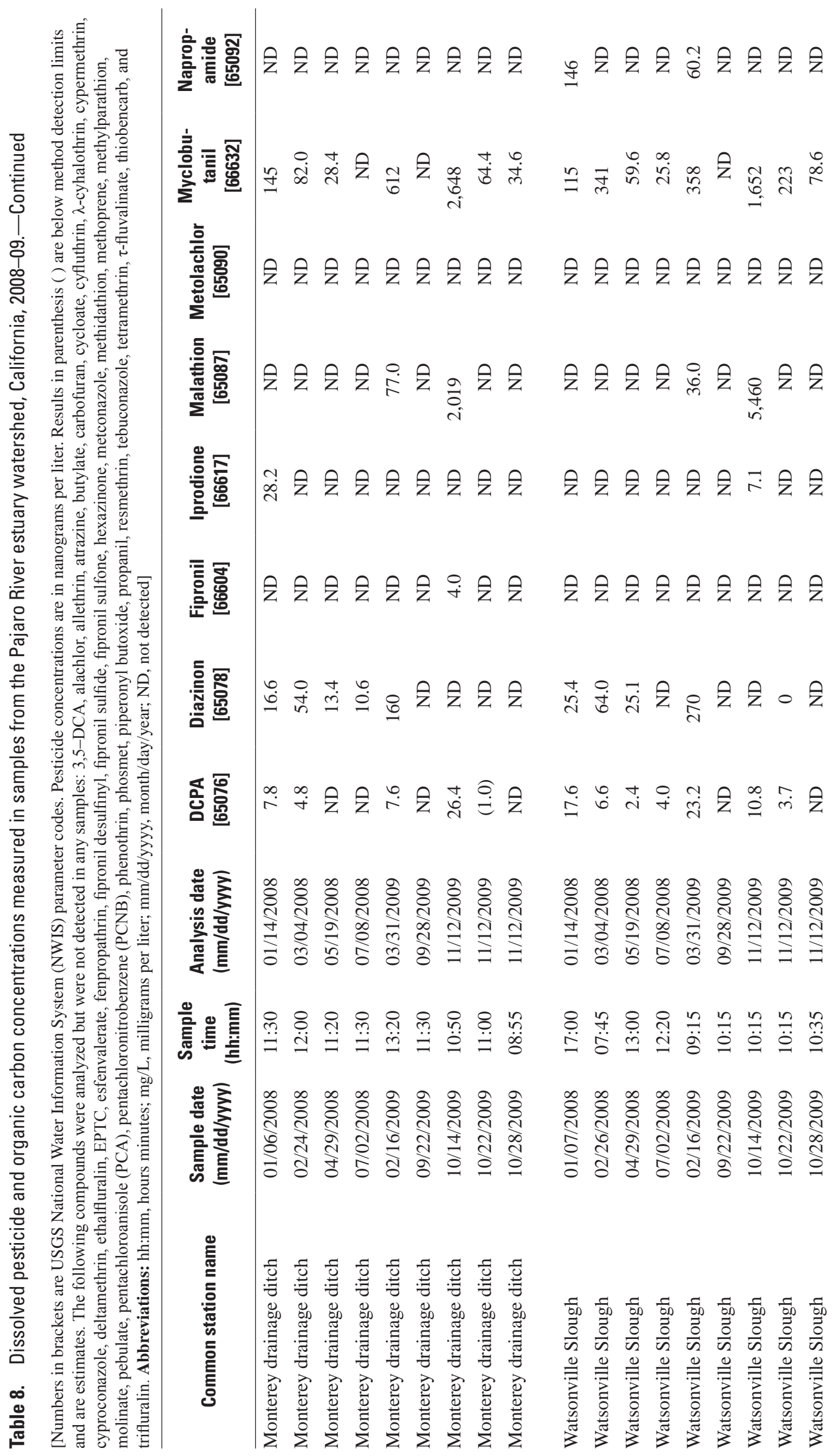




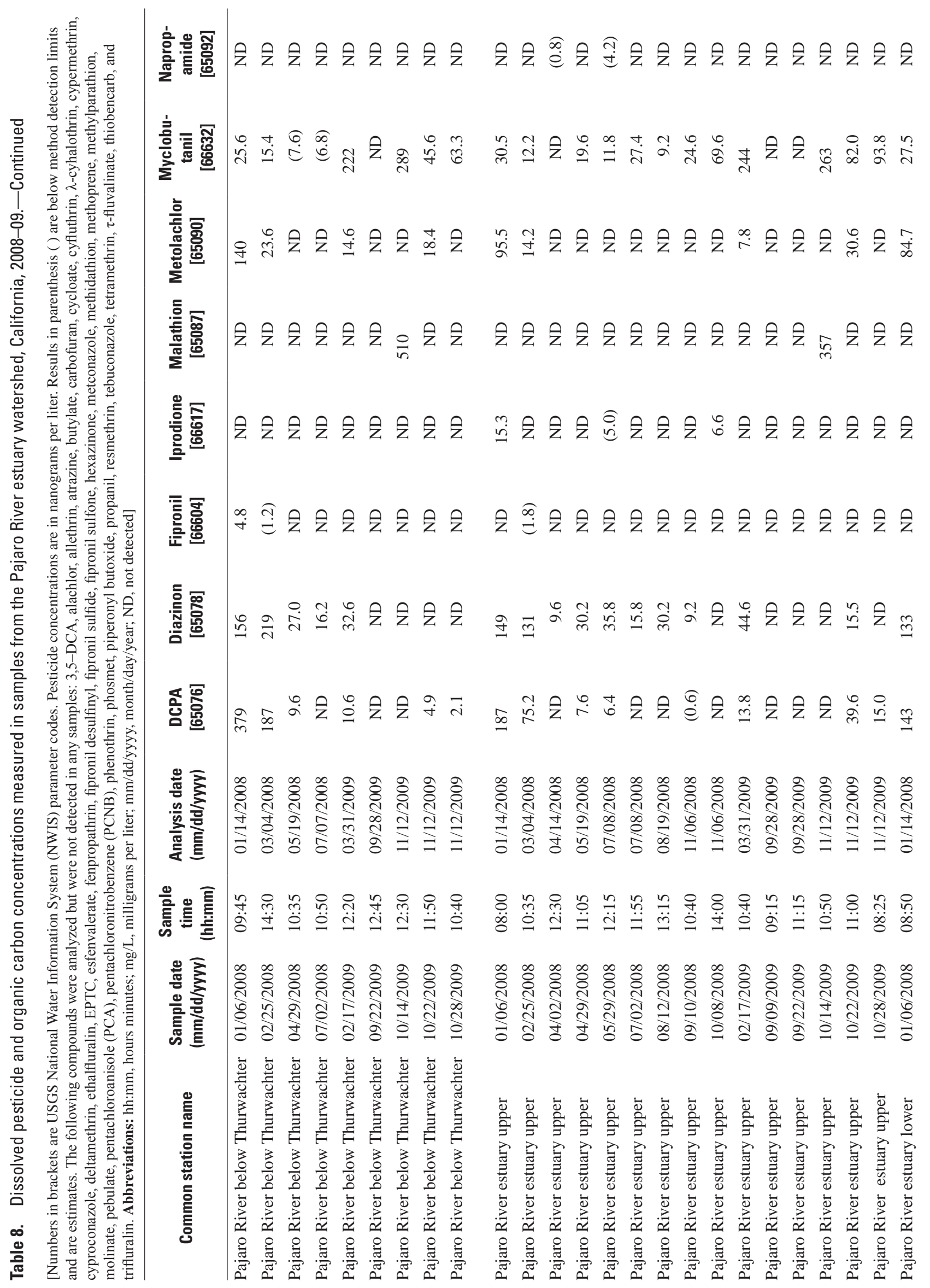




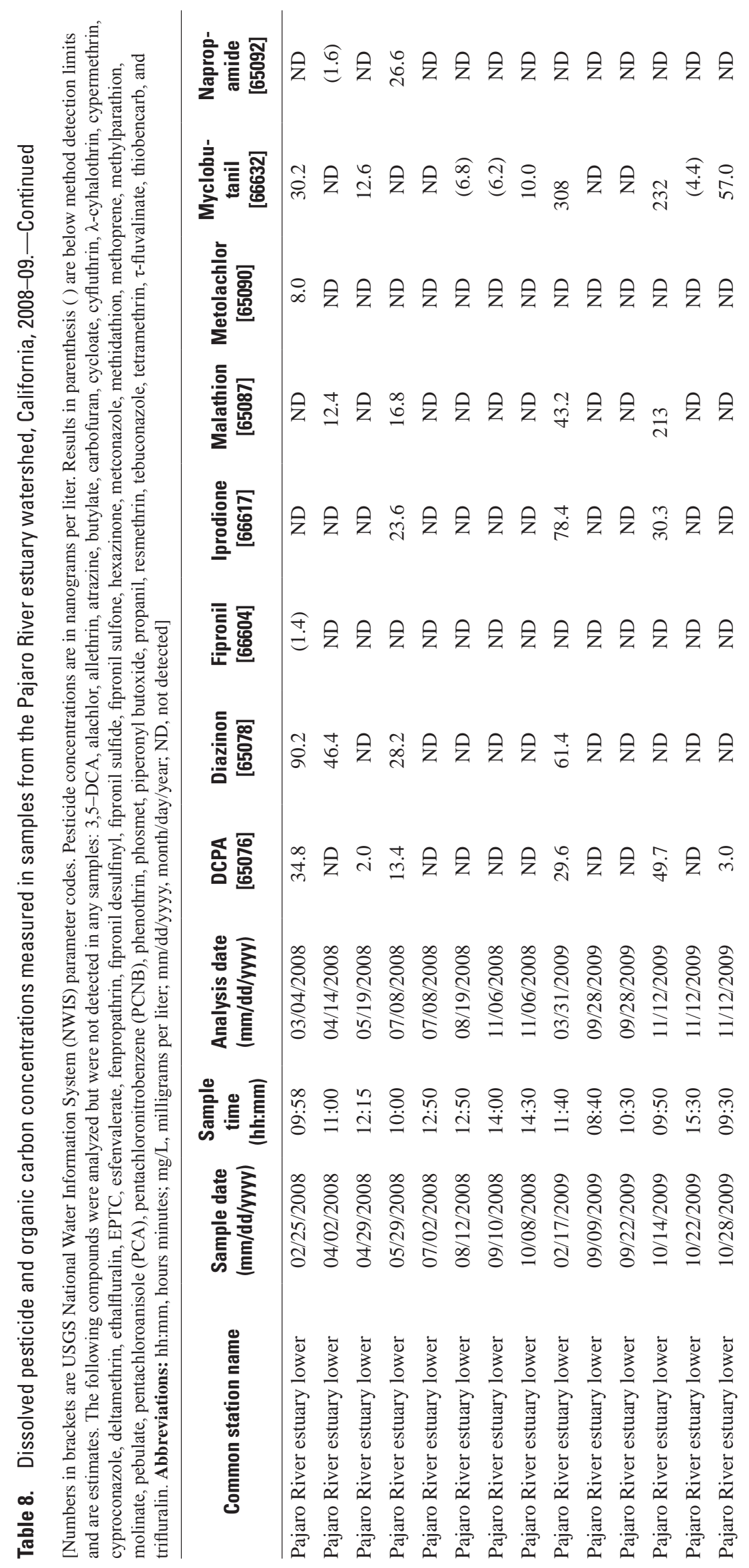




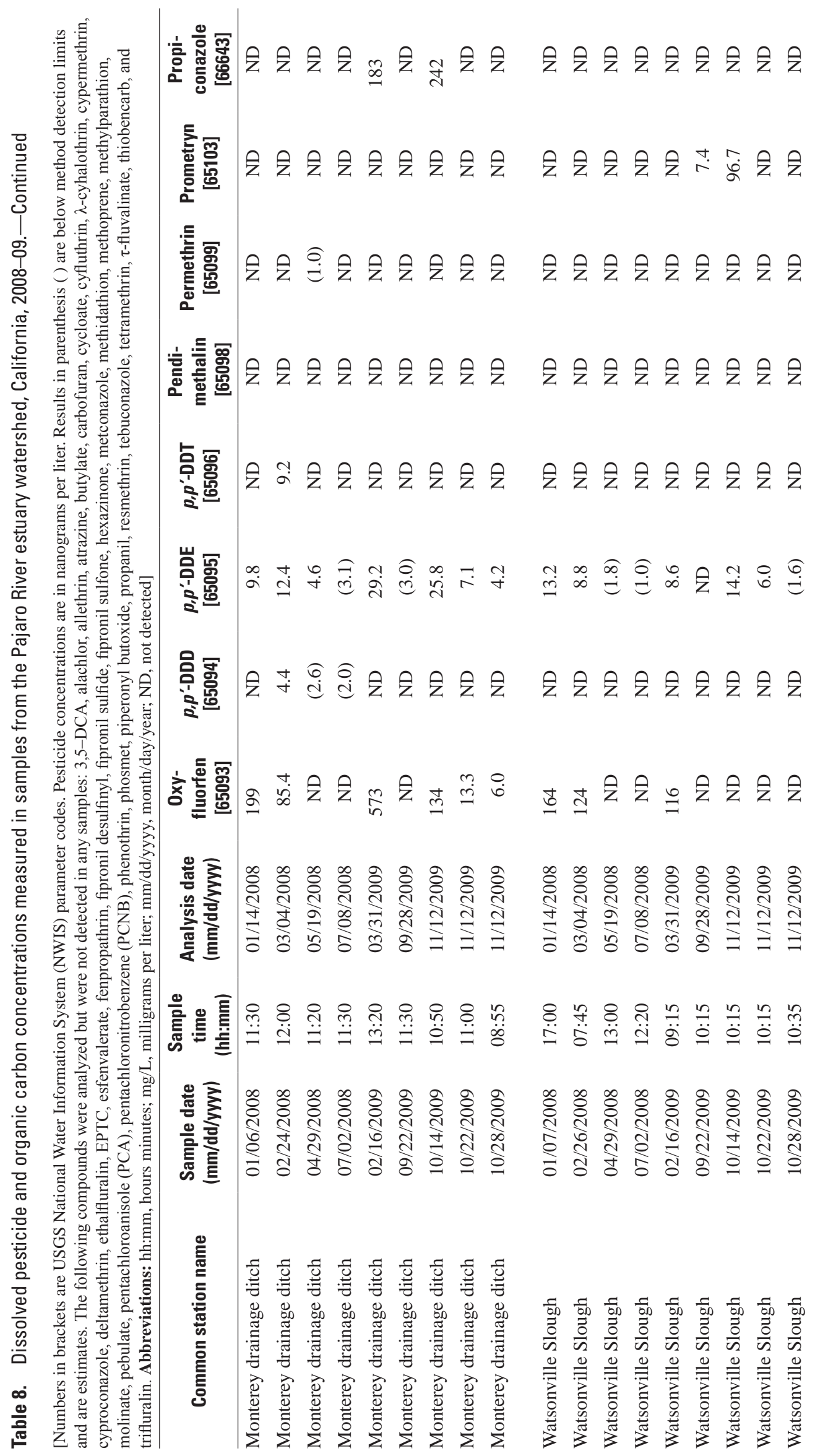




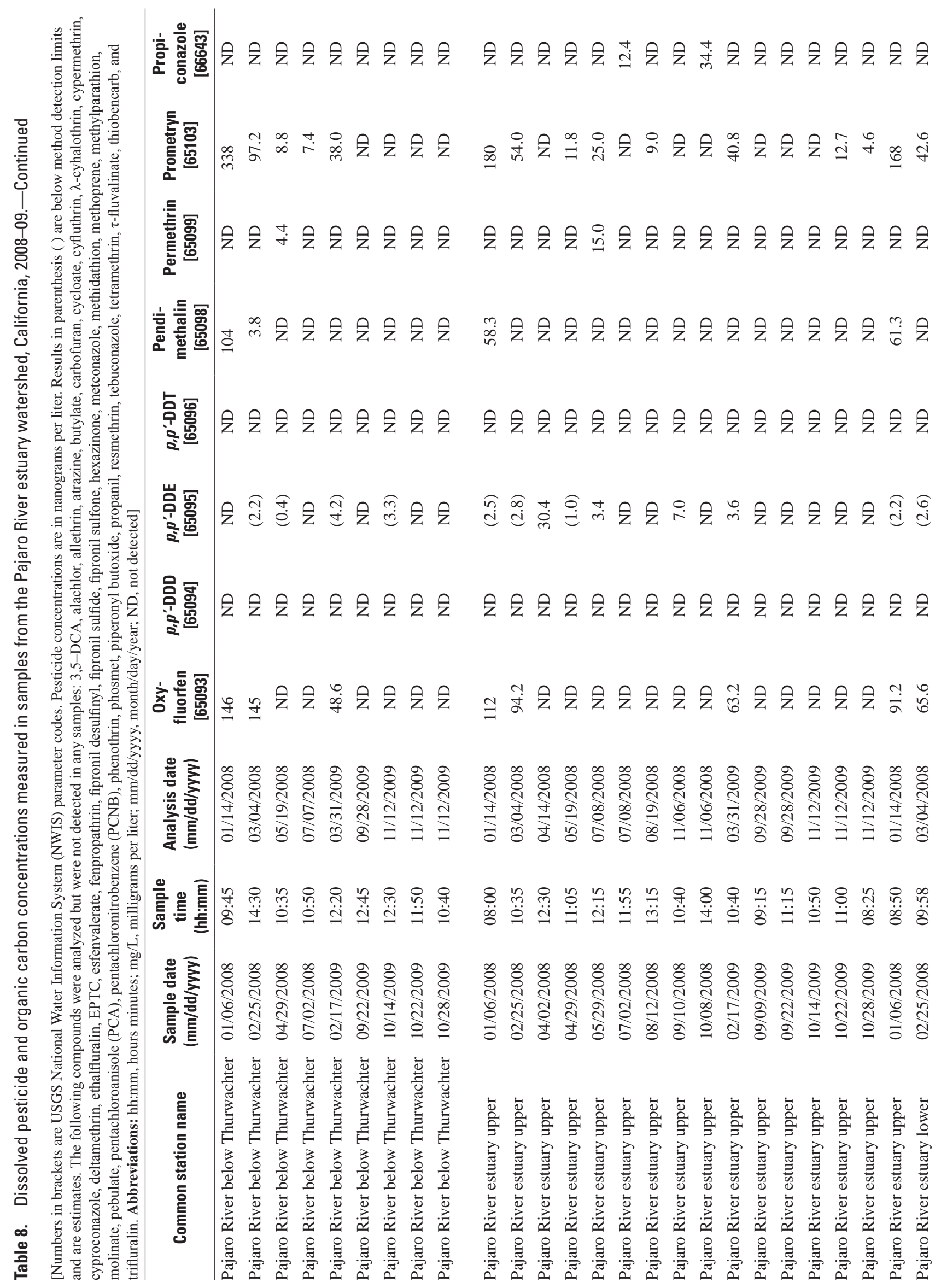




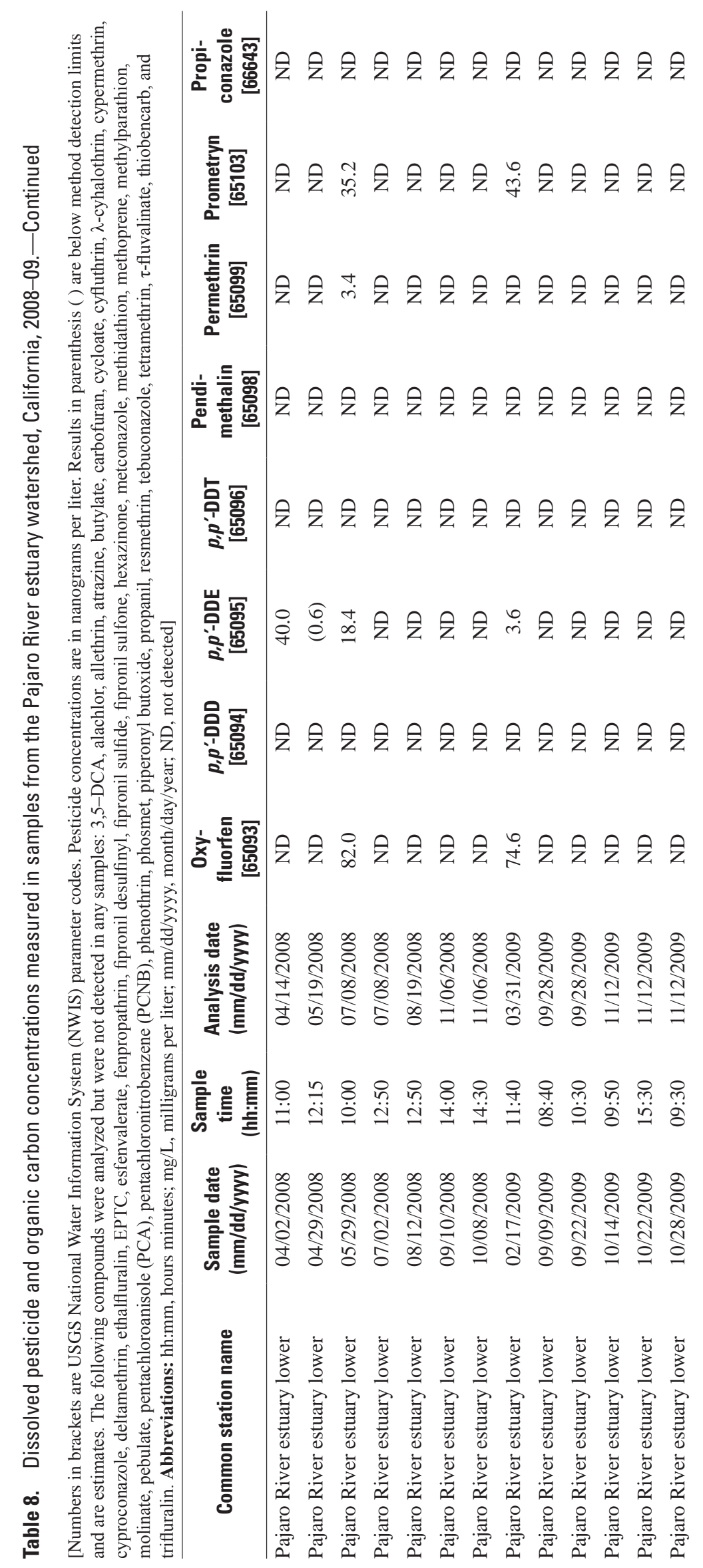




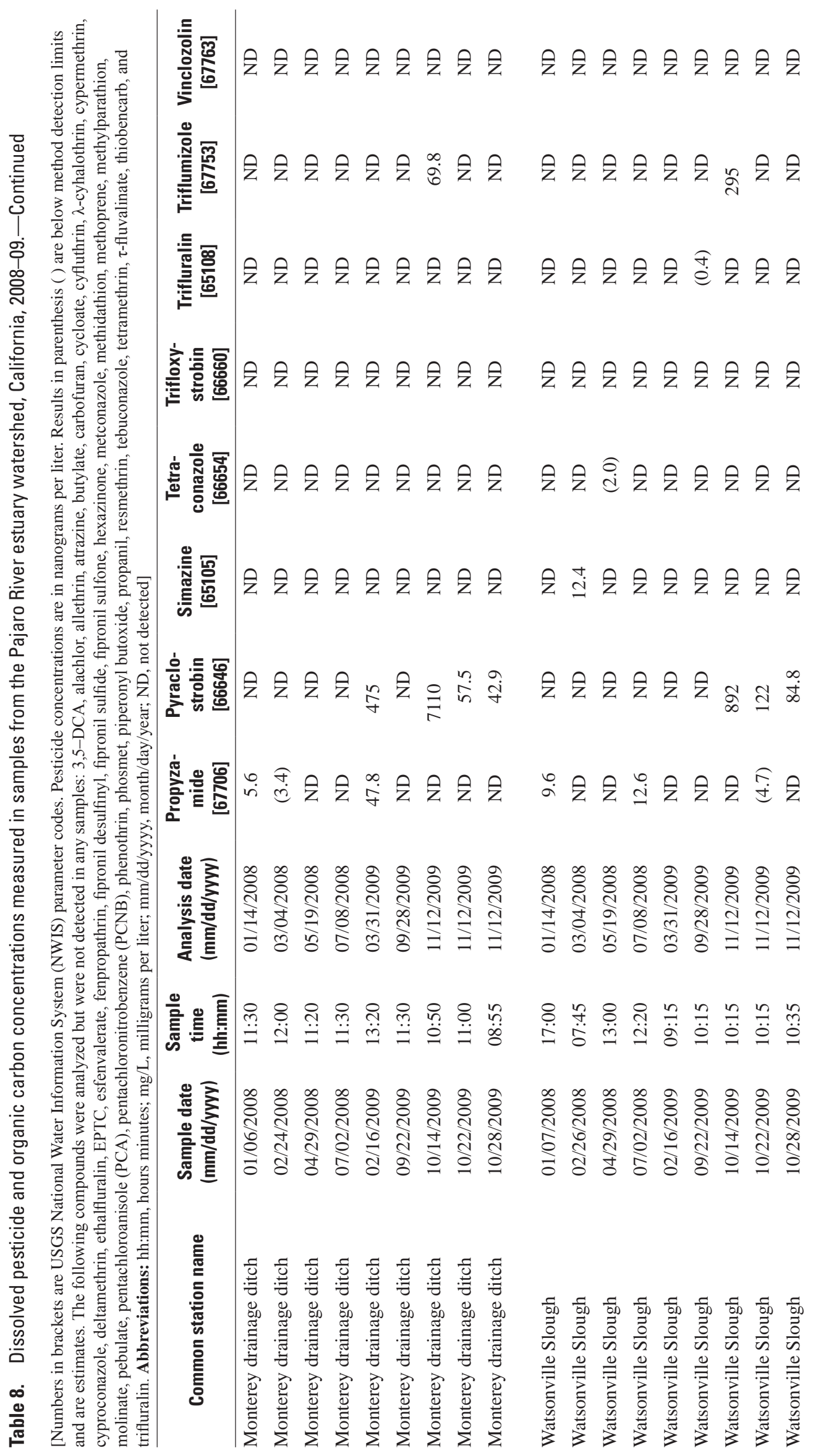




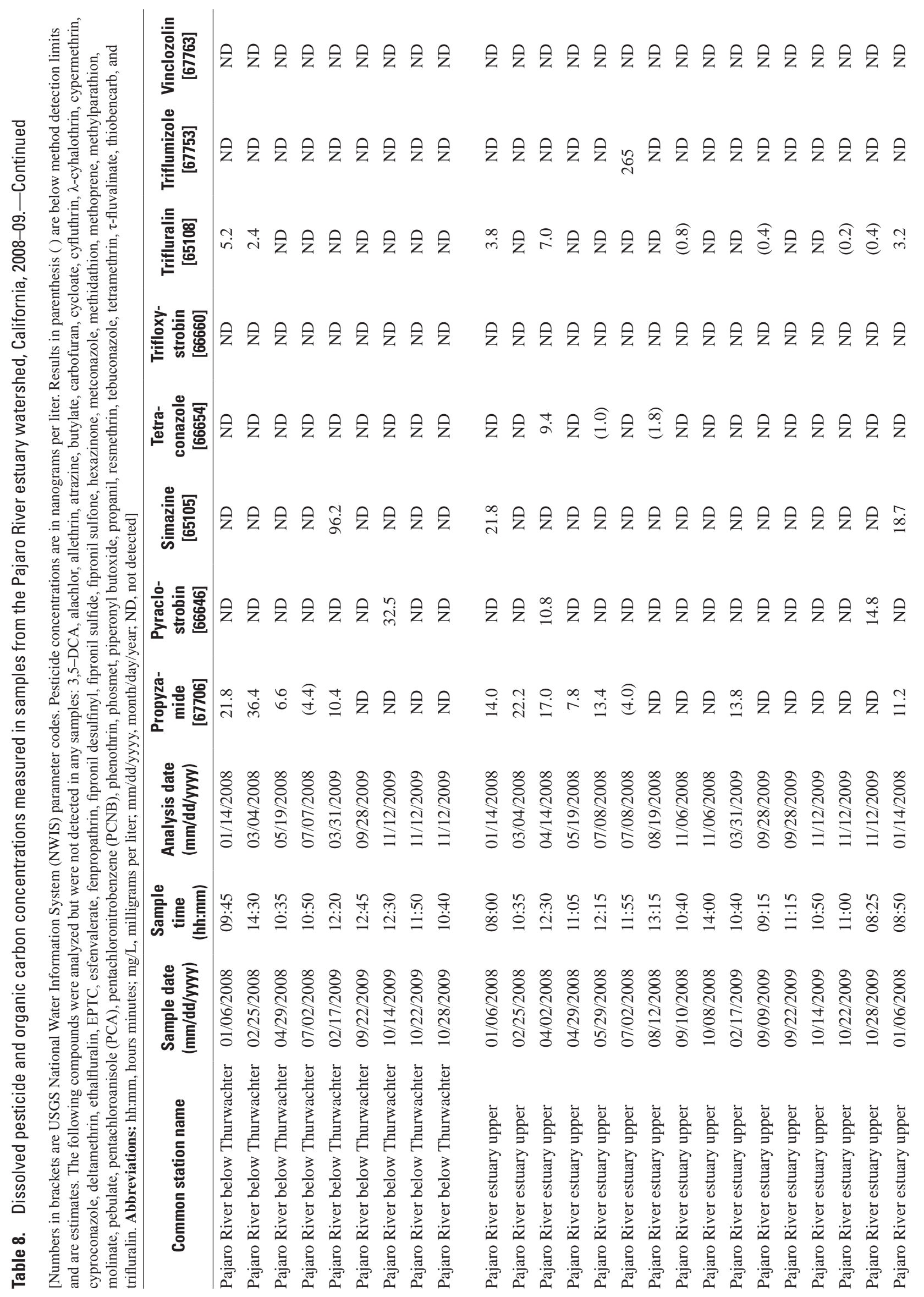




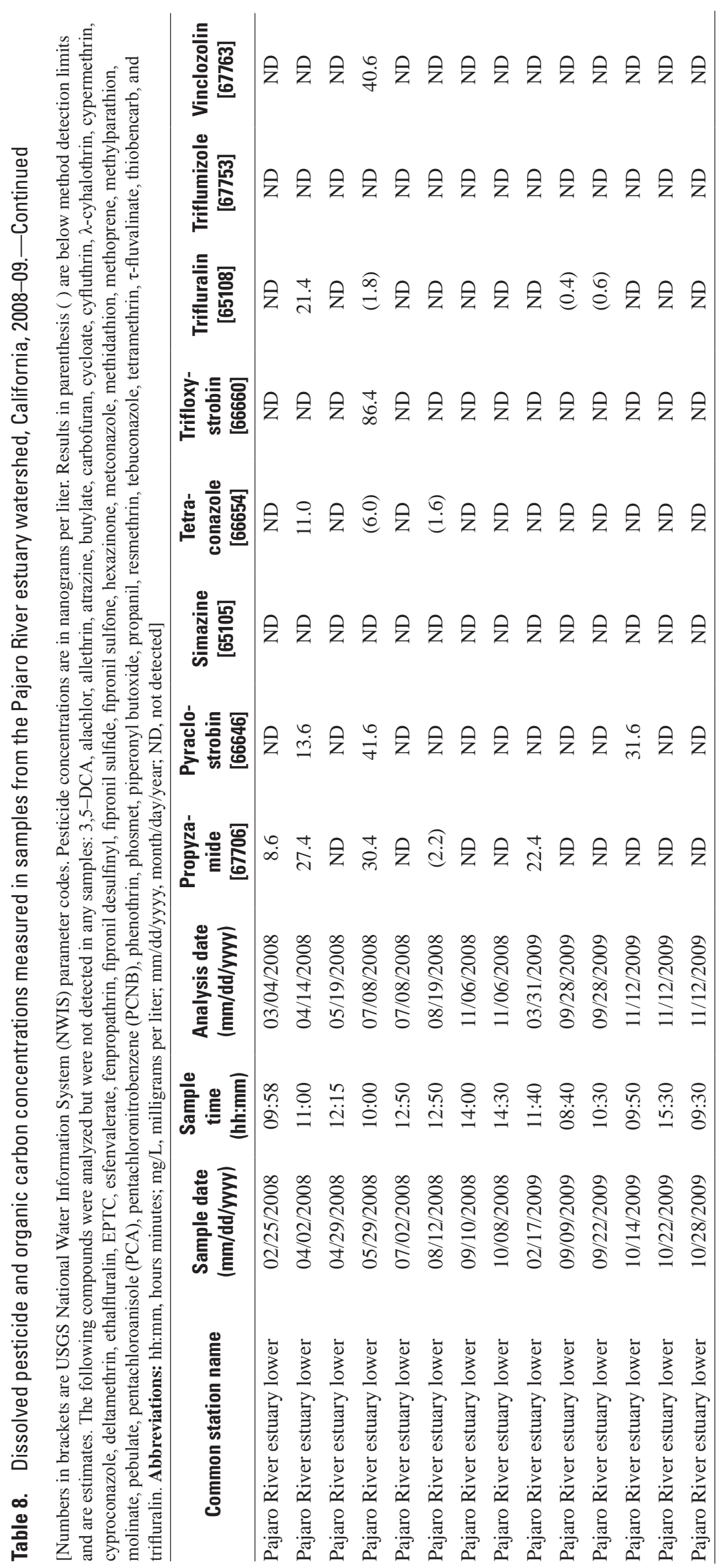




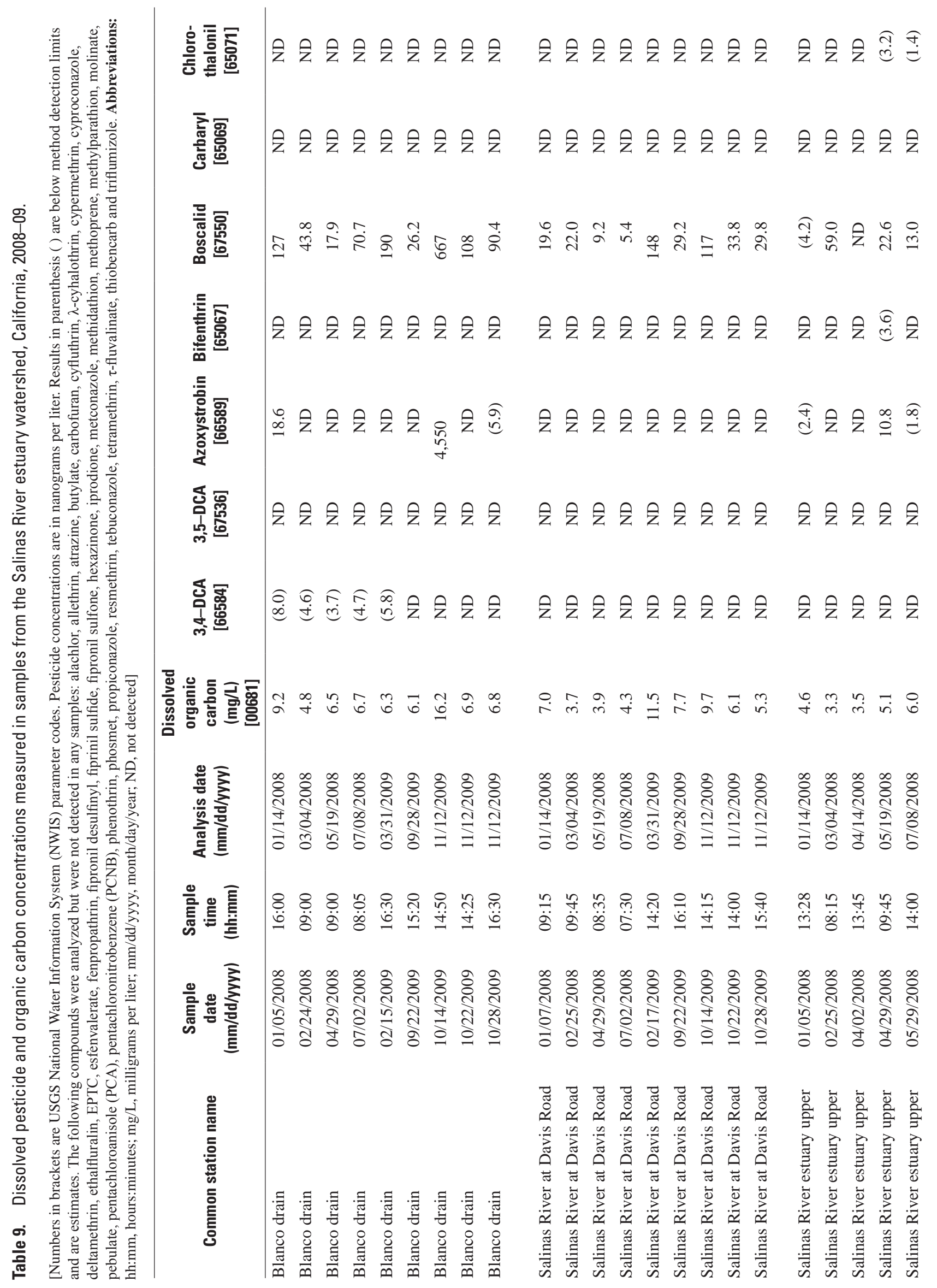


Table 9

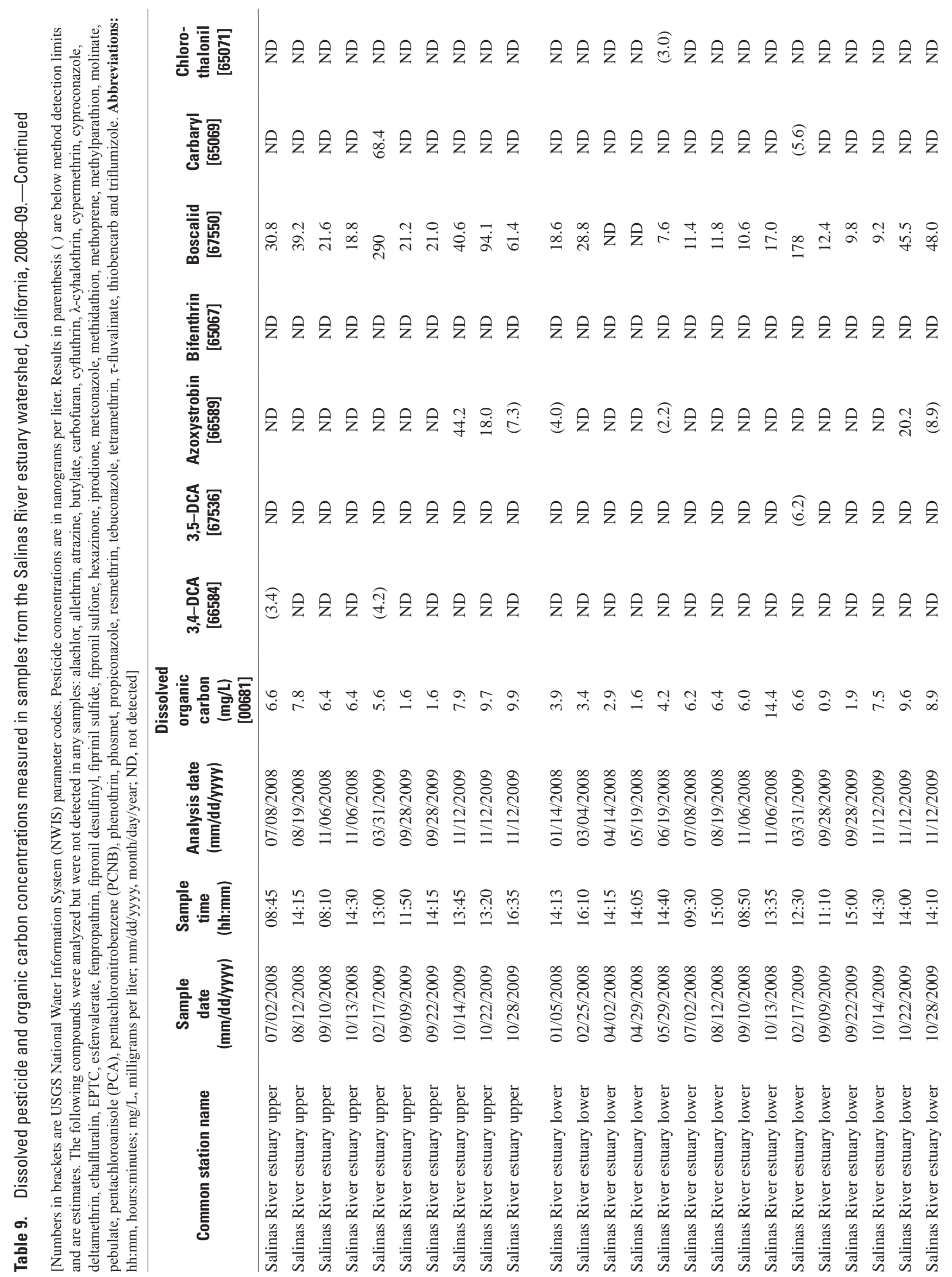




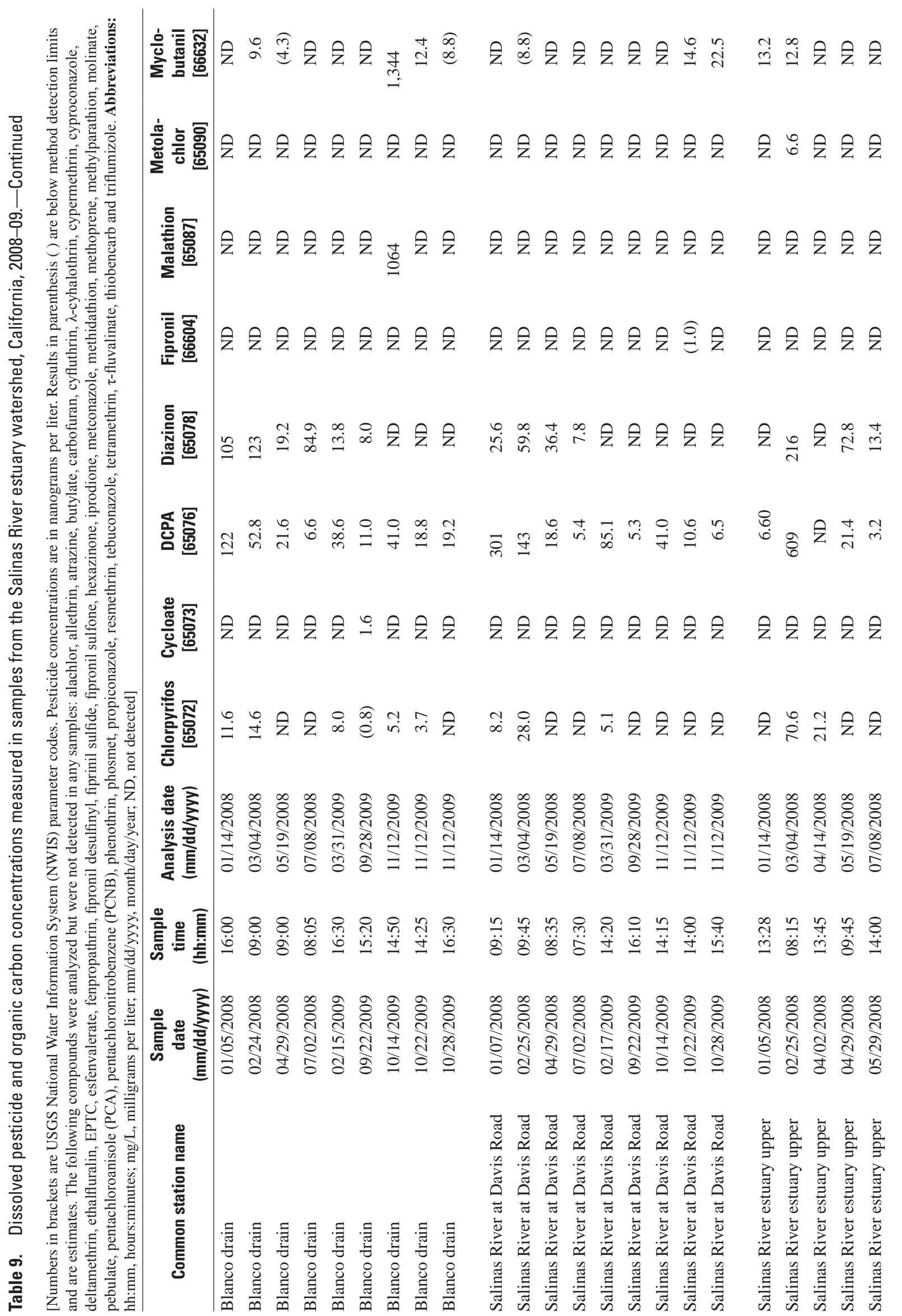




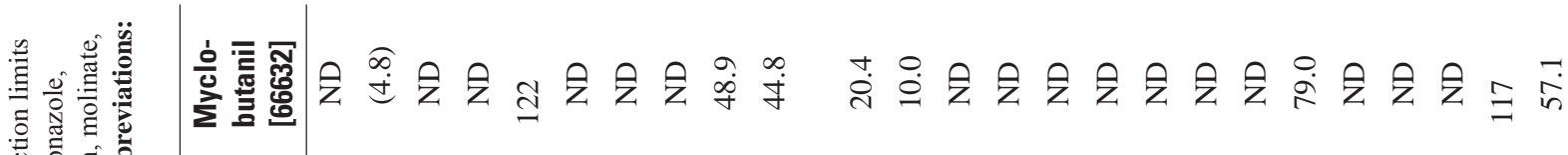

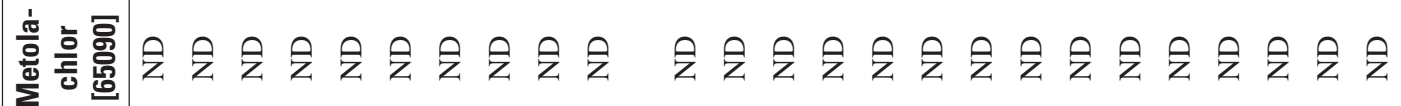

营害吉

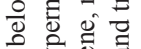

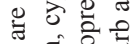

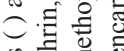

क응

청의

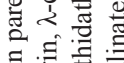

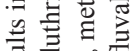

氙零

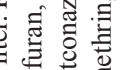

む車

ขึ ฮี

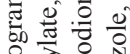

苋昰

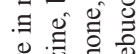

츄

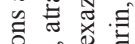

氖吉志

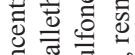

过泀青

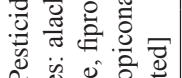

过

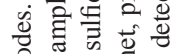

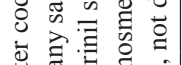

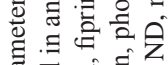

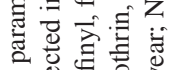

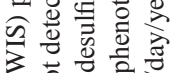

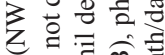

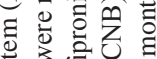

के

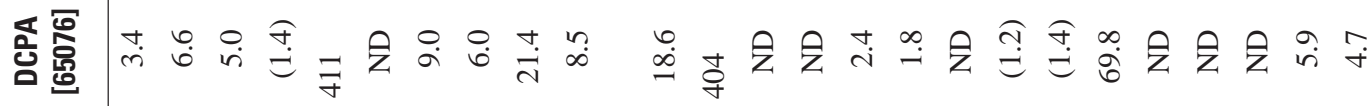

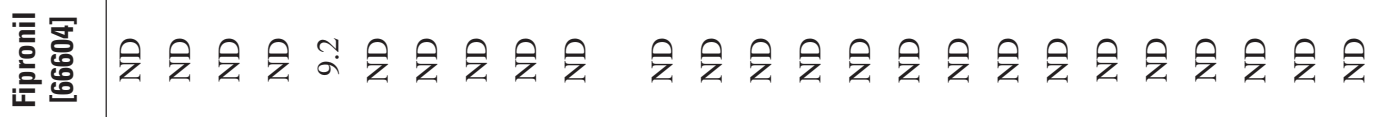

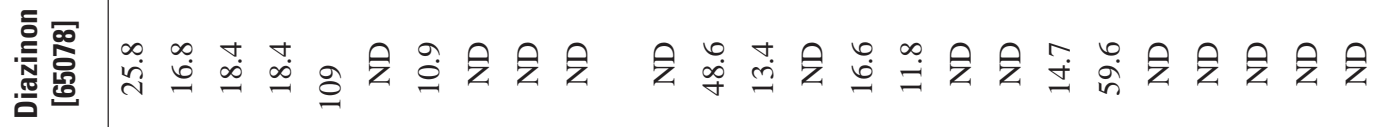

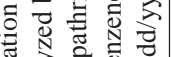

을 을

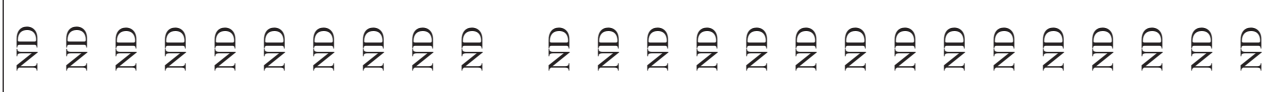

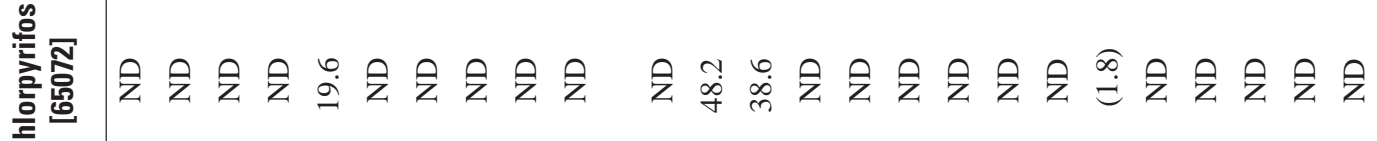

营

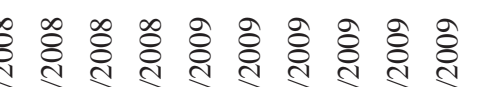

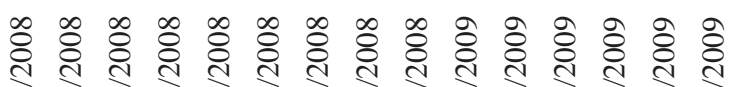

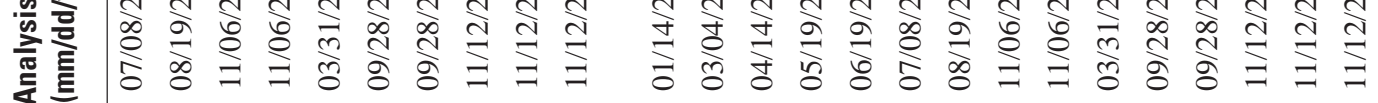

층 중

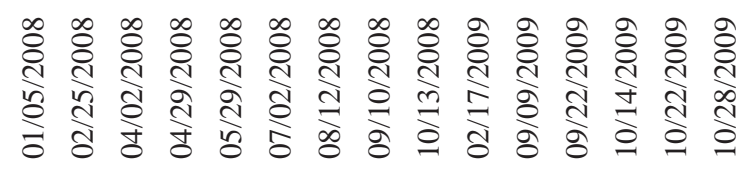

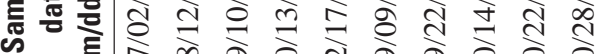

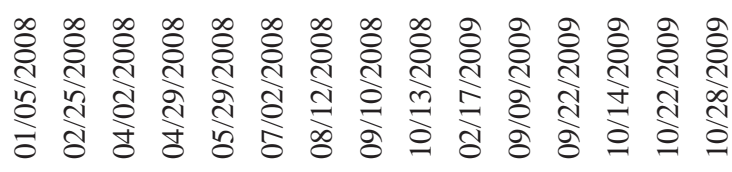

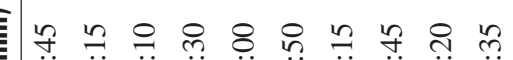

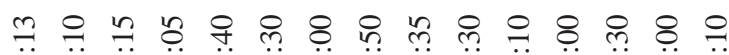

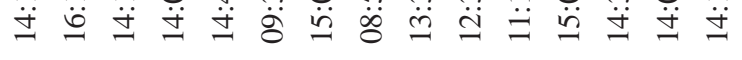

芯芯芯芯芯芯芯芯芯芯

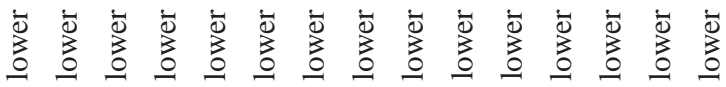

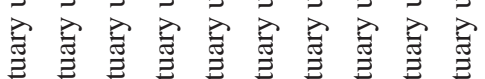

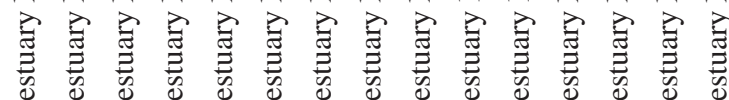

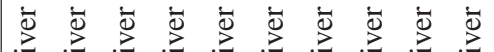

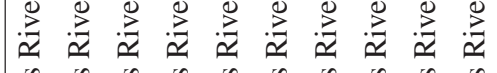

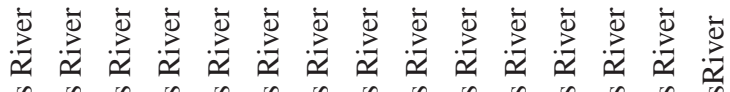

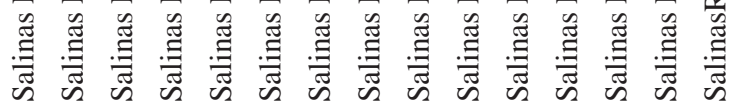




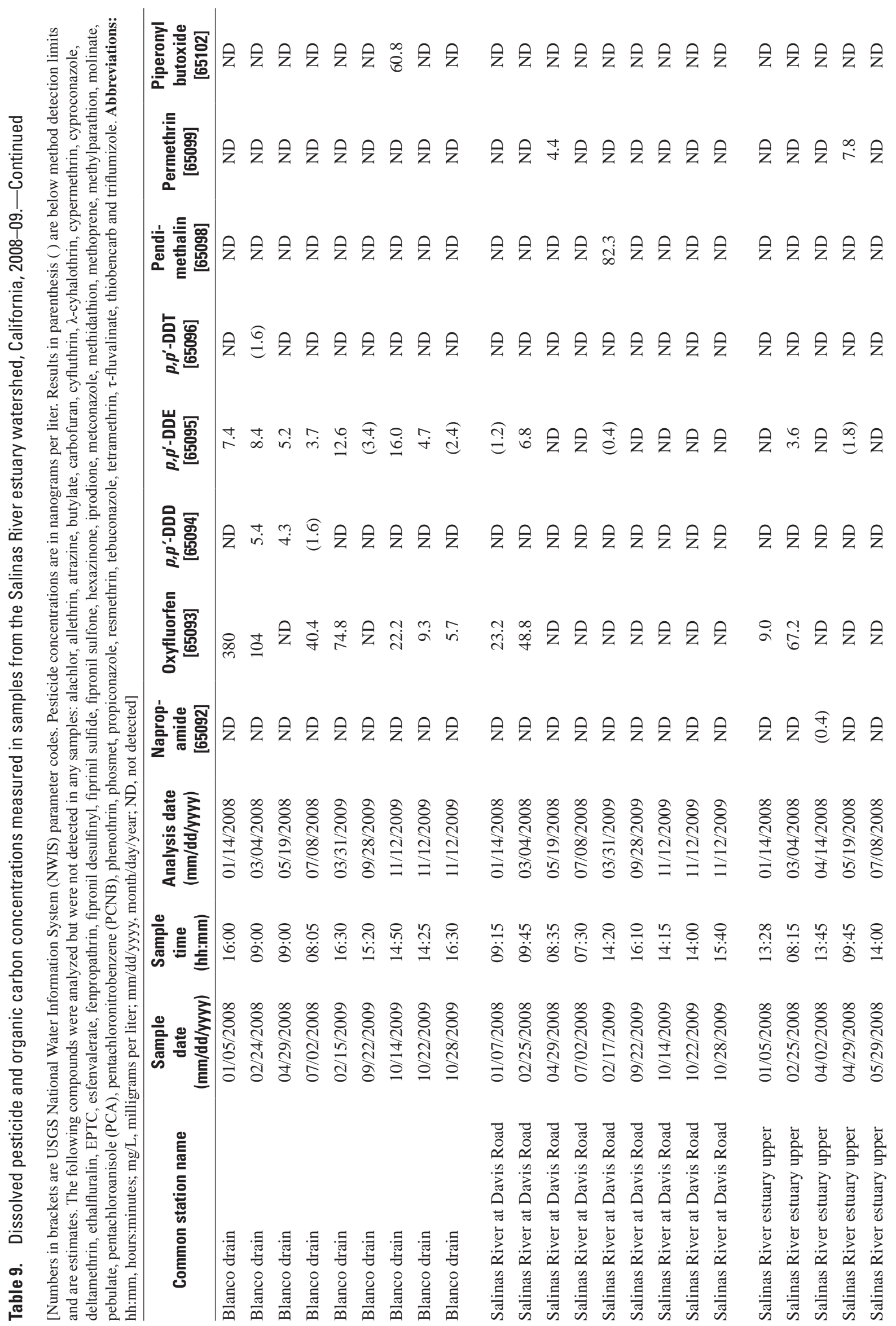




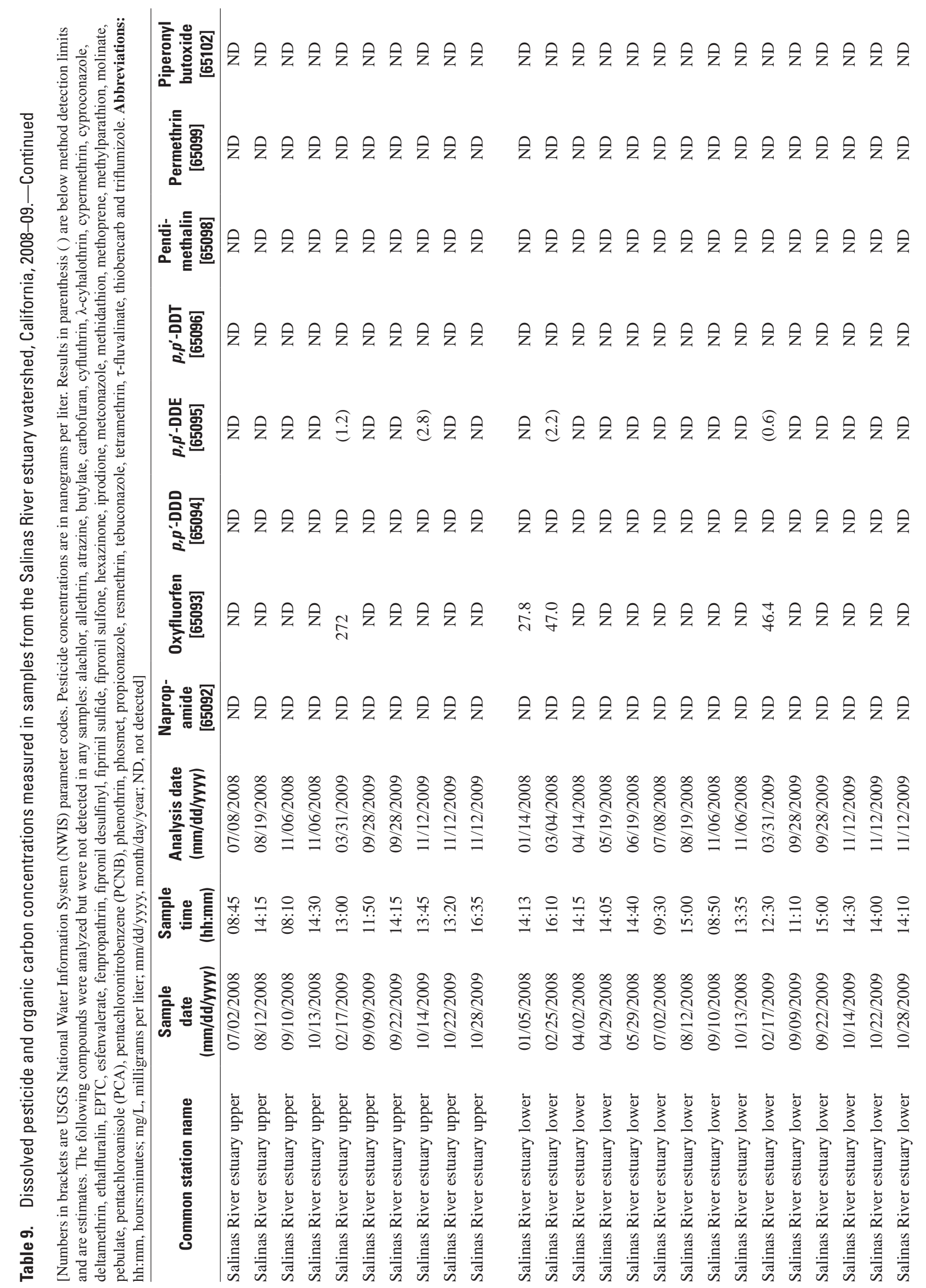




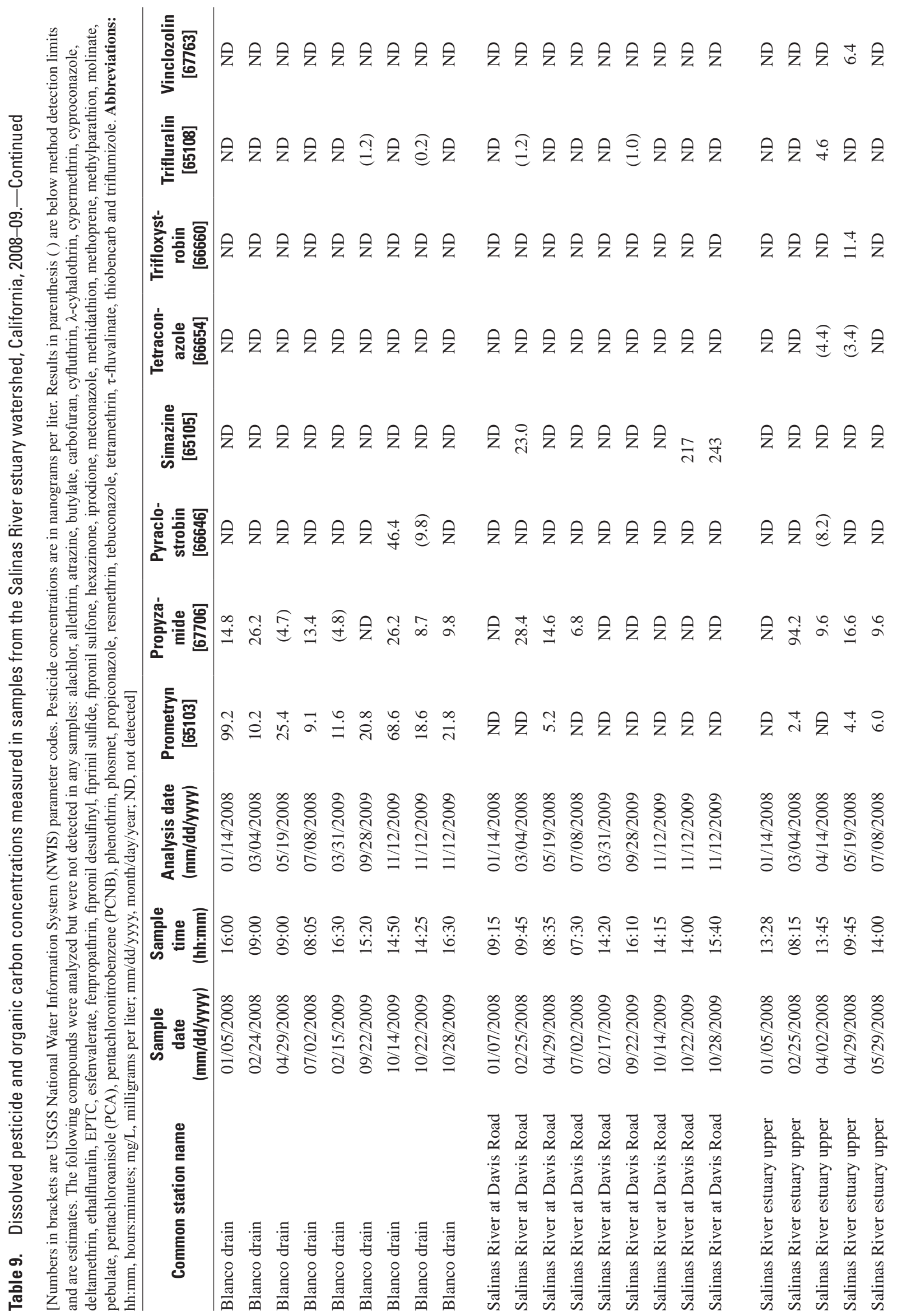




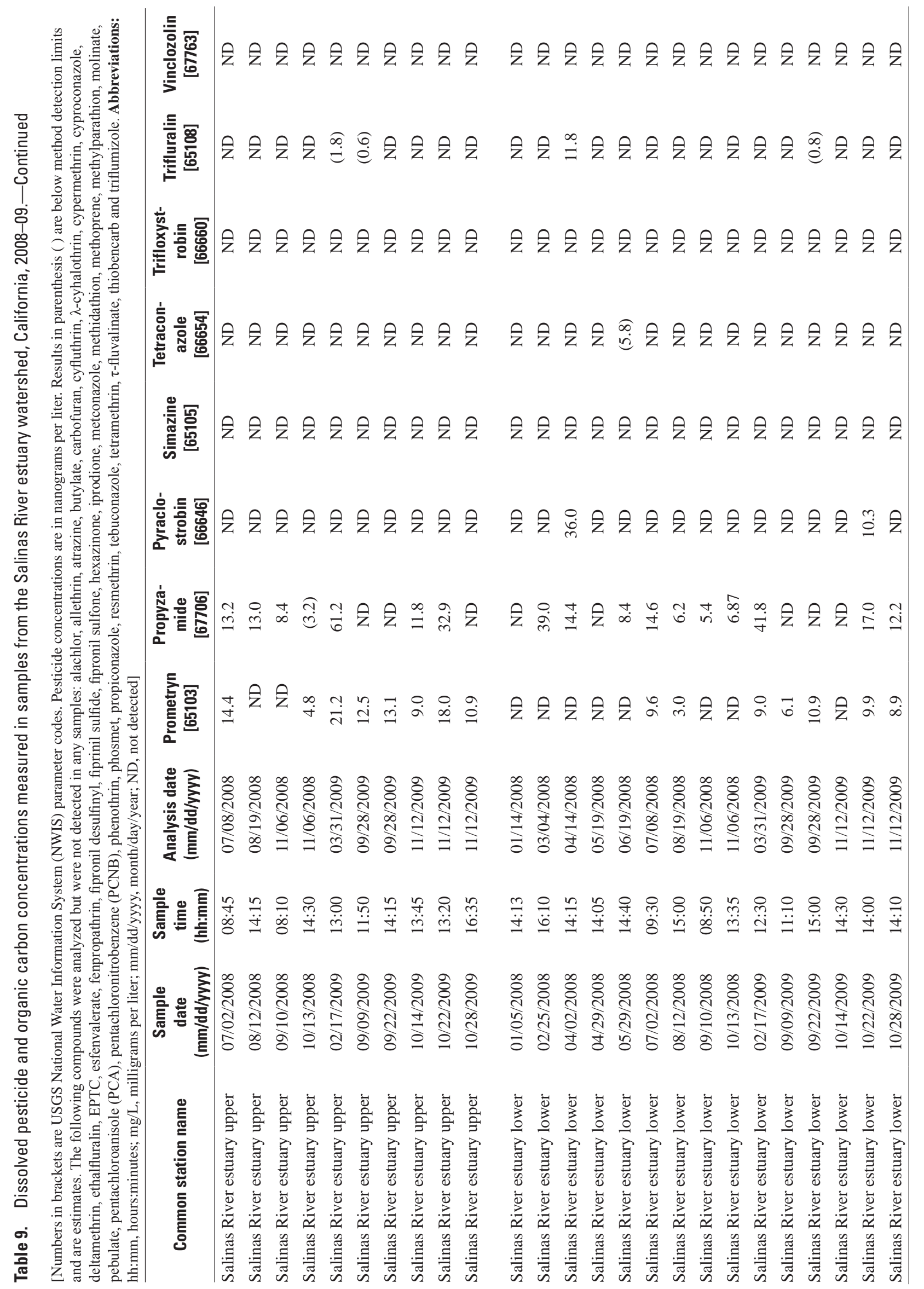




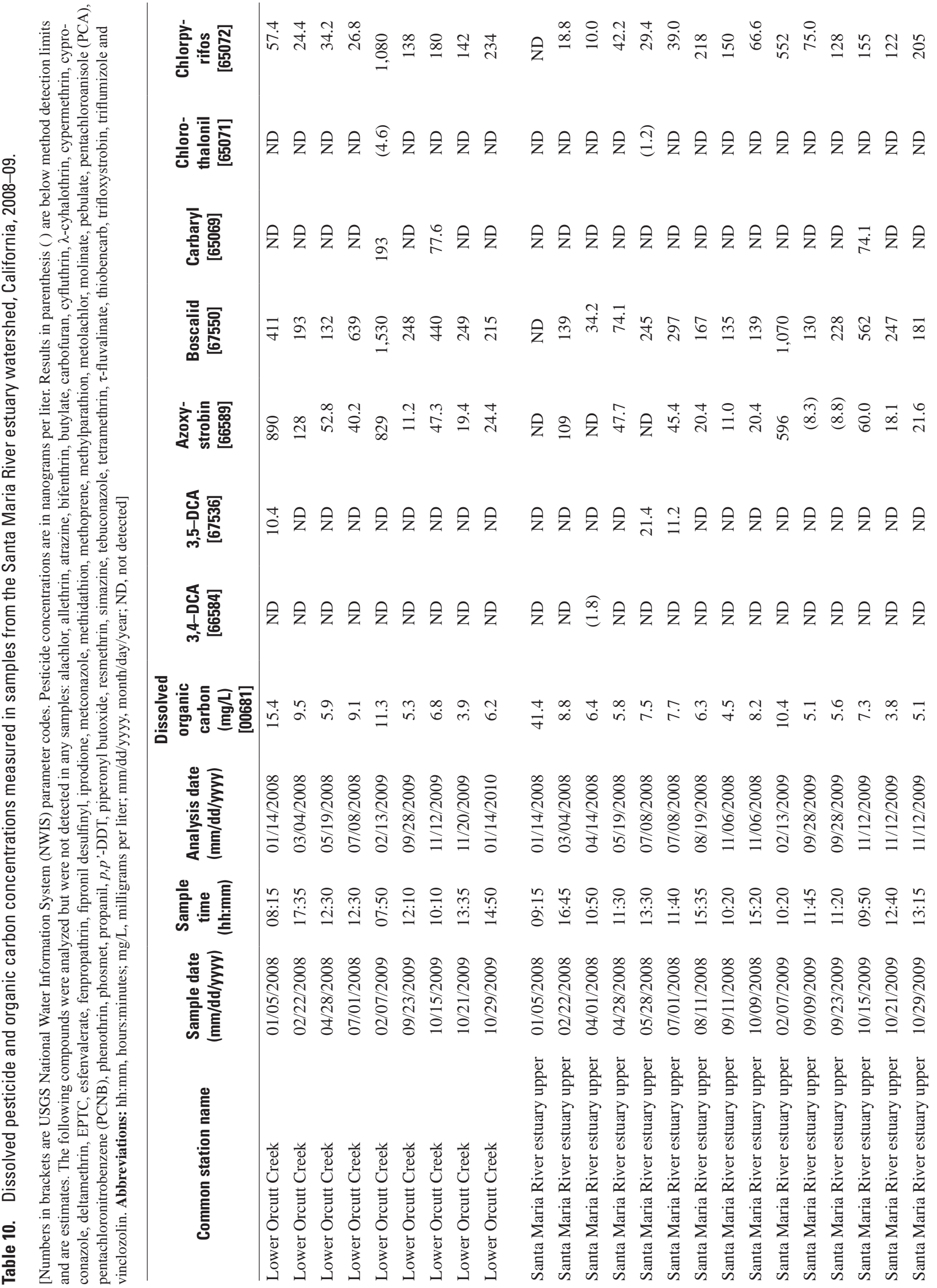




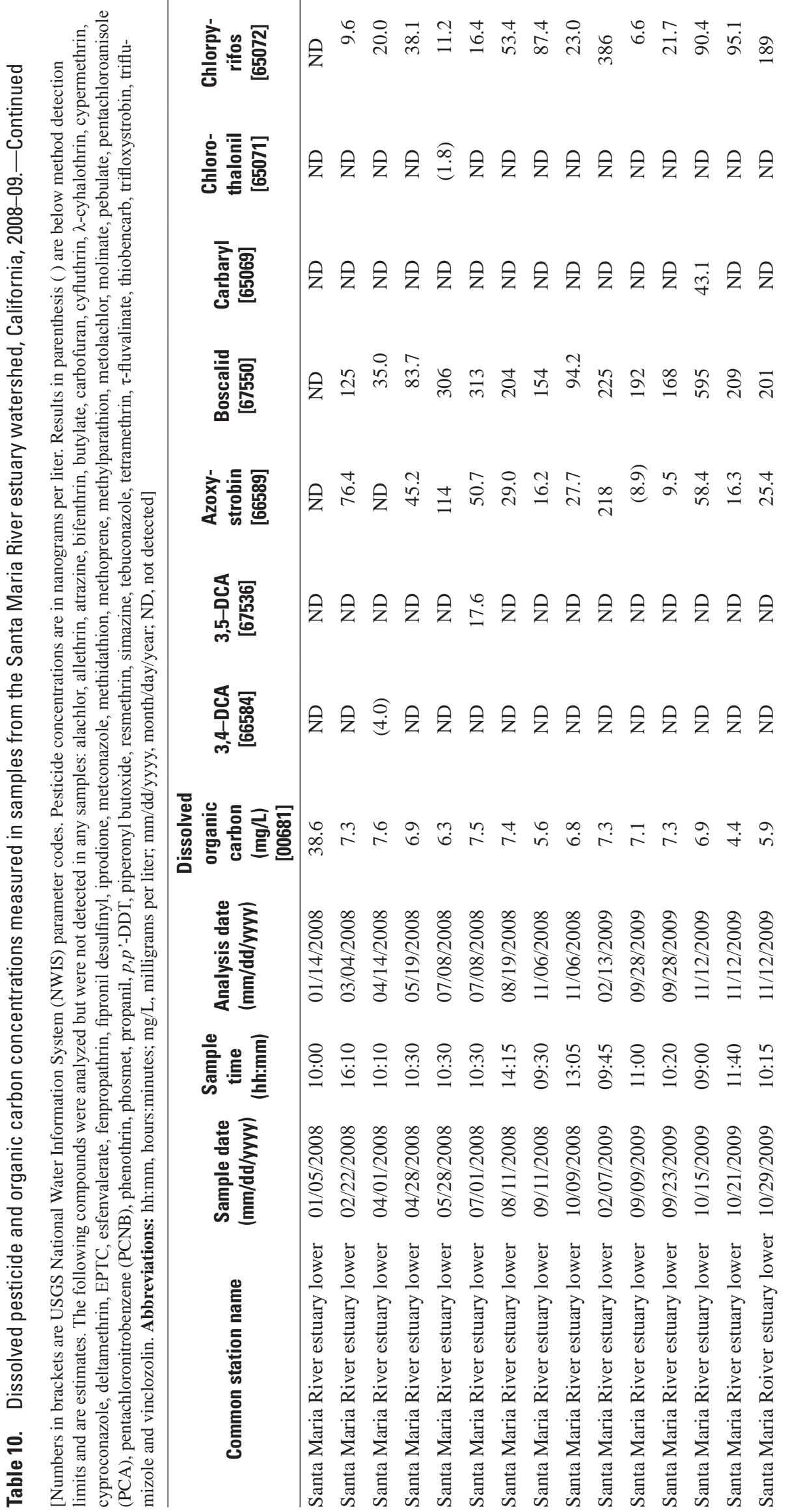




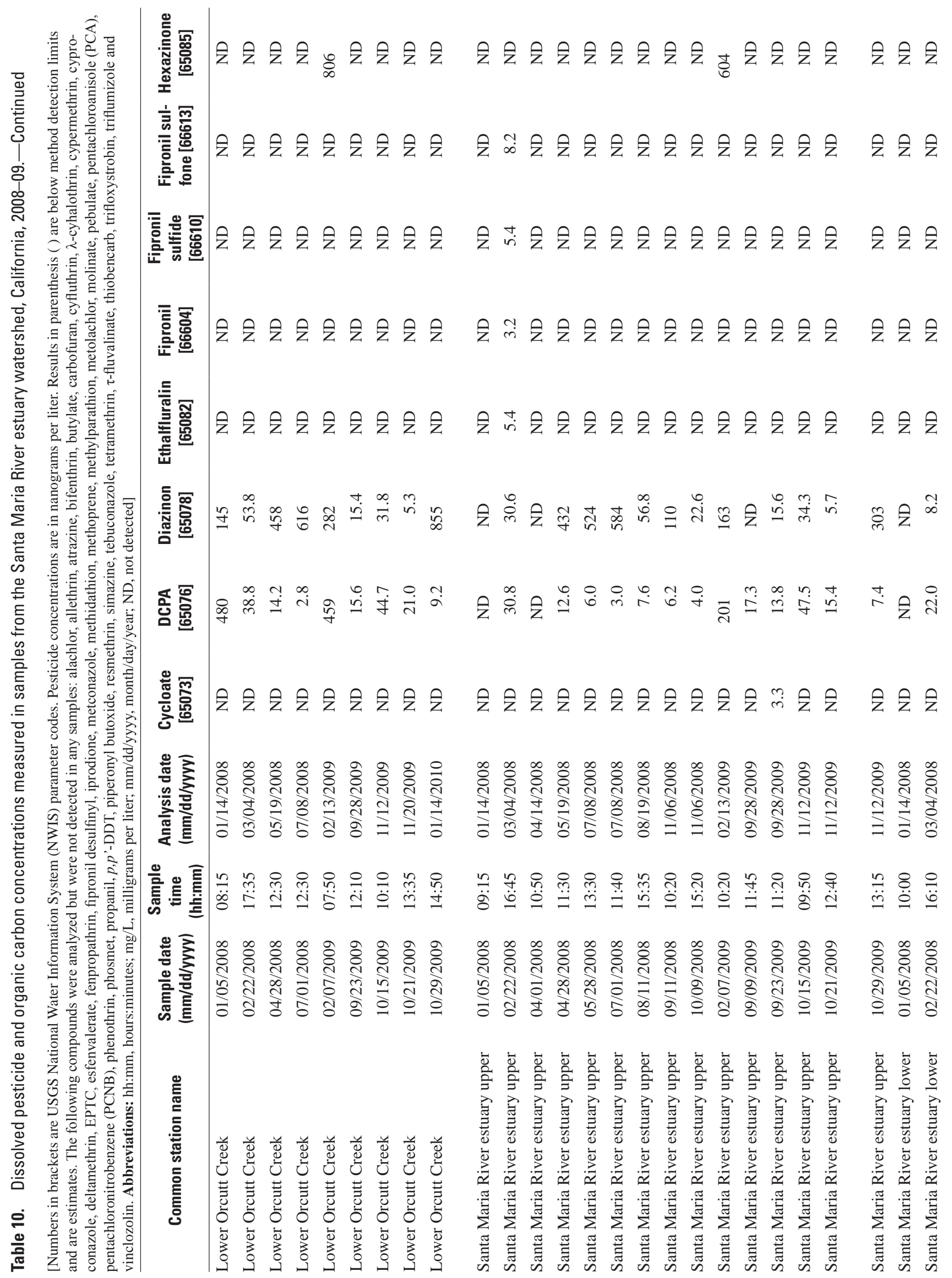




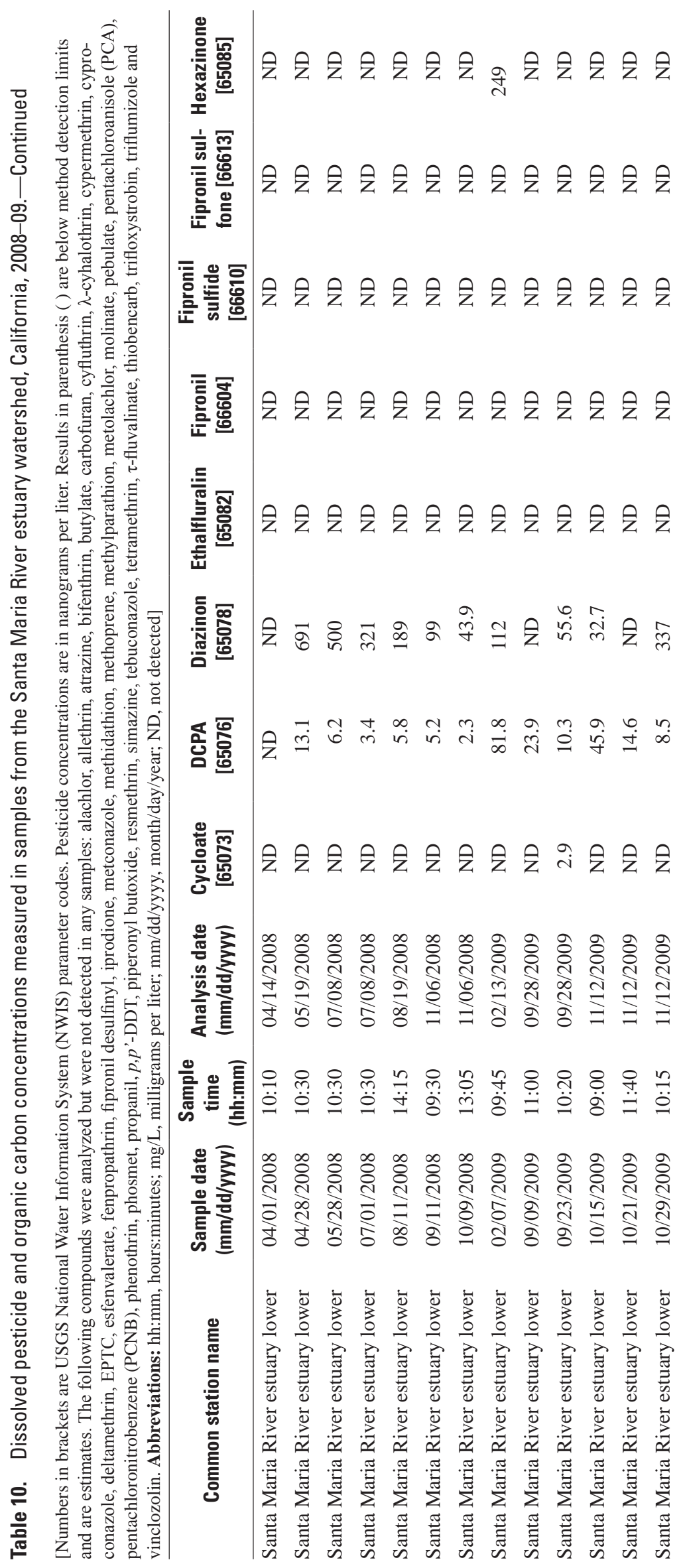




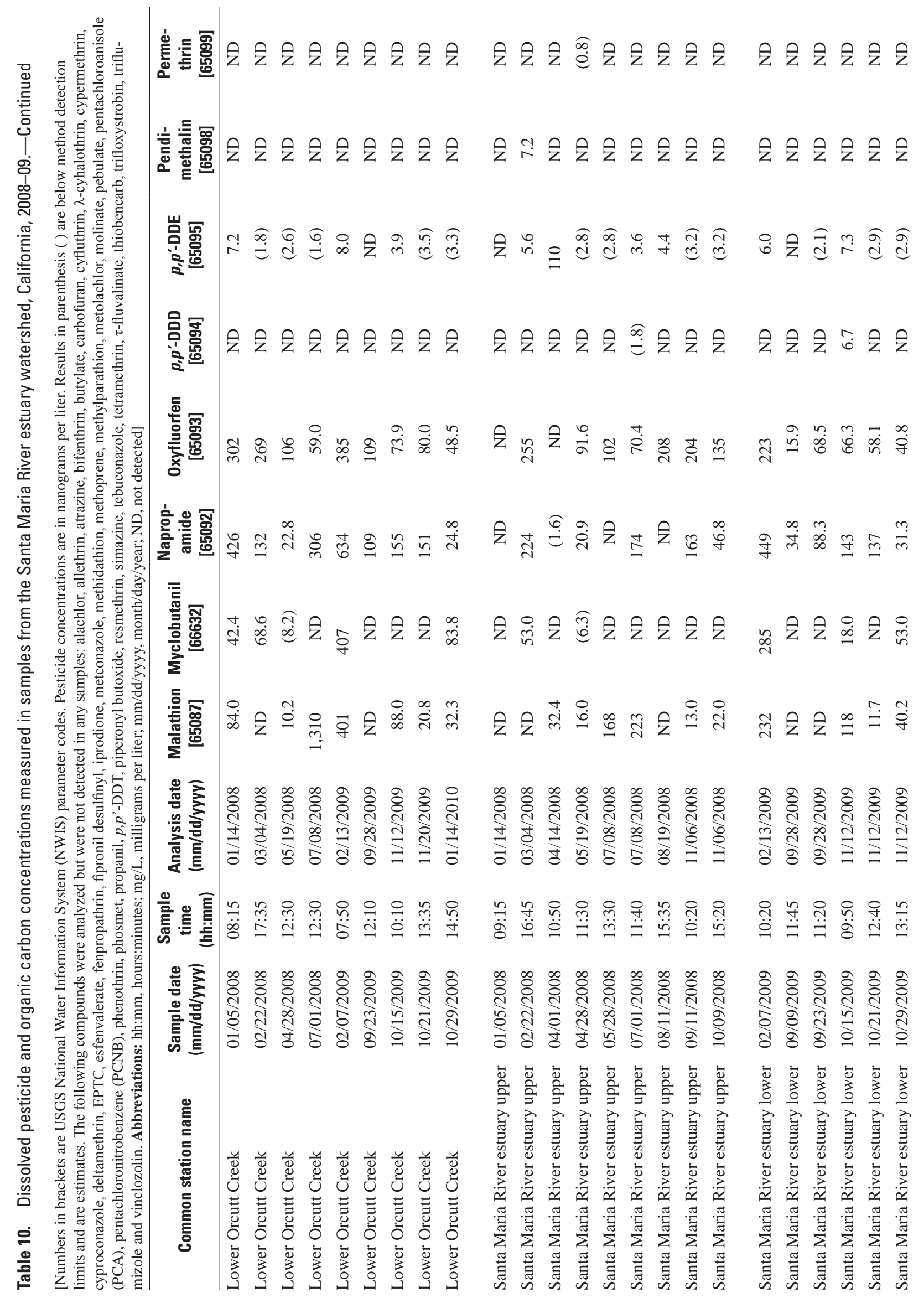




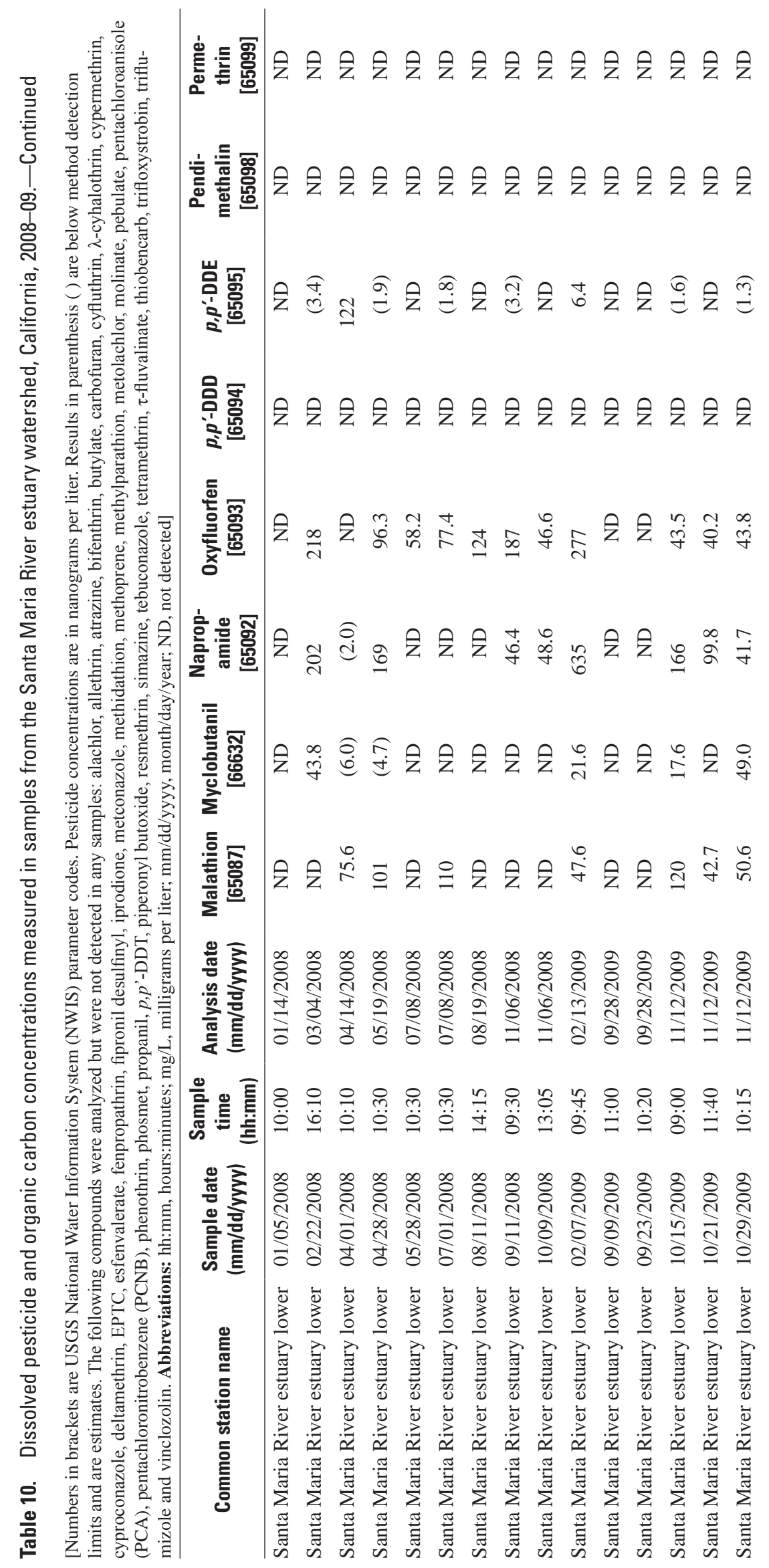




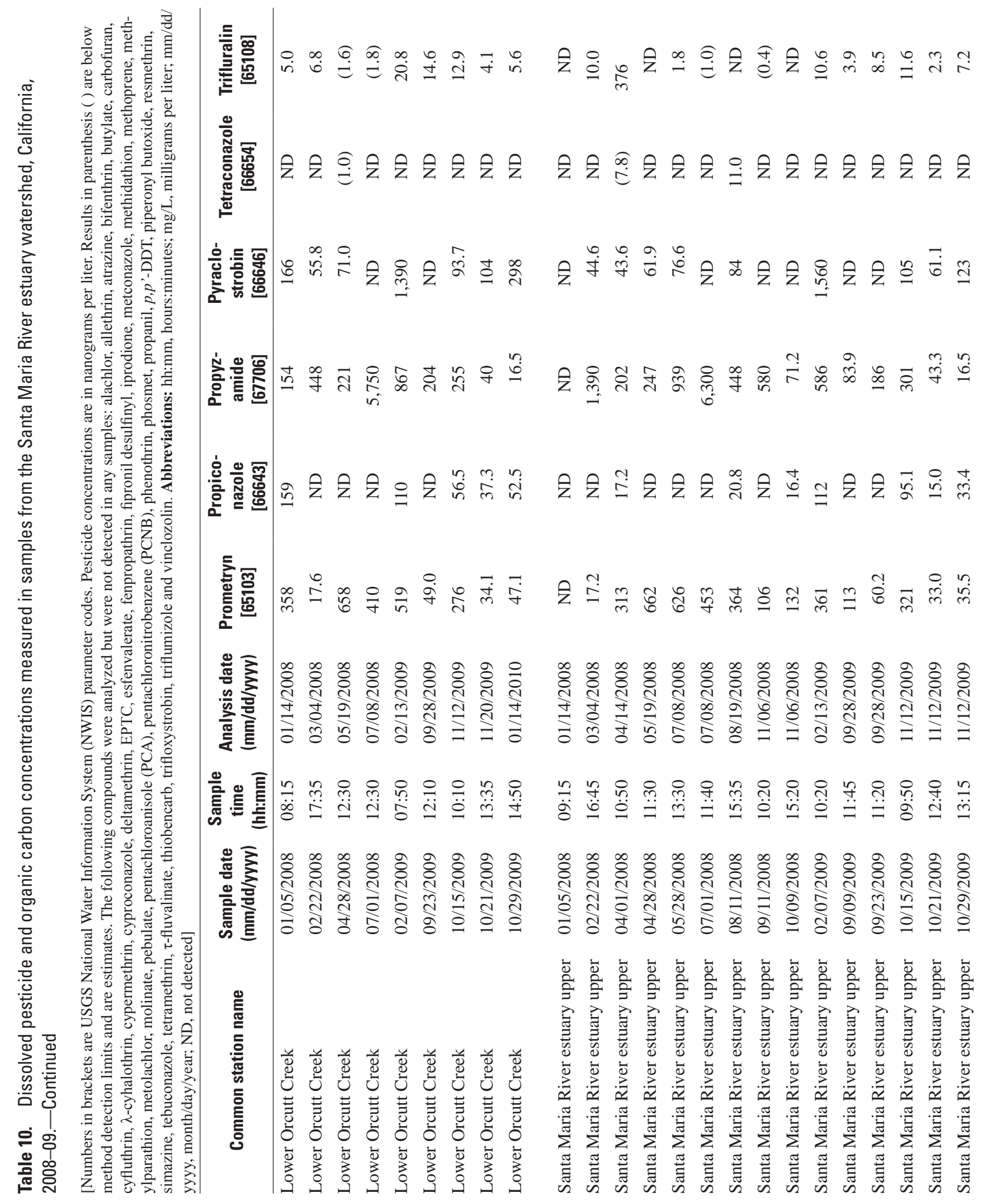




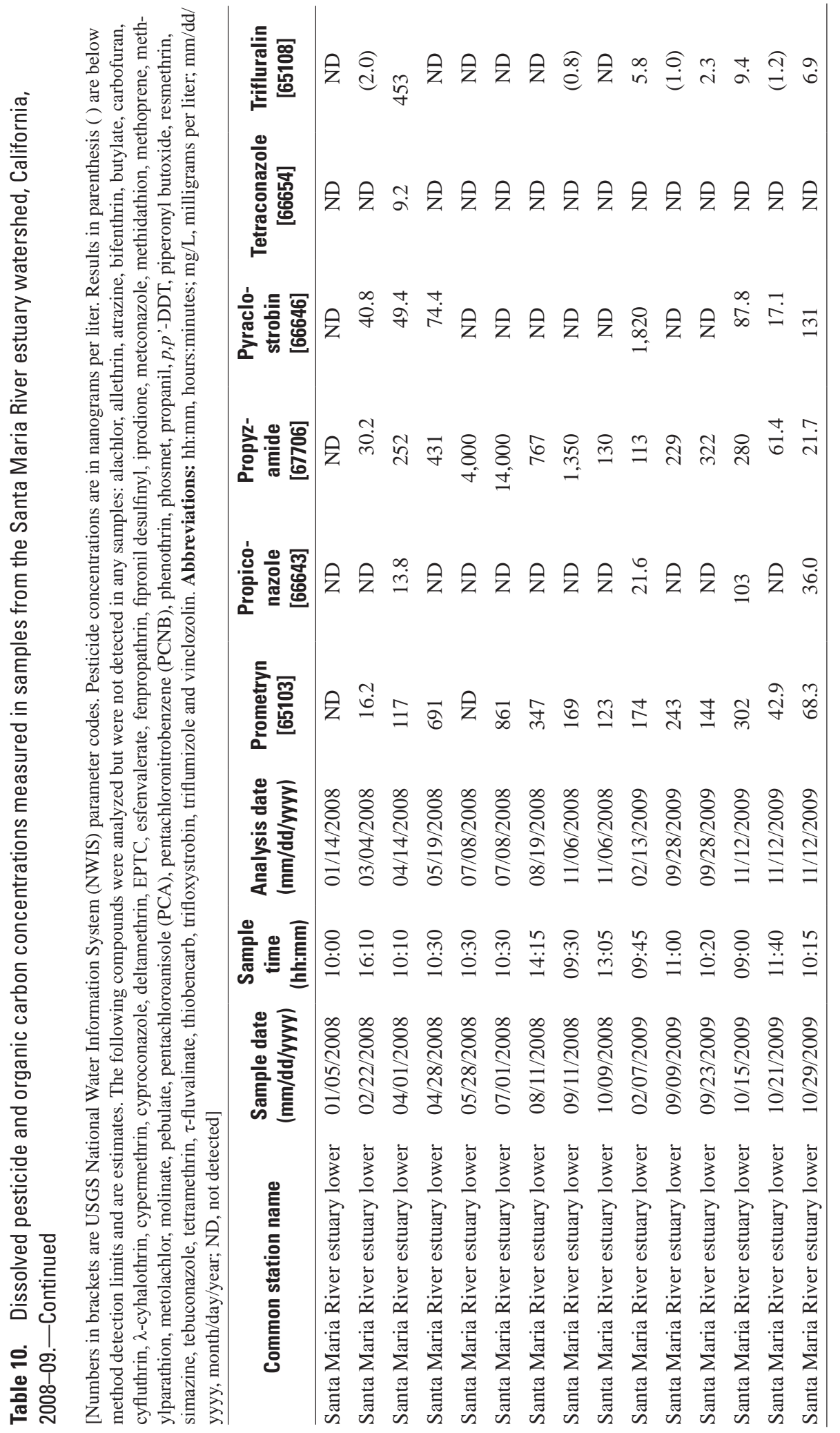




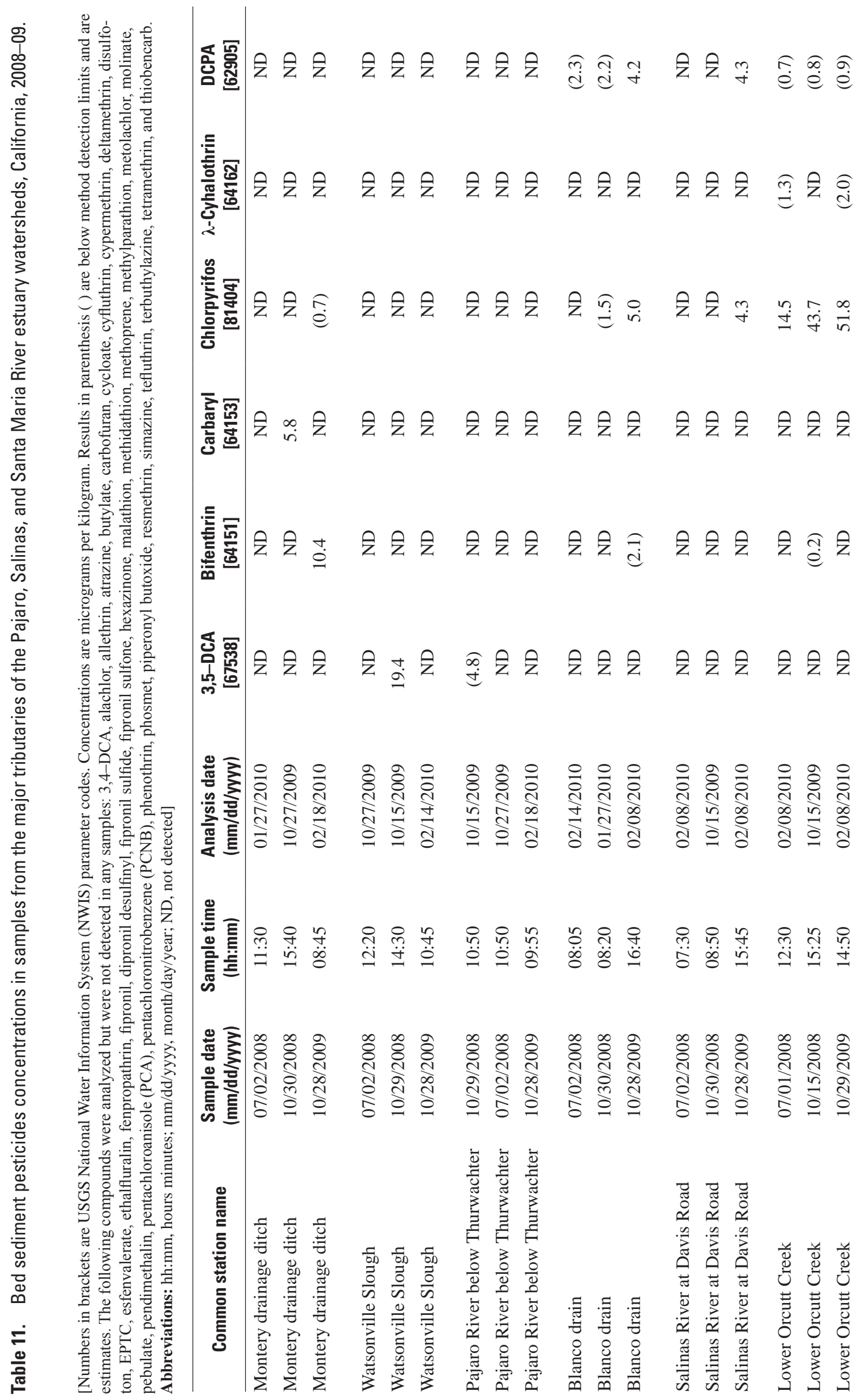




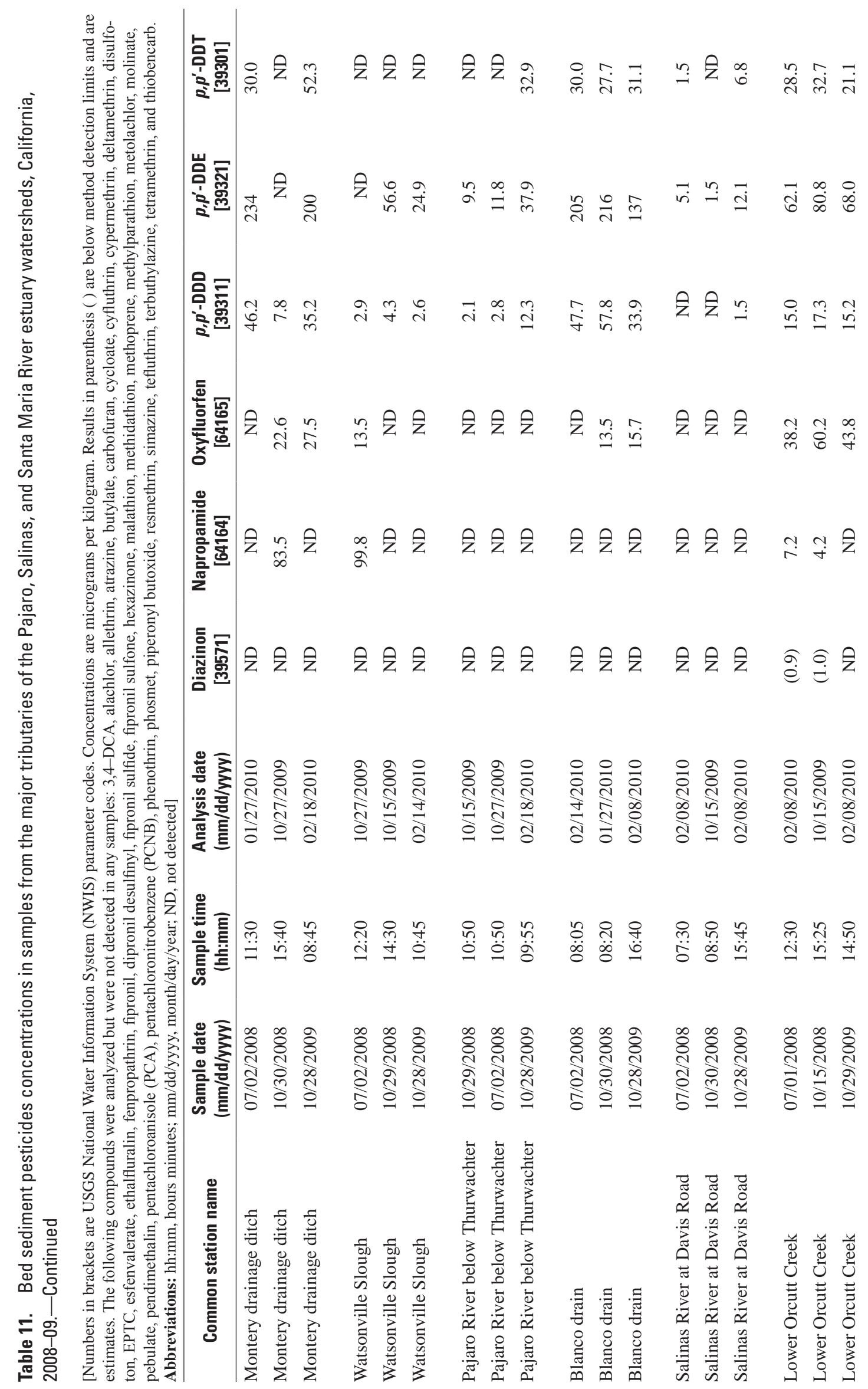




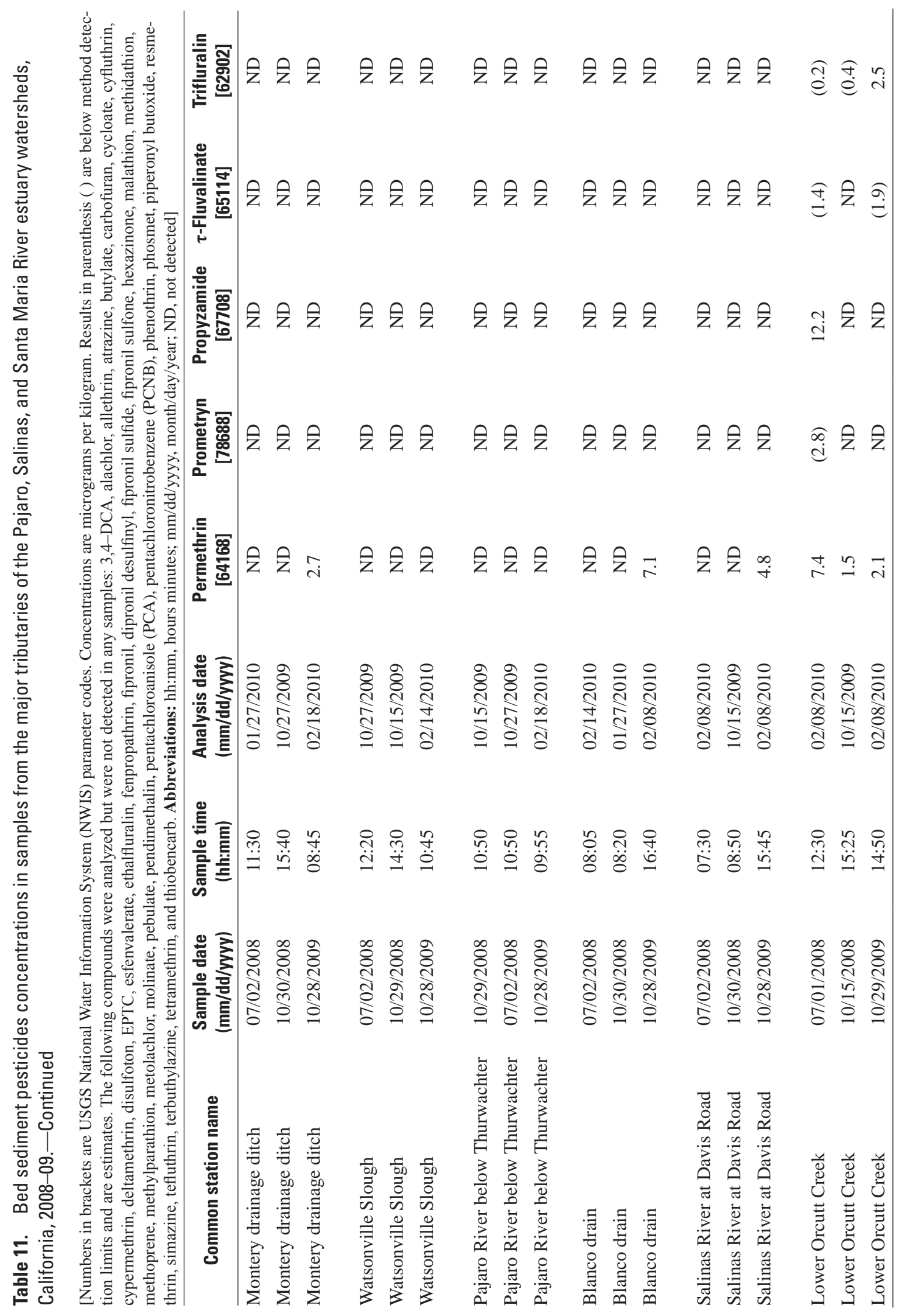




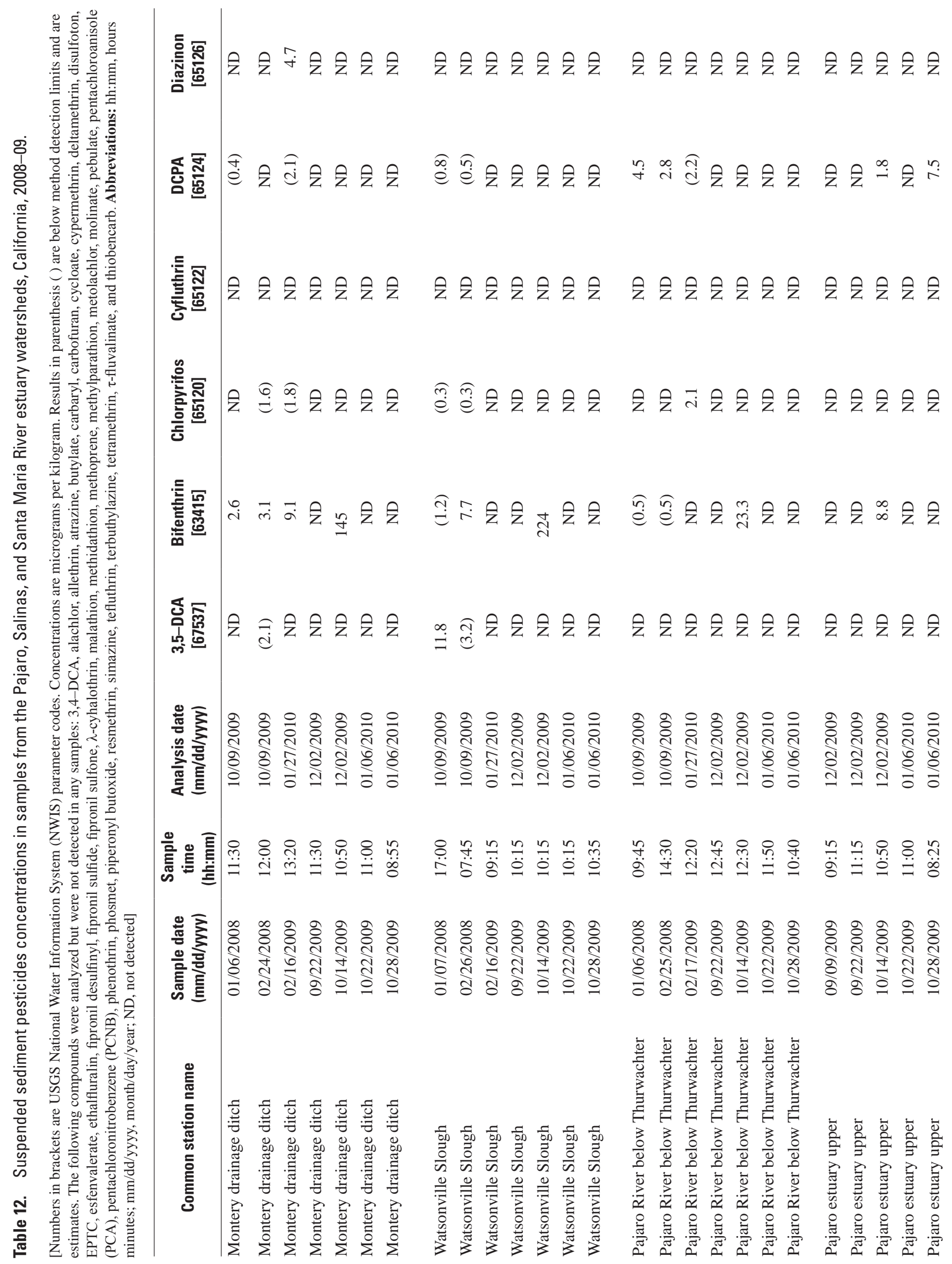




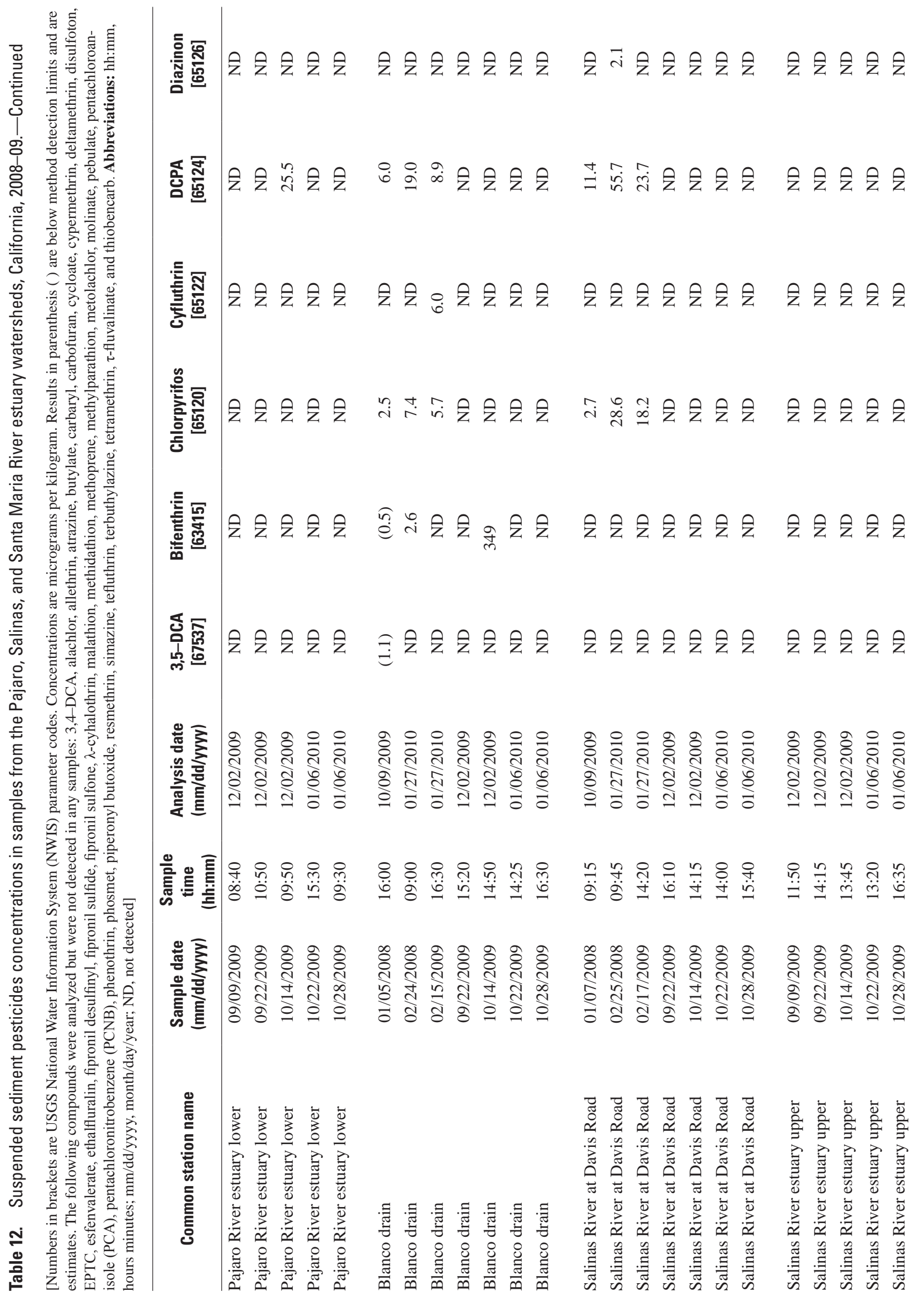




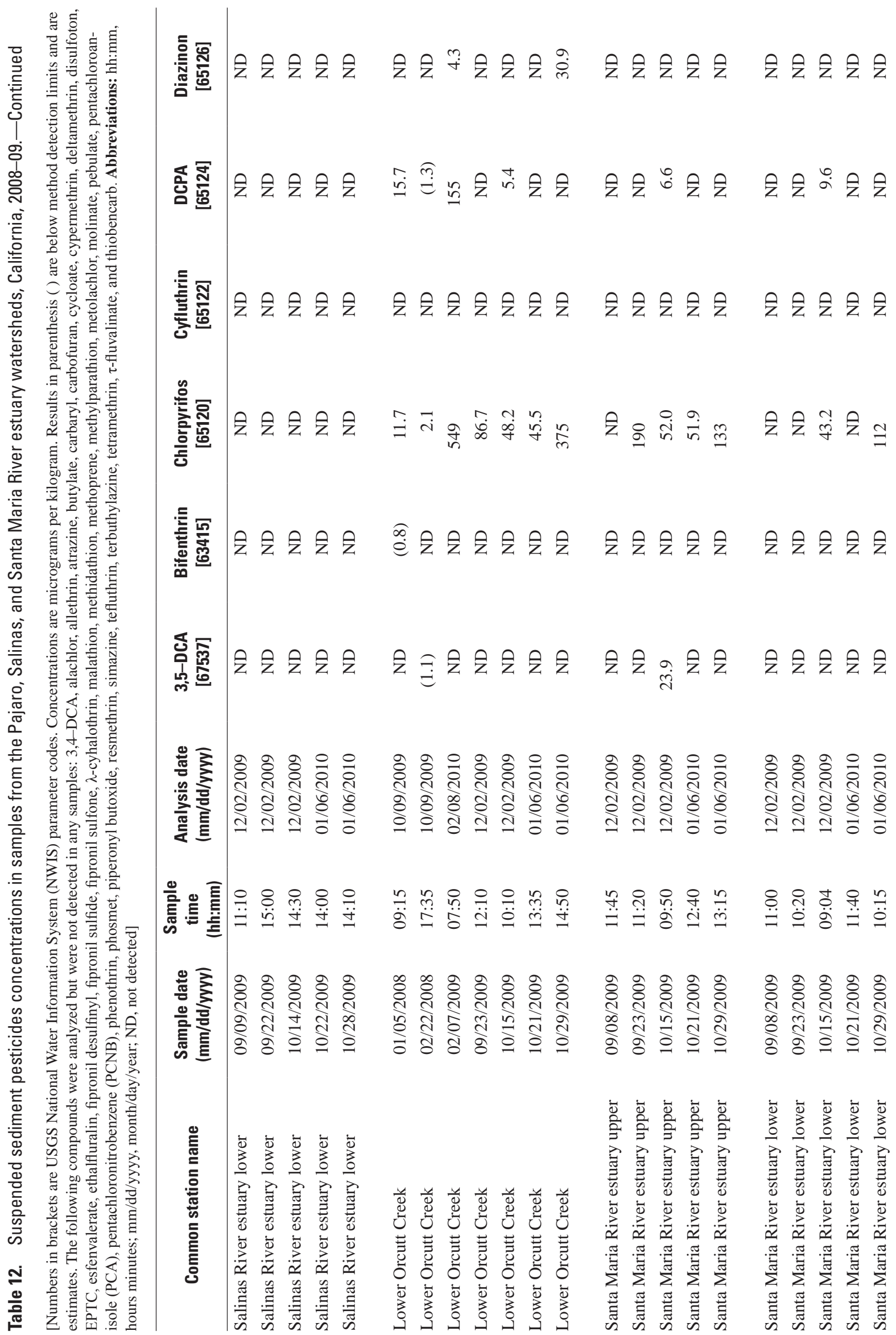




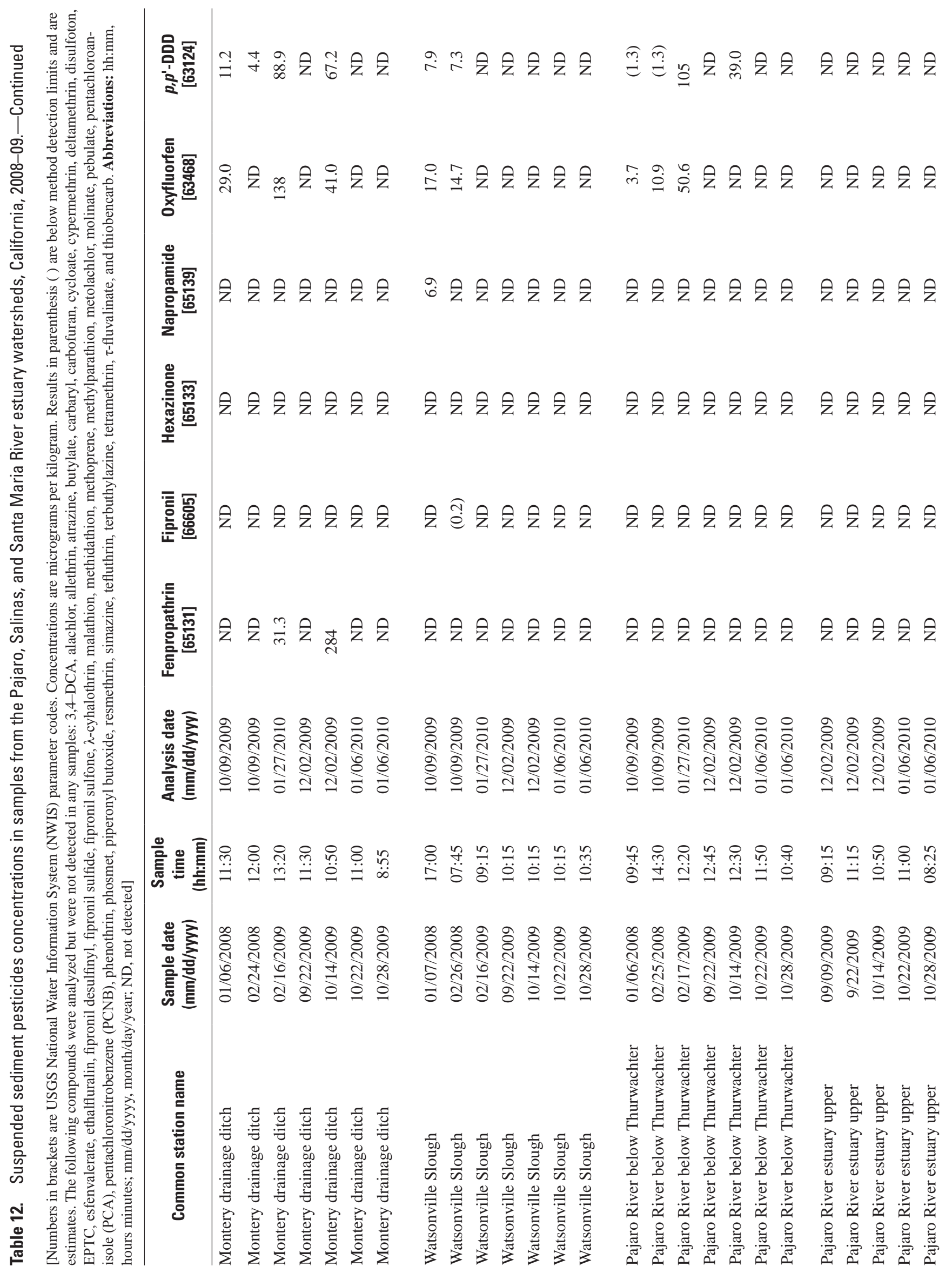




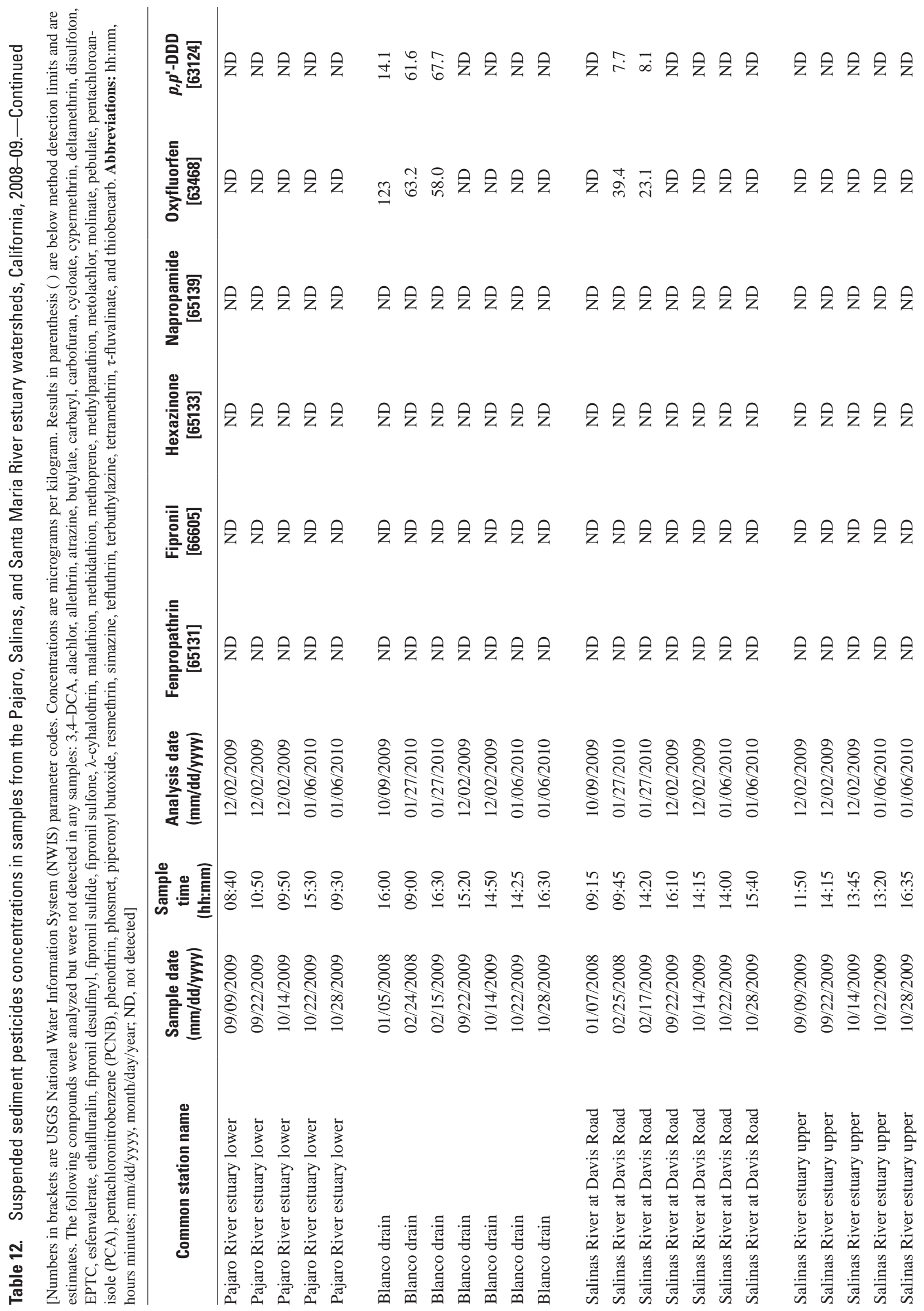




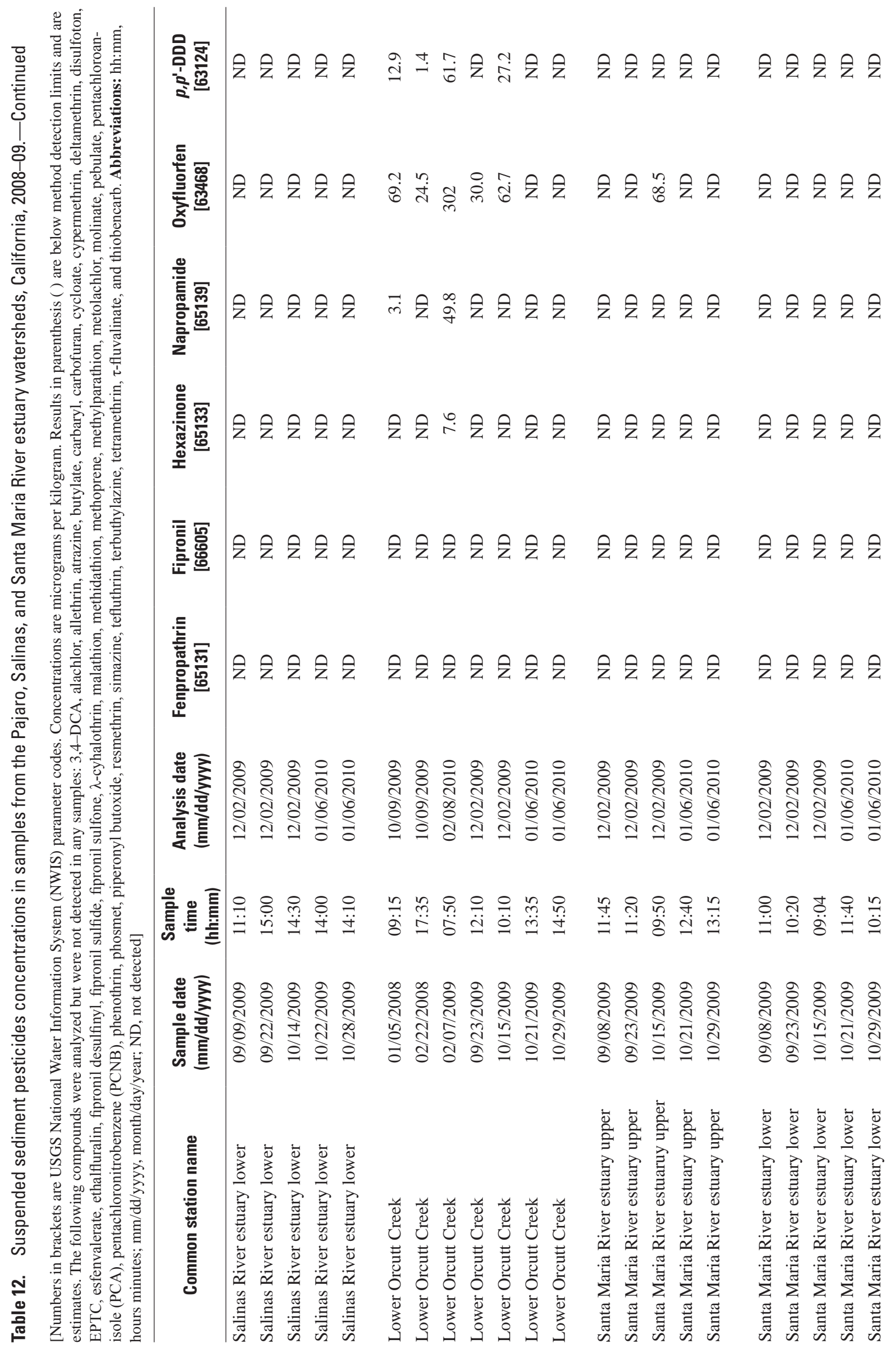




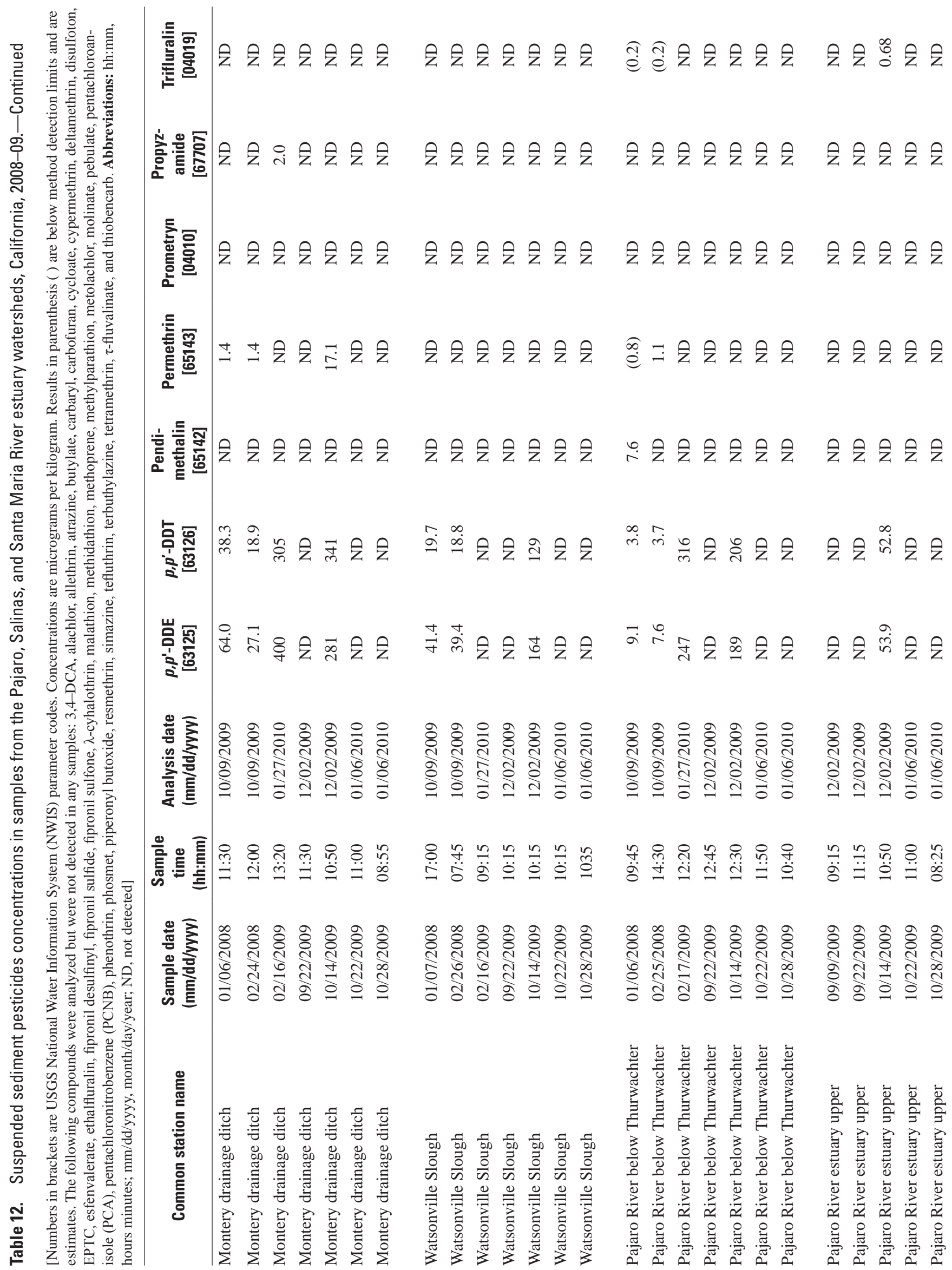




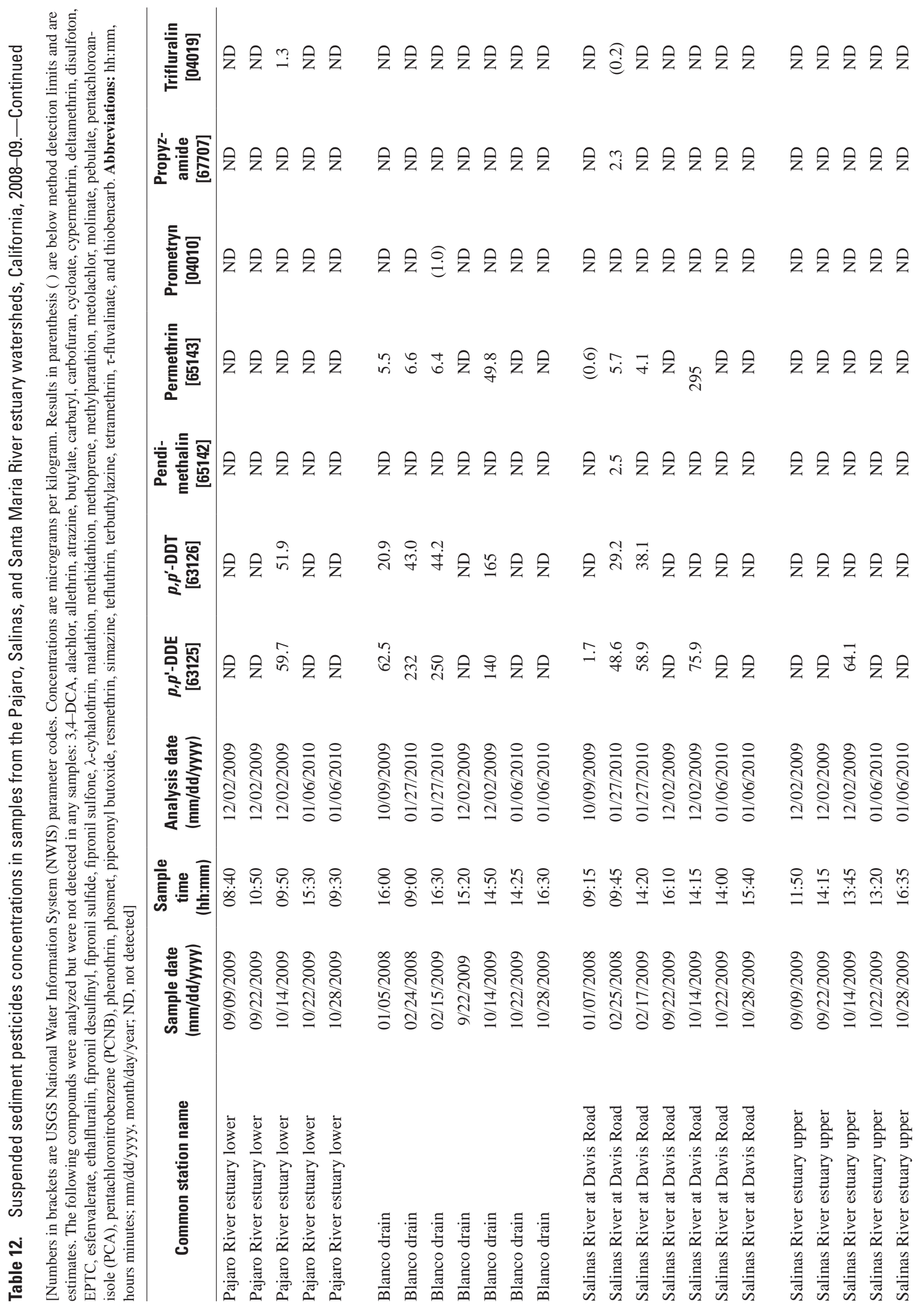




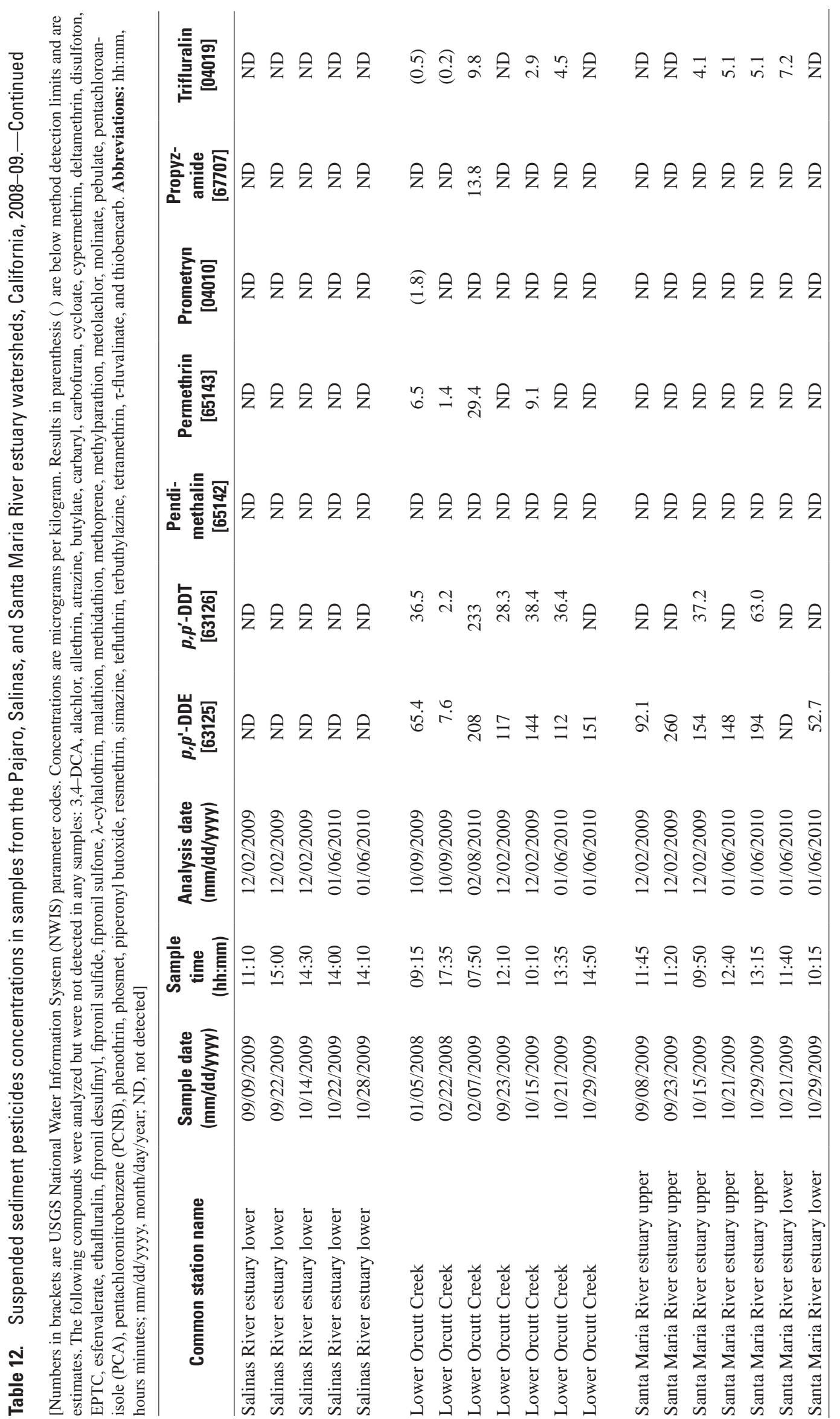


Table 13. Percent organic carbon and nitrogen in suspended and bed sediment samples from the tributary sites in the Pajaro, Salinas, and Santa Maria River estuary watersheds, California, 2008-09.

[Abbreviations: hh:mm; hour:minute; mm/dd/yyyy, month/day/year]

\begin{tabular}{|c|c|c|c|c|c|}
\hline Common station name & $\begin{array}{l}\text { Sample date } \\
\text { (mm/dd/yyyy) }\end{array}$ & $\begin{array}{l}\text { Sample time } \\
\text { (hh:mm) }\end{array}$ & $\begin{array}{l}\text { Sediment } \\
\text { type }\end{array}$ & $\begin{array}{c}\text { Percent organic } \\
\text { carbon }\end{array}$ & $\begin{array}{l}\text { Percent organic } \\
\text { nitrogen }\end{array}$ \\
\hline Monterey drainage ditch & 01/06/2008 & 11:30 & Suspended & 3.4 & 0.4 \\
\hline Monterey drainage ditch & 02/24/2008 & 12:00 & Suspended & 2.8 & 0.3 \\
\hline Monterey drainage ditch & 07/02/2008 & 11:30 & Bed & 3.0 & 0.3 \\
\hline Monterey drainage ditch & 10/30/2008 & $15: 40$ & Bed & 1.7 & 0.2 \\
\hline Monterey drainage ditch & 02/16/2009 & 13:20 & Suspended & 2.9 & 0.3 \\
\hline Monterey drainage ditch & $10 / 28 / 2009$ & 08:45 & Bed & 2.4 & 0.2 \\
\hline Watsonville Slough & 01/07/2008 & $17: 00$ & Suspended & 3.9 & 0.5 \\
\hline Watsonville Slough & 02/26/2008 & 07:45 & Suspended & 4.0 & 0.5 \\
\hline Watsonville Slough & $07 / 02 / 2008$ & $12: 20$ & Bed & 6.8 & 0.5 \\
\hline Watsonville Slough & $10 / 29 / 2008$ & $14: 30$ & Bed & 2.7 & 0.3 \\
\hline Watsonville Slough & 02/16/2009 & 09:15 & Suspended & 4.2 & 0.5 \\
\hline Watsonville Slough & 10/28/2009 & 10:45 & Bed & 4.7 & 0.5 \\
\hline Pajaro River below Thurwachter & 01/06/2008 & 09:45 & Suspended & 2.9 & 0.4 \\
\hline Pajaro River below Thurwachter & $02 / 25 / 2008$ & 14:30 & Suspended & 3.4 & 0.4 \\
\hline Pajaro River below Thurwachter & 07/02/2008 & 10:50 & Bed & 1.5 & 0.1 \\
\hline Pajaro River below Thurwachter & $10 / 29 / 2008$ & 10:50 & Bed & 0.8 & 0.1 \\
\hline Pajaro River below Thurwachter & 02/17/2009 & $12: 20$ & Suspended & 3.8 & 0.4 \\
\hline Pajaro River below Thurwachter & $10 / 28 / 2009$ & 09:55 & Bed & 5.1 & 0.3 \\
\hline Blanco drain & $01 / 05 / 2008$ & 16:00 & Suspended & 3.7 & 0.5 \\
\hline Blanco drain & $02 / 24 / 2008$ & 09:00 & Suspended & 3.6 & 0.4 \\
\hline Blanco drain & 07/02/2008 & 08:05 & Bed & 2.8 & 0.3 \\
\hline Blanco drain & 10/30/2008 & 08:20 & Bed & 3.2 & 0.4 \\
\hline Blanco drain & 02/15/2009 & $16: 30$ & Suspended & 3.4 & 0.4 \\
\hline Blanco drain & $10 / 28 / 2009$ & 16:40 & Bed & 3.9 & 0.3 \\
\hline Salinas River at Davis Road & 01/07/2008 & 09:15 & Suspended & 1.9 & 0.2 \\
\hline Salinas River at Davis Road & 02/25/2008 & 09:45 & Suspended & 2.1 & 0.2 \\
\hline Salinas River at Davis Road & 07/02/2008 & 07:30 & Bed & 2.3 & 0.2 \\
\hline Salinas River at Davis Road & 10/30/2008 & 08:50 & Bed & 1.4 & 0.2 \\
\hline Salinas River at Davis Road & 02/17/2009 & $14: 20$ & Suspended & 2.4 & 0.2 \\
\hline Salinas River at Davis Road & 10/28/2009 & $15: 45$ & Bed & 4.6 & 0.0 \\
\hline Lower Orcutt Creek & 01/05/2008 & 09:15 & Suspended & 1.2 & 0.1 \\
\hline Lower Orcutt Creek & 02/22/2008 & $17: 35$ & Suspended & 3.6 & 0.4 \\
\hline Lower Orcutt Creek & 07/01/2008 & $12: 30$ & Bed & 1.5 & 0.1 \\
\hline Lower Orcutt Creek & $10 / 15 / 2008$ & 15:25 & Bed & 1.3 & 0.1 \\
\hline Lower Orcutt Creek & 02/07/2009 & 07:50 & Suspended & 4.3 & 0.4 \\
\hline Lower Orcutt Creek & 10/29/2009 & 14:50 & Bed & 1.8 & 0.1 \\
\hline
\end{tabular}


Table 14. Discrete (single-point) and cross-sectional measurements for water-quality parameters at sampling sites in the Pajaro, Salinas, and Santa Maria River estuary watersheds, California, 2008-09.

[Numbers in brackets are U.S. Geological Survey National Water Information System (NWIS) parameter codes. Abbreviations: hh:mm, hour:minute; mg/L, milligram per liter; mm/dd/yyyy, month/day/year; NA, not analyzed; FNU, Formazin Nephelometric Unit; ${ }^{\circ} \mathrm{C}$, degree Celsius; $\mu \mathrm{S} / \mathrm{cm}$, microsiemens per centimeter]

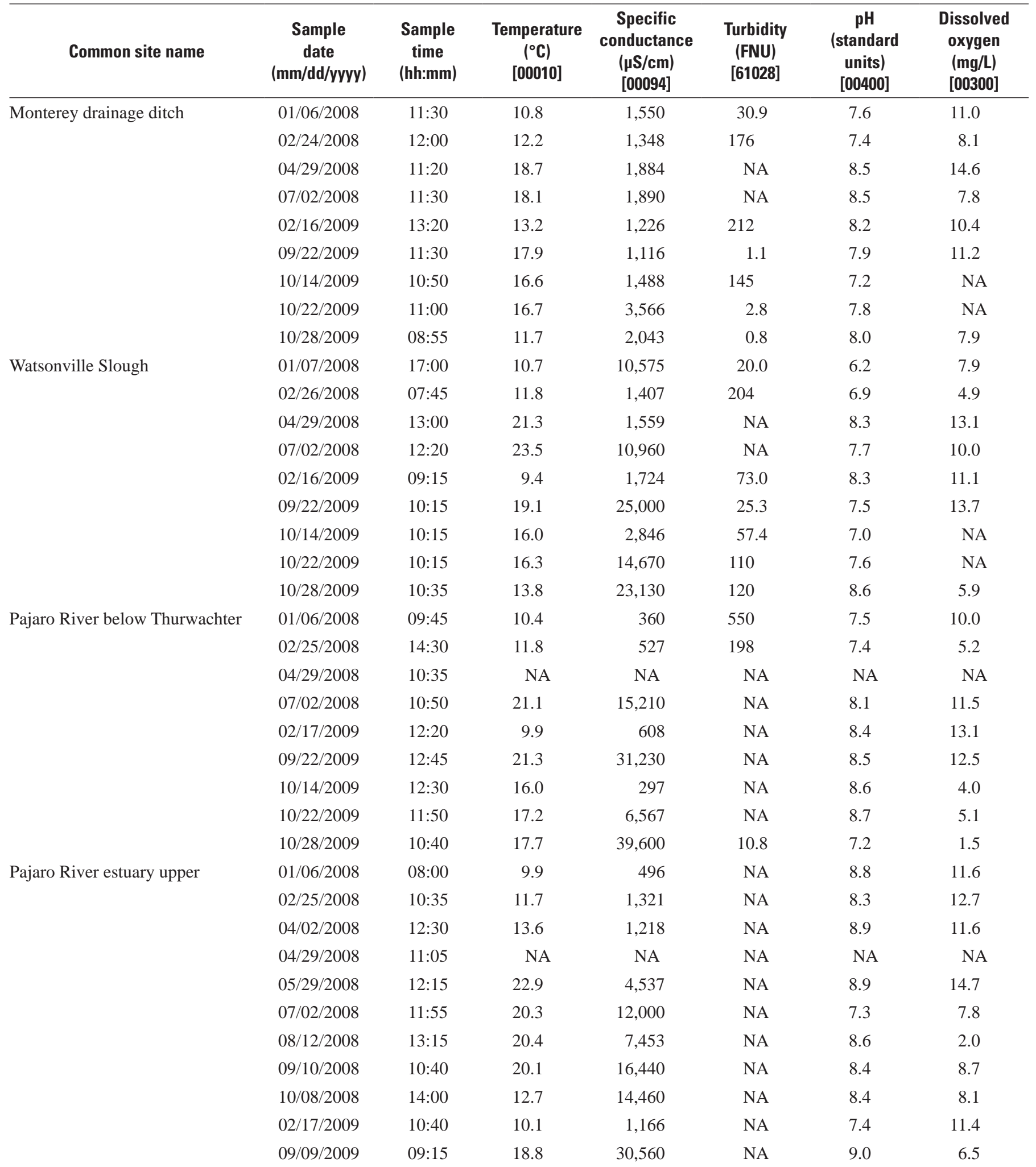


Table 14. Discrete (single-point) and cross-sectional measurements for water-quality parameters at sampling sites in the Pajaro, Salinas, and Santa Maria River estuary watersheds, California, 2008-09._Continued

[Numbers in brackets are U.S. Geological Survey National Water Information System (NWIS) parameter codes. Abbreviations: hh:mm, hour:minute; mg/L, milligram per liter; mm/dd/yyyy, month/day/year; NA, not analyzed; FNU, Formazin Nephelometric Unit; ${ }^{\circ} \mathrm{C}$, degree Celsius; $\mu \mathrm{S} / \mathrm{cm}$, microsiemens per centimeter]

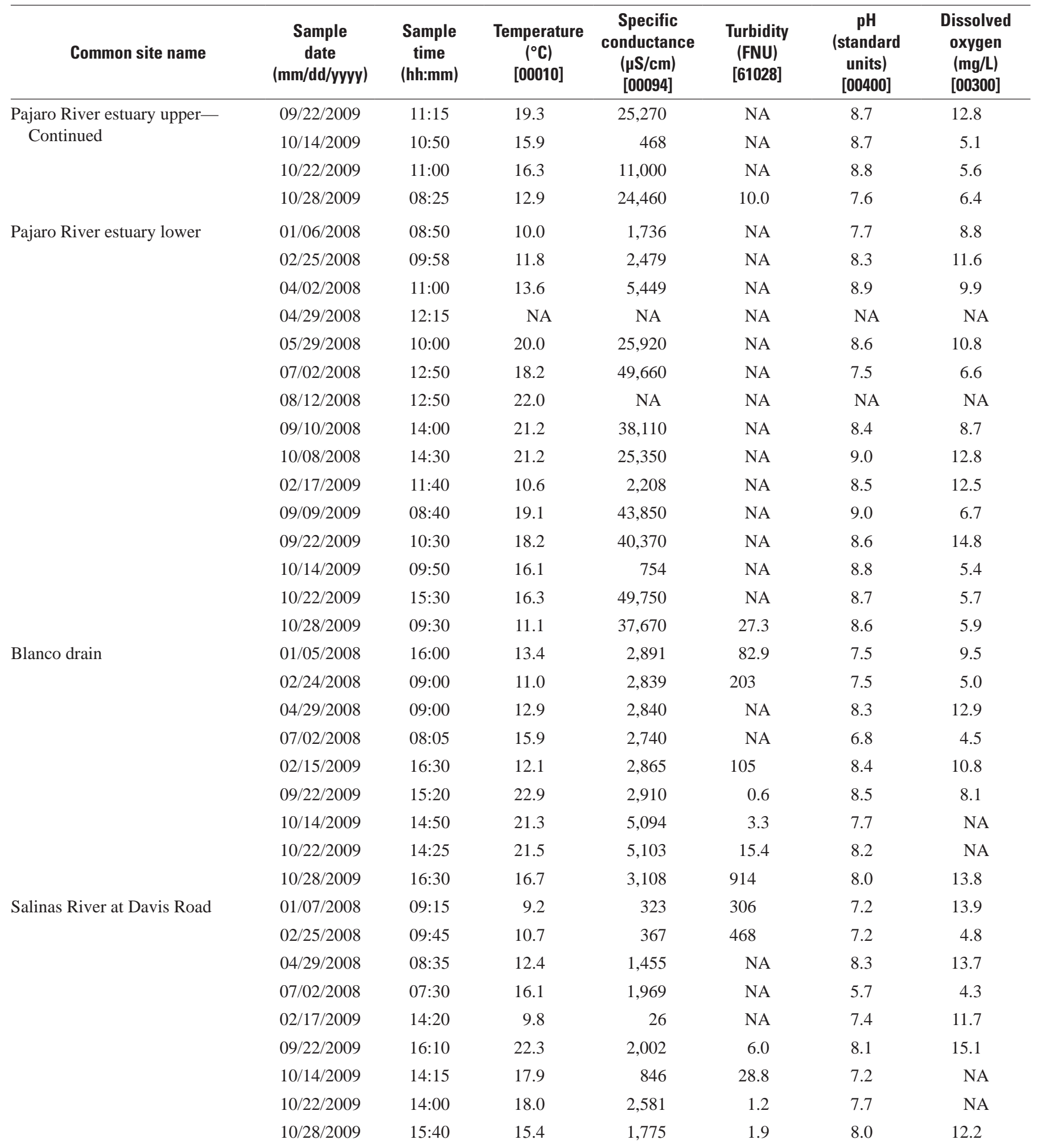


Table 14. Discrete (single-point) and cross-sectional measurements for water-quality parameters at sampling sites in the Pajaro, Salinas, and Santa Maria River estuary watersheds, California, 2008-09.-Continued

[Numbers in brackets are U.S. Geological Survey National Water Information System (NWIS) parameter codes. Abbreviations: hh:mm, hour:minute; mg/L, milligram per liter; mm/dd/yyyy, month/day/year; NA, not analyzed; FNU, Formazin Nephelometric Unit; ${ }^{\circ} \mathrm{C}$, degree Celsius; $\mu \mathrm{S} / \mathrm{cm}$, microsiemens per centimeter]

\begin{tabular}{|c|c|c|c|c|c|c|c|}
\hline Common site name & $\begin{array}{c}\text { Sample } \\
\text { date } \\
\text { (mm/dd/yyyy) }\end{array}$ & $\begin{array}{c}\text { Sample } \\
\text { time } \\
\text { (hh:mm) }\end{array}$ & $\begin{array}{c}\text { Temperature } \\
\left({ }^{\circ} \mathrm{C}\right) \\
{[00010]}\end{array}$ & 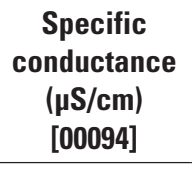 & $\begin{array}{c}\text { Turbidity } \\
\text { (FNU) } \\
\text { [61028] }\end{array}$ & $\begin{array}{c}\text { pH } \\
\text { (standard } \\
\text { units) } \\
{[00400]} \\
\end{array}$ & $\begin{array}{c}\text { Dissolved } \\
\text { oxygen } \\
\text { (mg/L) } \\
{[00300]}\end{array}$ \\
\hline \multirow[t]{11}{*}{ Salinas River estuary upper } & 01/05/2008 & $13: 28$ & 11.0 & 6,621 & NA & 8.2 & 8.3 \\
\hline & 02/25/2008 & 08:15 & 11.4 & 6,006 & NA & 8.3 & 12.1 \\
\hline & 04/02/2008 & $13: 45$ & 14.2 & 1,140 & NA & 9.1 & 14.9 \\
\hline & 05/29/2008 & $14: 00$ & 22.3 & 21,150 & NA & 8.9 & 14.9 \\
\hline & 07/02/2008 & 08:45 & 18.1 & 6,110 & NA & 7.7 & 6.2 \\
\hline & 08/12/2008 & $14: 15$ & 22.1 & 20 & NA & 6.3 & 9.9 \\
\hline & 09/10/2008 & 08:10 & 17.9 & 3,261 & NA & 8.5 & 7.9 \\
\hline & 09/22/2009 & $14: 15$ & 21.1 & 10,560 & NA & 9.0 & 11.8 \\
\hline & $10 / 14 / 2009$ & $13: 45$ & 20.1 & 7,036 & NA & 8.3 & 5.6 \\
\hline & $10 / 22 / 2009$ & $13: 20$ & 19.9 & 6,820 & NA & 9.1 & 8.9 \\
\hline & 10/28/2009 & $16: 35$ & 15.8 & 10,750 & NA & 9.4 & 9.0 \\
\hline \multirow[t]{9}{*}{ Salinas River estuary lower } & 01/05/2008 & $14: 13$ & 11.4 & 38,180 & NA & 7.9 & 11.1 \\
\hline & 02/25/2008 & $16: 10$ & 11.3 & 8,799 & NA & 7.9 & 11.2 \\
\hline & 04/02/2008 & $14: 15$ & 13.5 & 13,770 & NA & 8.5 & 10.5 \\
\hline & 04/29/2008 & $14: 05$ & 16.9 & 48,020 & NA & 8.3 & 9.6 \\
\hline & 05/29/2008 & $14: 40$ & 20.8 & 38,530 & NA & 8.7 & 9.2 \\
\hline & 09/22/2009 & $15: 00$ & 21.3 & 12,840 & NA & 9.0 & 10.6 \\
\hline & $10 / 14 / 2009$ & $14: 30$ & 17.7 & 13,780 & NA & 9.1 & 9.1 \\
\hline & $10 / 22 / 2009$ & $14: 00$ & 18.5 & 12,430 & NA & 9.4 & 9.3 \\
\hline & 10/28/2009 & $14: 10$ & 14.9 & 13,650 & NA & 9.2 & 8.1 \\
\hline \multirow[t]{9}{*}{ Lower Orcutt Creek } & 01/05/2008 & 08:15 & 11.4 & 2,085 & 870 & 7.2 & 8.9 \\
\hline & 02/22/2008 & $17: 35$ & 14.2 & 1,779 & 420 & 7.2 & 5.9 \\
\hline & 04/28/2008 & $12: 30$ & 21.4 & 2,534 & NA & 8.1 & 10.0 \\
\hline & 07/01/2008 & $12: 30$ & NA & NA & NA & NA & NA \\
\hline & 02/07/2009 & $07: 50$ & 11.7 & 2,582 & 146 & 8.1 & 9.0 \\
\hline & 09/23/2009 & $12: 10$ & 20.0 & 2,099 & 55.0 & 7.9 & 10.6 \\
\hline & 10/15/2009 & $10: 10$ & 19.0 & 105 & NA & 8.9 & 6.6 \\
\hline & 10/21/2009 & $13: 35$ & 20.9 & 2,671 & NA & 8.8 & 6.1 \\
\hline & $10 / 29 / 2009$ & $14: 50$ & 16.8 & 2,745 & NA & 8.3 & 7.1 \\
\hline
\end{tabular}


Table 14. Discrete (single-point) and cross-sectional measurements for water-quality parameters at sampling sites in the Pajaro, Salinas, and Santa Maria River estuary watersheds, California, 2008-09.-Continued

[Numbers in brackets are U.S. Geological Survey National Water Information System (NWIS) parameter codes. Abbreviations: hh:mm, hour:minute; mg/L, milligram per liter; mm/dd/yyyy, month/day/year; NA, not analyzed; FNU, Formazin Nephelometric Unit; ${ }^{\circ} \mathrm{C}$, degree Celsius; $\mu \mathrm{S} / \mathrm{cm}$, microsiemens per centimeter]

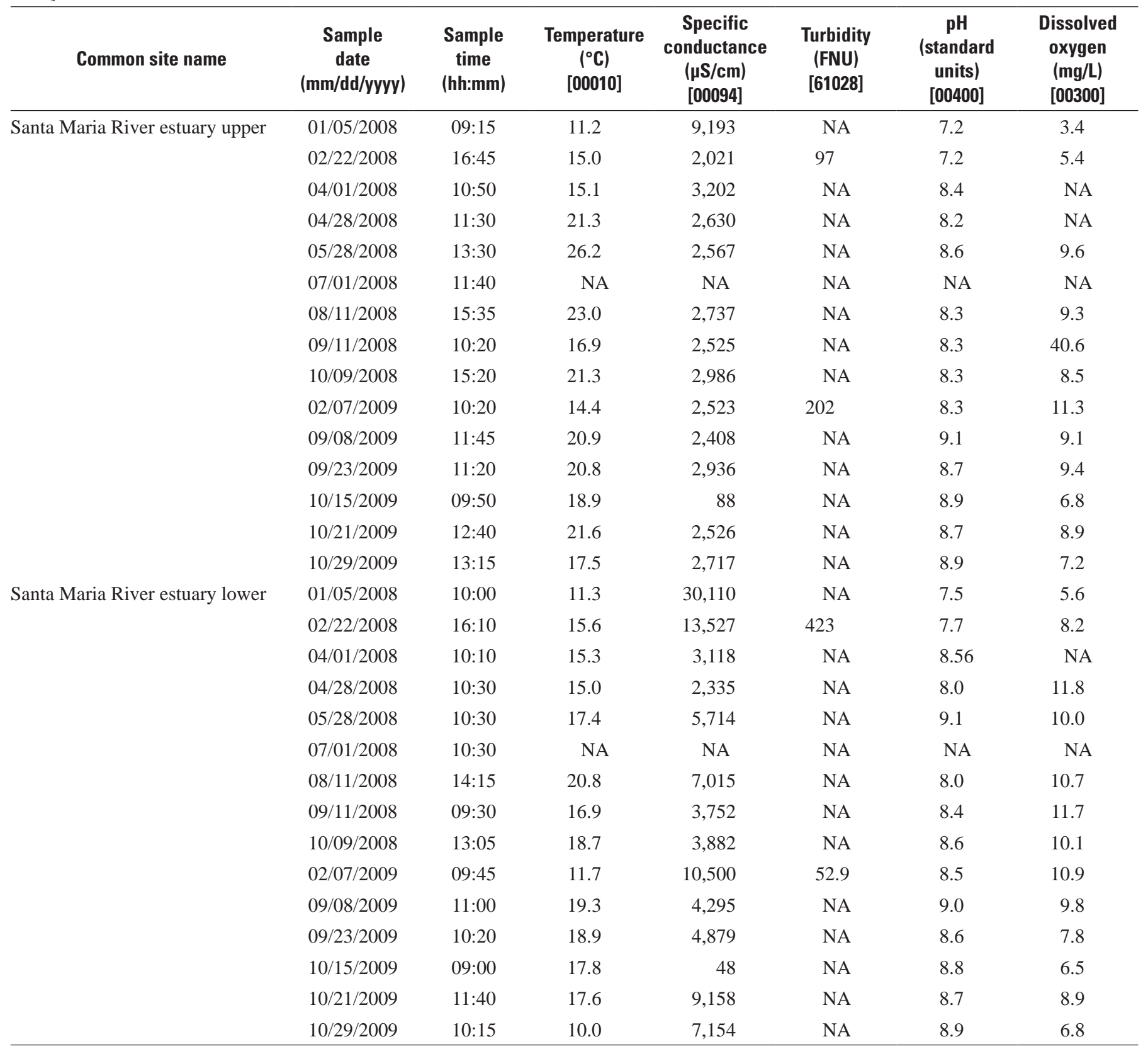




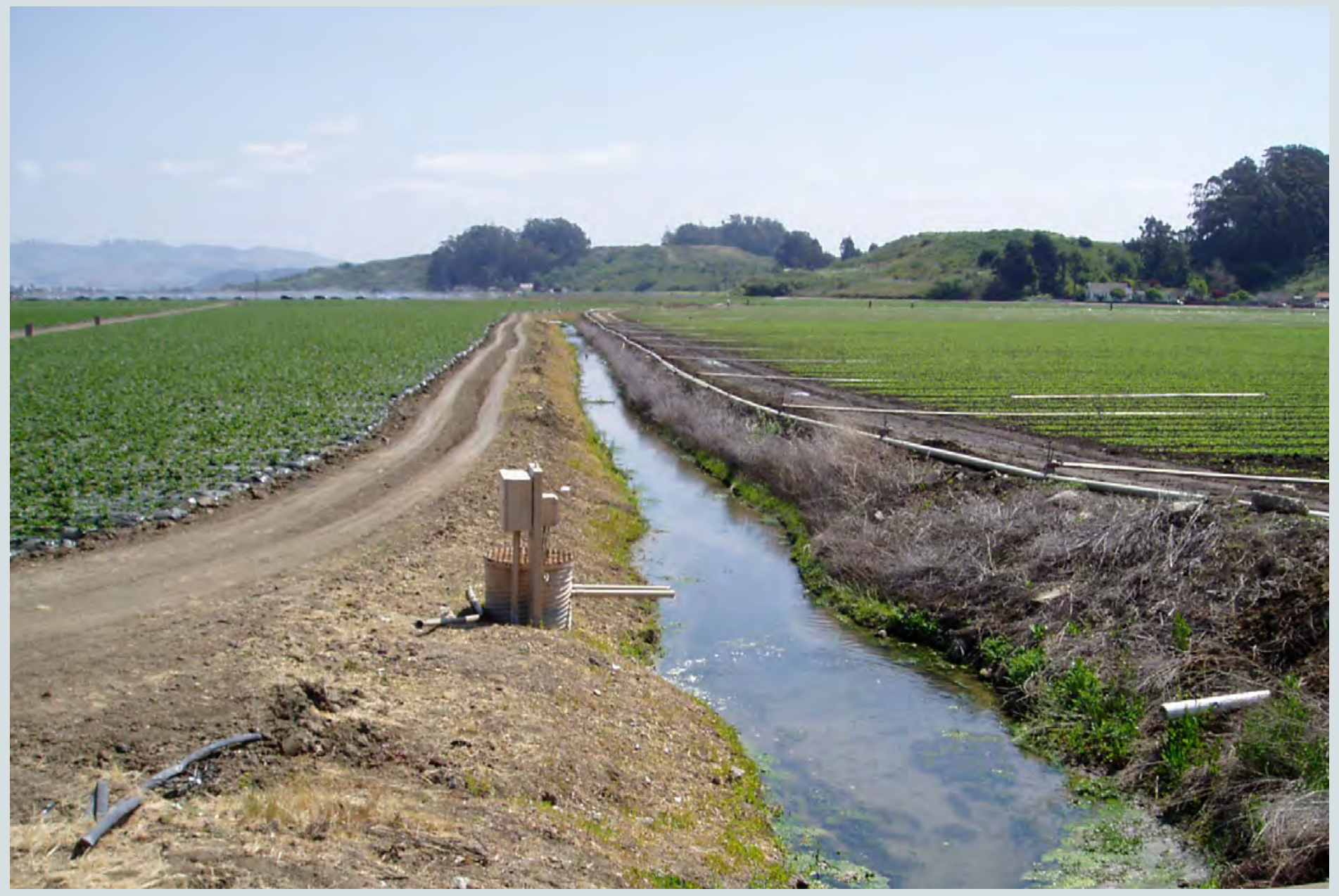

뮬

必

要.

앙 응

을 